Historic, Archive Document

Do not assume content reflects current scientific knowledge, policies, or practices. 



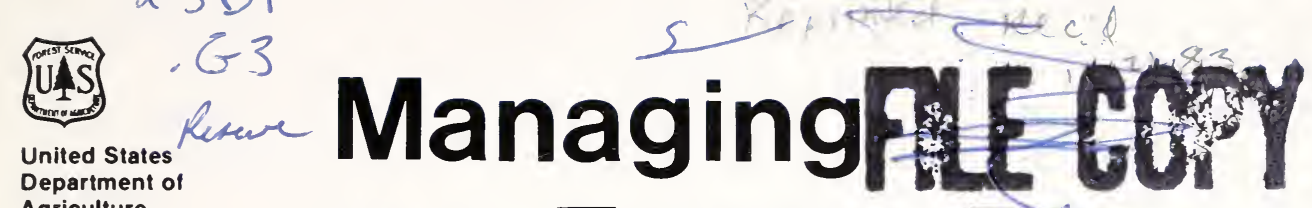
Agriculture

Forest Service

State \& Private Forestry

Southeastern Area
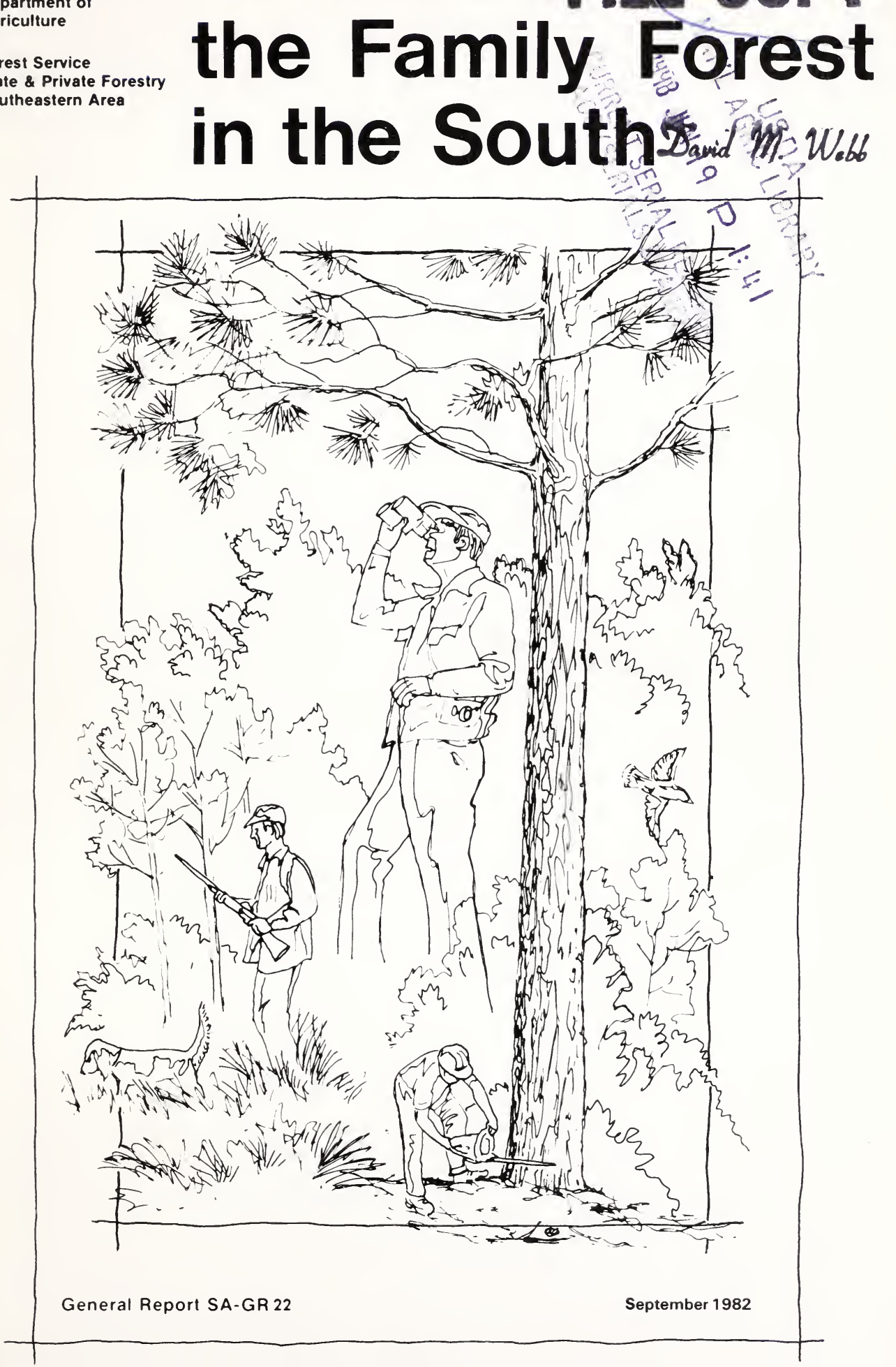
1 inch ..........................................................2.54 centimeters

1 foot 30.48 centimeters

1 pound 453.59 grams

1 acre 0.4047 hectare

1 board foot

$(12 \times 12 \times 1$ inch thick,

without bark, 1/4-inch Inter-

national Scale)

0.00348 cubic meter

The use of trade, firm, or corporation names in this publication is for the information and convenience of the reader. Such use does not constitute an official endorsement or approval by the U.S. Department of Agriculture of any product or service to the exclusion of others which may be suitable. 


\section{Managing the Family Forest in the South}

By

Hamlin L. Williston, retired; formerly Softwood Management Specialist

William E. Balmer, retired; formerly Forestation Specialist

Daniel H. Sims, Hardwood Management Specialist

USDA Forest Service

Southeastern Area

1720 Peachtree Road, N.W.

Atlanta, GA 30367 
Introduction

Regenerating the Forest................................................................ 2

Natural Regeneration................................................................ 3

Management Systems for Naturally Regenerating Pine... 3

Seeding Characteristics of Southern Pines .......................... 8

Site Preparation.................................................................. 9

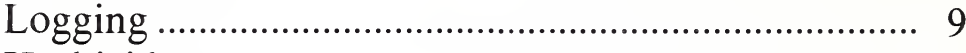

Herbicides ................................................................. 9

Prescribed Burning ......................................................... 10

Chopping, Disking, and Dozing .................................. 10

Advantages and Disadvantages of

Naturally Regenerating Pine....................................... 10

Natural Regeneration Guide...................................... 12

Planting the Southern Pines .................................................. 14

Five Crucial Phases ........................................................ 14

What Trees to Plant - and Where ............................. 14

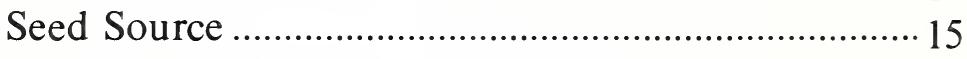

Insects and Diseases ................................................... 16

What is a Quality Seedling? ......................................... 18

Transporting, Handling and Storing Seedlings......... 18

Site Preparation............................................................... 19

Planting Seedlings................................................................. 21

Planting Methods....................................................... 21

Hand Planting .................................................................. 23

Planting Time............................................................... 23

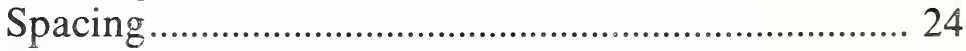

Machine Planting .......................................................... 25

Planting Follow-up ..................................................... 26 


\section{TABLE OF CONTENTS, Continued}

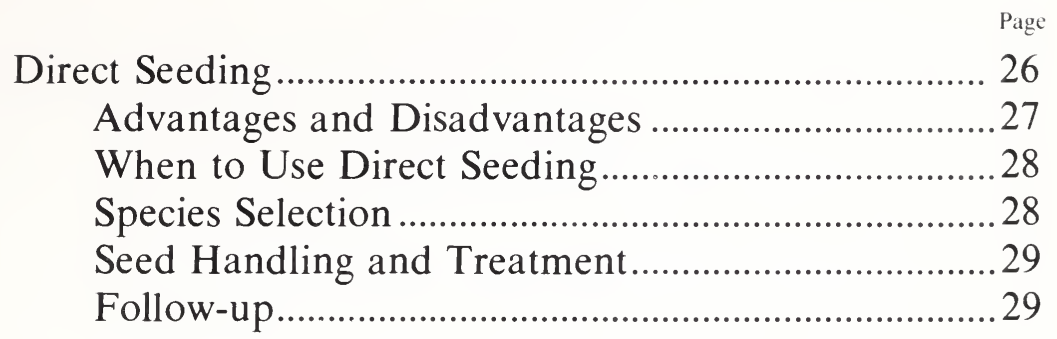

Regenerating Hardwoods Naturally.....................................30

Sources of Regeneration ...............................................30

Cutting Methods .............................................................. 31

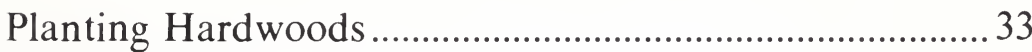

Intermediate Cultural Treatments for Pine ..................................34

Precommercial Thinning........................................................34

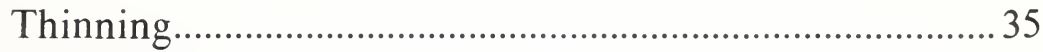

Pine Release Cutting ................................................................ 36

Improvement Cutting ........................................................... 38

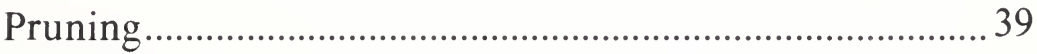

Hardwood Control Techniques................................................ 39

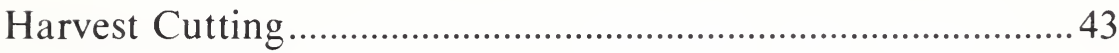

Intermediate Cultural Treatments for Hardwoods....................45

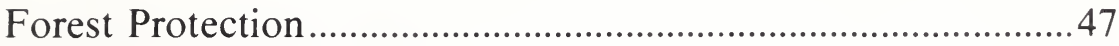




\section{TABLE OF CONTENTS, Continued}

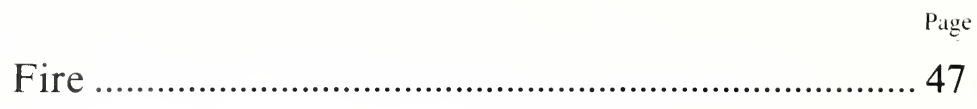

Insect and Disease Damage........................................... 48

Managing for Multiple Use .................................................. 53

Wild life Habitat Improvement...................................... 53

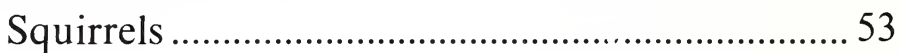

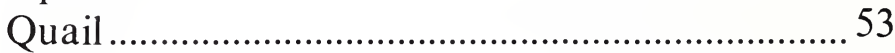

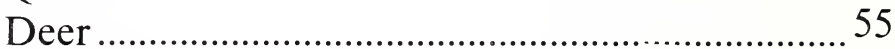

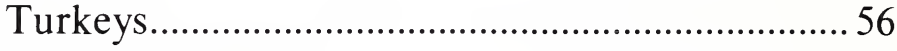

Nongame Birds ..................................................... 57

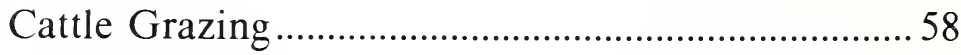

Watershed Management in the Forest........................59

Recreational Opportunities...........................................62

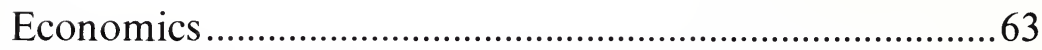

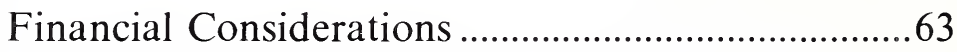

Tax Considerations ........................................................66

Marketing the Forest Crop....................................................68

Where To Go For help ......................................................... 83

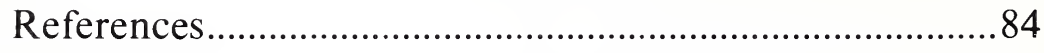

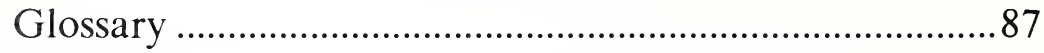




\section{INTRODUCTION}

Many of our forefathers came to this country because it offered an opportunity to own land. This desire is still inherent in many farmers and other private individuals who own 73 percent of the 192,542,000 acres of commercial forest land in the South. The practice of forestry on these holdings offers individuals something that can be both financially and spiritually rewarding and, at the same time, contribute to the local and national economies.

Many small woodlands are on highly productive sites and are close to good markets. However, the net annual growth on these forested acres reached only 56 percent of their potential growth rate, in 1970. This finding suggests that most landowners are not fully managing their forest resources.

To some, forest management means only management for timber production. However, in its broadest sense, forest management means management of forested acres for the continuous production of goods and services such as wood, water, wildlife, forage, and recreation. Owners should assess their own objectives so that their management plans will meet these objectives. The following pages describe how to increase timber yields, improve wildlife habitat, protect watersheds, obtain greater enjoyment from owning land and, in certain circumstances, use the forest forage. Sound forest management involves these steps:

- Locate and mark property boundaries and corners. Get technical advice, if needed

- Develop a forest management plan with the help of a professional forester

- Draw up, and follow, a schedule of forest practices

- Provide for fire protection 
- Sell only marked or designated timber

- Get technical assistance when making timber sales

- Use a timber sales contract when selling timber or other forest products

- Take advantage of cost sharing assistance

- Supervise cultural operations

- Check the forest periodically for insect and disease problems

- Acquaint your whole family with the forest

- Keep good records on costs and returns

- Enjoy your ownership and the practice of good forest resource management.

If you follow these steps faithfully a whole new world will open up to you and your family. The following pages describe sound forest management practices in detail.

\section{REGENERATING THE FOREST}

The best time to plan on regenerating a stand of trees is before harvest. Unfortunately, 5 out of 6 acres of forest land harvested in the South are not regenerated adequately by natural means, by planting, or by seeding. The end result is usually a tract of land with little or no reproduction of desirable species. "Accidental" forestry seldom pays good dividends.

Before harvest, you should decide on the species desired, the methods of regeneration and the timing of treatments to fully reforest the land. 
Two regeneration alternatives are open to landowners. The first alternative is to manage for natural regeneration through planned cultural practices. Secondly, you may wish to harvest completely, and follow up with planting or seeding to establish the new forest.

\section{NATURAL REGENERATION}

Natural regeneration involves more than simply letting nature take its course. Forests must be carefully managed for effective natural regeneration. If this is not done, the time lag between harvest and the establishment of a new crop of trees could mean economic suicide. Excessive numbers of seedlings could require expensive precommercial thinning, wiping out any savings in planting cost. A scarcity of new tree seedlings could under-utilize the planting site, robbing the owner of potential returns from the land. Effective natural reforestation is seldom free; it does not "just happen."

\section{MANAGEMENT SYSTEMS FOR NATURALLY REGENERATING PINE}

If you decide to use natural regeneration for pines, a variety of all-aged and even-aged management systems are open to you.

After removing most of the poor quality trees in your stand. you may still have a good stocking of vigorously growing pine over much of the acreage. Therefore, you may want to manage for an all-aged forest. Do this by periodically harvesting groups of trees, creating openings for natural regeneration. The result, in time, is a mosaic of groups or small stands of different aged trees.

If you want to use even-aged management (all trees in a given area are regenerated at the same time), at least five methods are available:

1. Seed tree is the most frequently used natural regeneration method in even-aged management. The number of seed 
trees left depends upon size, species, cone-bearing characteristics, and site conditions. See figure 1. The recommended number of well-distributed seed trees for five species of pines is given in table 1 .

2. Clearcutting in strips enables you to make periodic harvest cuts while managing even-aged units. The clearcut strips may be of any length, but preferably about 200 feet wide. Strips should be perpendicular to the direction of prevailing winds to ensure good seed dispersal. See figure 2.

3. Shelterwood entails leaving many seed trees. Usually, about 25 to 40 square feet of basal area are left per acre, depending upon the species. This is the equivalent of 23 to 37 14-inch trees (diameter at 4.5 feet) per acre. See figure 3.

4. Seed-in-place involves clearcutting the stand after the peak of seed fall, but before the start of germination. This method is best applied during a 4- to 5-month winter log-

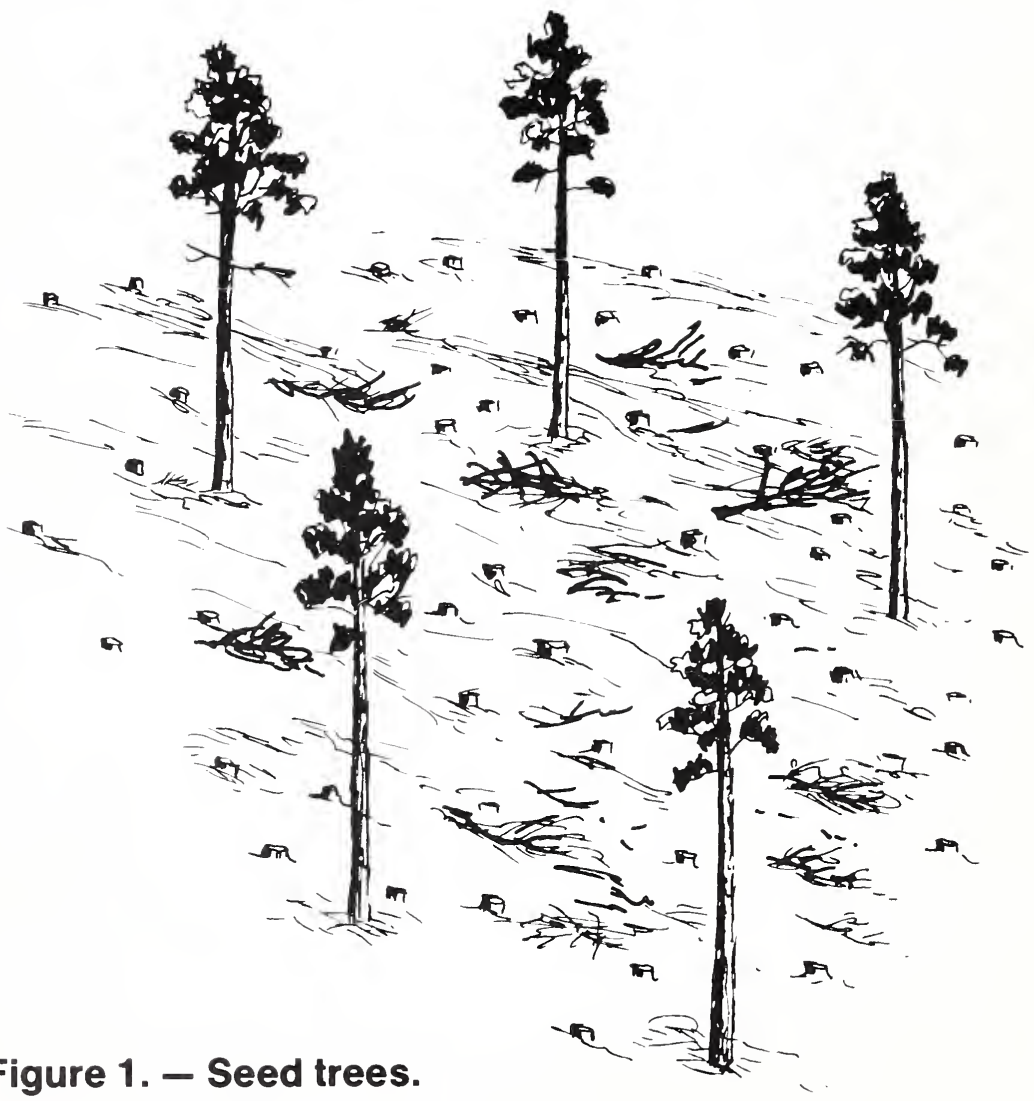


Table 1. - Minimum recommended number of seed trees, for pine species.

\section{D.B.H.' Shortleaf Loblolly Slash Longleaf $^{2}$ Virginia}

$\begin{array}{cccccc}9 & & & & & 6 \\ 10 & 20 & 12 & 12 & 55 & 5 \\ 12 & 14 & 9 & 9 & 38 & 4 \\ 14 & 12 & 6 & 6 & 28 & 4 \\ 16+ & 12 & 4 & 4 & 21 & 4\end{array}$

Diameter of trunk in inches at breast height ( $4 \frac{1}{2}$ feet above ground). 


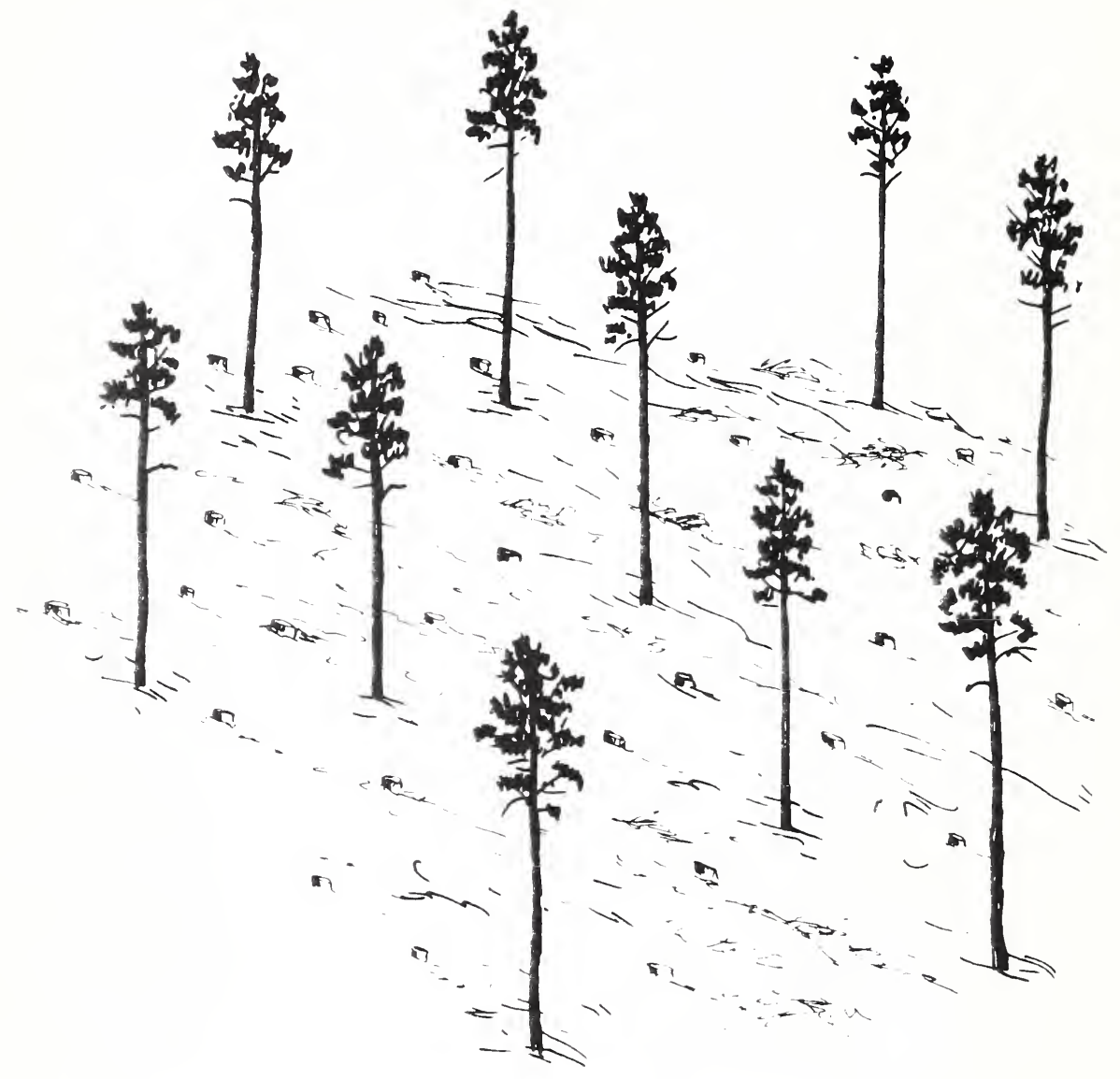

Figure 3. - Shelterwood.

ging period. As with the seedlings-in-place method (described below) this technique can be used only when an ample crop of seed is available. See figure 4.

5. Seedlings-in-place involves clearcutting a stand during the summer following a good seed year. See figure 5. Using th is method, you will lose some height growth when compared to the seed-in-place method because seedlings spend most of the first growing season in the shade of the overwood. However, the loss in height growth may be offset by additional volume growth of harvested trees. With the seed- 
lings-in-place technique, you can be more certain of having a satisfactory actual number of seedlings following germination of the fallen seed.

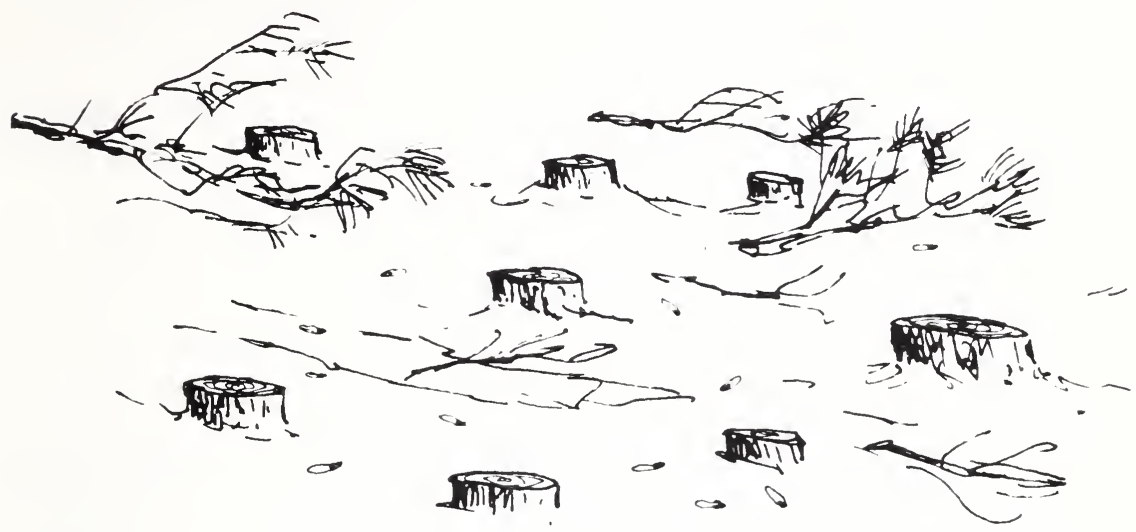

Figure 4. - Seed-in-place.

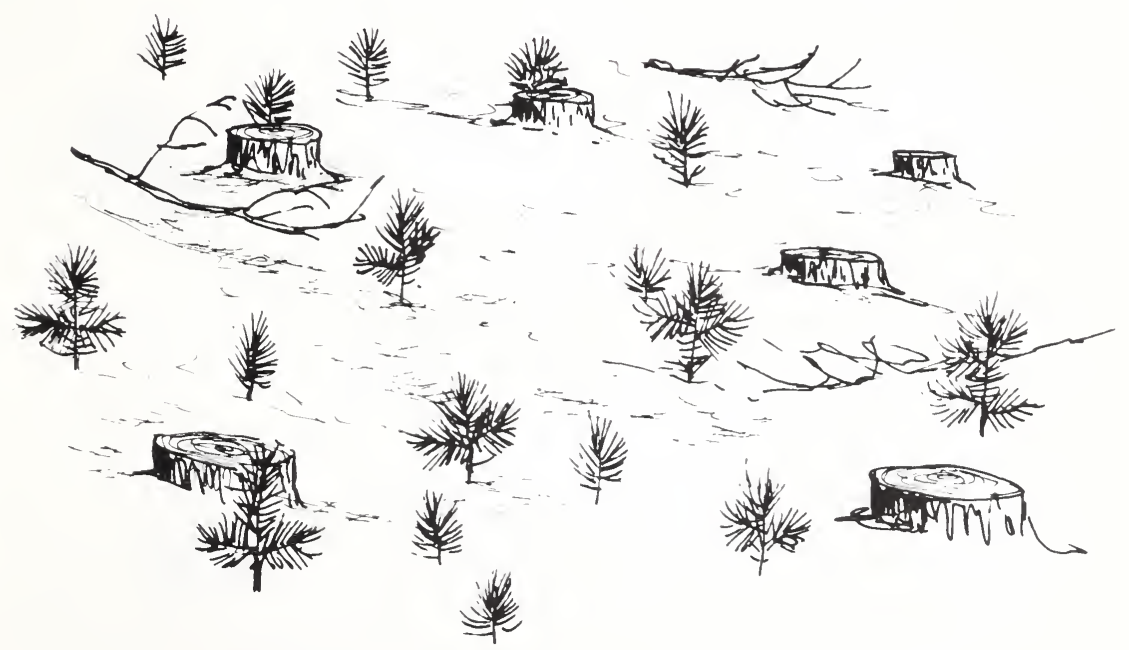

Figure 5. - Seedling in place. 


\section{SEEDING CHARACTERISTICS OF SOUTHERN PINES}

Seeding characteristics of the southern pine species vary with the area, species, weather conditions, and other factors. The landowner, with the guidance of a professional forester, must estimate the best time to catch and utilize a seedfall. Here are a few points to consider:

1. Loblolly, Virginia and shortleaf pines are the most dependable seed producers. Trees that have an adequate growing space usually will produce an adequate seed crop at least every 2 or 3 years. Cones of the major species of southern pines are shown in figure 6 . The number of seed trees needed for a good crop of seed from pines is shown in table 1.

2. Longleaf pine is not a prolific seed producer. Its large seeds appeal to a host of predators, including squirrels, birds, and mice. A carefully selected stand, 30 or more years of age, with a density of about 30 square feet of basal area per acre, produces usable crops at about 3-year intervals on average sites.

3. Slash pine seeds are generally produced on 3-year cycles, although some are borne almost every year.

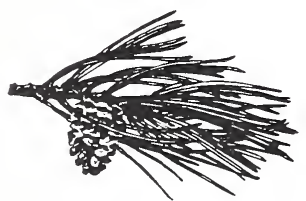

Slash pine

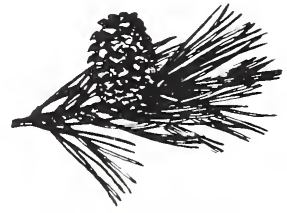

Loblolly pine

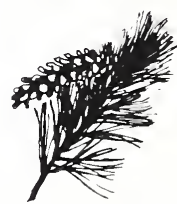

White pine
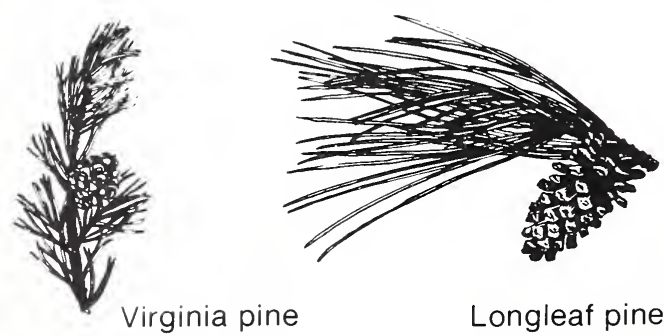

Longleaf pine

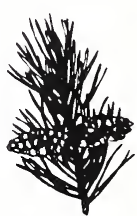

Shortleaf pine

Figure 6. - Cones of each of six species of pine. 
4. About 50,000 seeds per acre is the minimum needed to restock a prepared seedbed.

5. When selecting seed trees, remember that pine pollen is not carried in effective quantities farther than 300 feet.

6. The range of longleaf seed flight is only one and one-half times the tree height. Effective dispersal by wind of loblolly and shortleaf pine seed is about 200 feet.

7. Releasing seed trees from competition usually stimulates a substantial increase in seed production by the third year following release.

\section{SITE PREPARATION}

Site preparation is generally desirable for natural regeneration. Longleaf and slash pines in particular require a seedbed of exposed mineral soil to achieve a satisfactory restocking of seedlings. The types or combinations of site preparation needed depend upon the expected seed crop and the species of pine. An important point to remember is that most natural pine regeneration in the South has resulted in too much stocking, not too little.

\section{Logging}

In some cases, soil disturbance occurring during the logging operation is sufficient to provide a good seedbed.

\section{Herbicides}

If hardwood competition is moderate, aerial or ground application of herbicides can be done within 1 to 3 years after logging. Assuming only one treatment for release from hardwood competition is needed, the cost should run about $\$ 15$ to $\$ 25$ per acre. Herbicides reduce sprout development. allowing pine regeneration to become established within 2 to 3 years, without severe competition. If necessary, treatments may be repeated 3 to 4 years after pine seedlings are established, to keep hardwood competition in check. 


\section{Prescribed Burning}

Two or more annual burns before harvest provide good seedbed conditions and a high degree of hardwood control. A single burn following harvest has the same result, but there is always the danger of burning up the seed trees if logging slash (broken limbs and other debris left after harvest) is unusually heavy. To minimize seed tree damage, remove all slash near seed trees. The after-harvest burn should be carried out no sooner than 2 months before seedfall. The area should be checked before burning, to be sure that adequate seed or seedlings are not already present.

Prescribed burning is a good tool for site preparation and, at the same time, improves wildlife habitat. Burning sets back woody plants, making new sprout growth available for deer. Burning also stimulates seed germination and growth of valuable herbaceous plants, making their seed more available to birds by removing litter accumulation.

\section{Chopping, Disking and Dozing}

Limit the use of heavy machinery to the more difficult sites - those with extensive hardwood or other plant competition, to sites with a dearth of seed trees, or those that are extremely dry - or sites with hard-to-regenerate species. If precautions are not used, too dense a stocking may result. In dozing, a shearing blade is preferable; unless skillfully used, the straight blade or root rake removes too much topsoil, reducing site quality. Chopping, combined with a herbicide and/or burning, generally will suffice.

\section{ADVANTAGES AND DISADVANTAGES OF NATURALLY REGENERATING PINE}

When compared to clearcutting and planting, natural regeneration has numerous advantages and disadvantages. The advantages include: 
- Lower establishment cost

- Less labor and heavy equipment required

- No problem with geographical origin of seed

- Reduced tip moth damage

- Better early root system developed by natural seedlings

- Selection management more practical with this system

- Less immediate visual impact

- Less soil movement

The disadvantages include:

- Less control over spacing and initial stocking

- Longer rotations needed

- Risk of seed tree loss

- Generally lower yields

- No use of genetically improved or disease resistant stock

- Loss of a year or more of growth because of failure to regenerate promptly

- Need for precommercial thinning in many stands to obtain good growth

- Limited use in pulpwood rotations because of low seed production from dense, young stands 
- Irregular stands are not well suited for mechanical harvesting

- Poor access for fire equipment

\section{NATURAL REGENERATION GUIDE'}

\begin{tabular}{lll}
\hline \multicolumn{1}{c}{ Situation } & \multicolumn{1}{c}{ Species } & \multicolumn{1}{c}{ What to do } \\
\hline $\begin{array}{l}\text { Well-stocked stand, } \\
\text { to be managed }\end{array}$ & $\begin{array}{c}\text { Loblolly, shortleaf } \\
\text { and slash pine }\end{array}$ & $\begin{array}{l}\text { Starting at leeward } \\
\text { side clear-cut strips }\end{array}$ \\
while making period- & & about 200 feet wide. \\
ic cuts. & Burn strips after \\
& the fuel is cured and \\
& before next seedfall.
\end{tabular}

Well-stocked stand, Loblolly, shortleaf Use seed trees. to be managed in and slash pine even-aged units. Periodic cuts not For loblolly, seedrequired in the immediate future in-place and seedling-in-place also can be used.

\begin{tabular}{|c|c|c|}
\hline $\begin{array}{l}\text { Well-stocked stand; } \\
\text { owner wants to } \\
\text { manage forest as } \\
\text { all-aged units } \\
\text { while making per- } \\
\text { iodic cuts. }\end{array}$ & $\begin{array}{l}\text { Loblolly and } \\
\text { shortleaf pine }\end{array}$ & $\begin{array}{l}\text { Harvest groups of } \\
\text { trees periodically } \\
\text { to create openings } \\
\text { for regeneration. } \\
\text { May be able to pre- } \\
\text { scribe burn for } \\
\text { seedbed site prepar- } \\
\text { ation in some cases. } \\
\text { Treat hardwood brush } \\
\text { or inject unwanted } \\
\text { trees, as needed, with }\end{array}$ \\
\hline
\end{tabular}

Intended only as a quick checklist. In many cases. you have more than one alternative: decisions must be made based on the individual site and the owner's preferences. 
Mature, slow-growing, or sparse pine stands.
Loblolly and shortleaf pine

Cut back to seed trees. Burn before seedfall in a good year. Remove seed trees when the young pines are 1to -3 years old.
Understocked or mature stand.
Longleaf pine

Cut back to shelterwood of 30 square feet of basal area per acre. Remove when seedlings are established.
Stands of seedbearing size.

\section{Virginia pine ${ }^{2}$ Use even-aged management only. Clearcut in alter- nate or progressive strips using seed trees for final strip.}

Scattered sawlog pine. Heavy understory of hardwood brush.
All pine species. Chop and burn when debris is dry, or spray with herbicides in May or June. Burn in late August or early September.

\footnotetext{
${ }^{2}$ Grow Virginia pine only for short rotations because of its limbiness and susceptibility to heart rot. Avoid thinning it because of potential wind and ice damage. Under some conditions, light thinnings starting at an early age may be used to develop a sawtimber stand. If large products are desired and the site is good. consider conversion to other species.
} 


\section{PLANTING THE SOUTHERN PINES}

Most of the successful regeneration of southern pine is accomplished by planting seedlings. Planting, however, is not without it's pitfalls. Success depends on these steps: Combine the right species with the right site to achieve the best growth and survival; plant at the right time; follow time-proven steps throughout the planting process. Following recognized guidelines is important to the land manager, professional forester, vendor, or any landowner who plans to invest in tree planting.

\section{Five Crucial Phases}

1. Obtain professional advice for local conditions.

2. Choose the right species and the best adapted geographical seed source.

3. Plant quality seedlings.

4. Protect seedlings from excessive heat and loss of moisture, from the time you get them from the nursery through all steps in planting.

5. Plant trees in the proper manner.

These are five crucial links in the tree-planting chain. Ignore any one of these links and you will unnecessarily risk your investment.

\section{What Trees to Plant - And Where}

The next decision is to select the tree species. Your choice will depend to some extent upon the soil and location of the planting site. Remember, the biggest mistake made in tree 
planting has been to plant the wrong species on the site to be regenerated. See figure 7 for general guidelines for planting pines.

\section{Seed Source}

After choosing the species, the seed source must be considered. If the wrong seed source is used, profits may be reduced or disappear because of poor survival or slow growth of the seedlings. Seedlings bought in one State may - or may not - grow successfully in another State. Before considering such a step, check a seed source guide.

Select the species best suited for the site, to produce the desired product(s) within an acceptable rotation length. Remember, if Virginia pine or sand pine are planted, pulpwood will likely be the principal product.

Genetically improved seedlings are being produced in steadily increasing numbers; consider their use when possible.

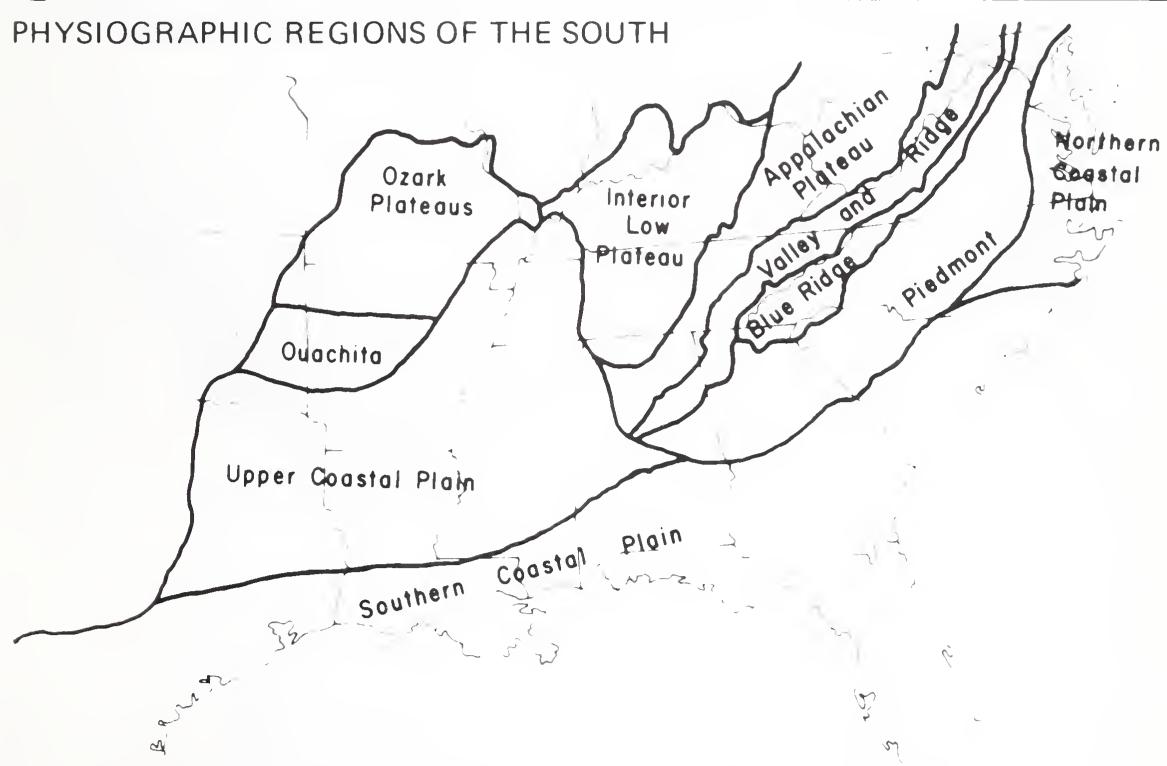

Figure 7. - Species-site guide for planting southern pines. 
Improved seedlings can be expected to increase yields, as well as improve the quality of the wood and resistance to disease.

\section{Insects and Diseases}

Fusiform Rust. - This is the most important disease of loblolly and slash pines. In areas where fusiform rust is a problem, consider planting rust resistant stock. You may also choose species least susceptible to rust, such as longleaf, shortleaf, Virginia and white pine. Cultivation and fertilization increase growth in slash and loblolly pines, but also increase their susceptibility to fusiform rust.

Littleleaf Disease. - This is a major problem with shortleaf pine and, to a lesser extent, loblolly pine in Alabama, the Piedmont of Georgia, North Carolina, South Carolina and Virginia, as well as parts of Mississippi and Kentucky. See figure 8. Until disease-resistant planting stock is available, favor loblolly pine in areas where littleleaf disease is a problem.

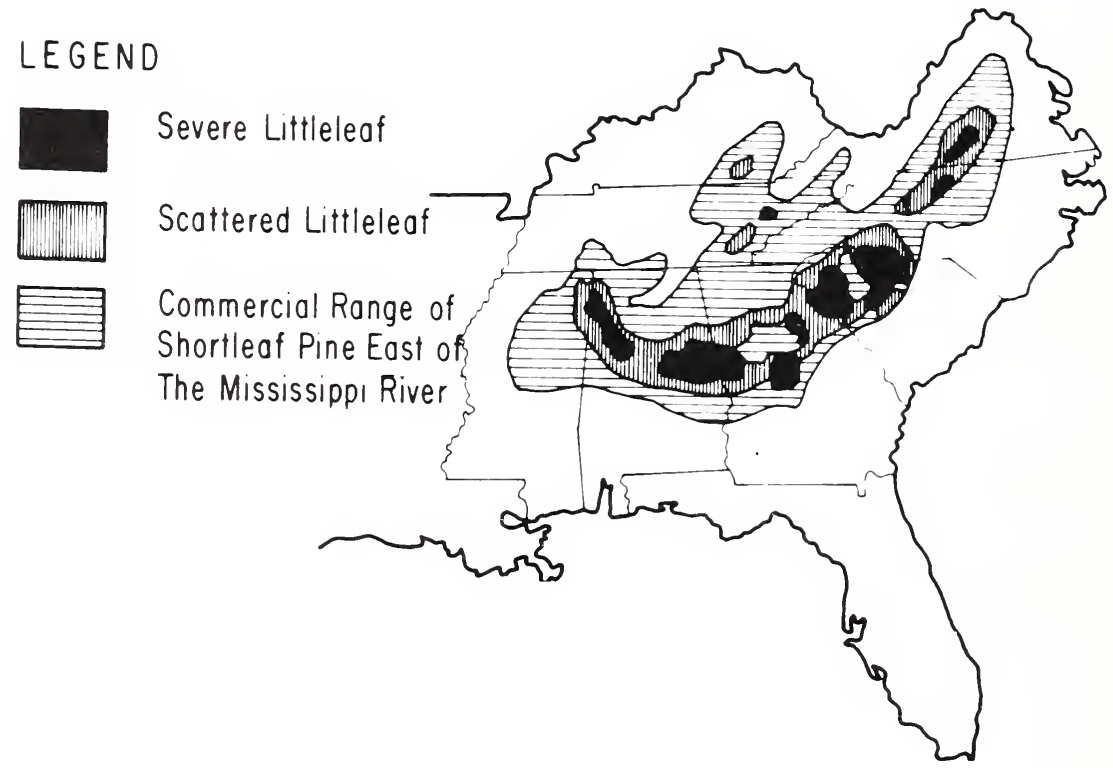

Figure 8. - Areas where littleleaf disease of pines are most likely to be a problem. 
Annosus Root Rot. - This disease kills many trees in thinned stands, in some areas. High-hazard sites are those with 12 inches or more of sand over heavy clay. Low-hazard sites have poor internal soil drainage, high seasonal water tables, or a depth to clay less than 12 inches. The disease is more common and severe on old-field sites. Preventive measures on high-hazard sites include planting at a spacing wider than 8 by 8 feet to reduce frequency of thinning; sprinkling powdered borax on fresh stump surfaces; and, in locations south of 34 degrees north latitutde ${ }^{3}$, thin your stands during the hottest months (May through August) except when bark beetles are a potential problem.

Brown Spot Disease. - This can be a major problem with longleaf pine, particularly in areas from southwestern Alabama to the western tip of the longleaf range in Texas. A prescribed fire is a good way to control brown spot in plantations if infections are heavy. Brown spot resistant strains of longleaf pine are being developed and should soon be available.

Southern Pine Beetle. - This insect has killed many pines throughout much of the South. The beetle attacks loblolly and shortleaf pine stands that are under stress from drought, overstocking, poor drainage, disease, storm damage, or logging damage. Good stand management offers the cheapest, most practical, and longest lasting means of control, especially where beetle epidemics occur frequently. Recommended preventive measures include matching site and planting stock; thinning overstocked stands; promptly salvaging lightning-struck, diseased or damaged pines. Plant resistant species such as longleaf and slash pines; take care in the use of equipment in forests, including road construction; and when harvesting all mature trees.

Pales Weevil - This is the worst insect pest of pine seedlings on recently cutover pine lands. In problem areas, apply an insecticide if suitable chemicals are registered for this use in your State (check with your State forestry agency for current information). Otherwise, delay planting for one season

'Includes most parts of the Gulf States, Georgia, South Carolina, lower part of Arkansas, and southeastern North Carolina. 
following harvest cutting. If the southern pine beetle is a problem in your area, consider planting slash pines rather than loblolly, within the natural slash pine range.

\section{What is a Quality Seedling?}

A quality seedling is one that is easily planted, disease free, and meets the following standards:

- Root collar diameter: No less than $1 / 4$ inch for longleaf pine and $1 / 8$ inch for others.

- Stem: Stiff and woody with secondary needles present.

- Top length: Maximum of 14 inches for all species.

- Root systems: No less than 5 inches nor more than 9 inches long.

\section{Transporting, Handling and Storing Seedlings}

Once a quality seedling is produced at the nursery, only half the battle is won. From the time a seedling is lifted from the nursery bed until it is safely planted in the field, the greatest danger to its life is too much root exposure to the sun, wind, or just dry air. Do not expose roots to the sun or wind for more than 10 minutes.

Avoid hauling seedlings for long distances in open trucks, particularly in warm weather, to prevent overheating and drying. Freezing can also kill seedlings. Heavy damage can result if seedlings are separated while they are frozen. If time is a factor, immerse frozen bales in cool water before separating the seedlings.

After receiving seedlings from the nursery, immediate planting is not always possible, so some method of storage must 
be planned. Whatever the method used, stickers ( 1 by 2 inch or wider boards) must be placed between stacked packages to allow air to circulate and prevent heating.

Cold storage is the best method. Dormant seedlings can be held at temperatures from $32^{\circ}$ to $40^{\circ} \mathrm{F}$. for as long as 10 weeks if packed in standard Forest Service bales, and 12 weeks if in kraft-polyethelene (k-p) bags. Plant non-dormant stock first.

If cold storage facilities are not available. seedlings may be stored in a warehouse or on shaded racks, but the seedlings will need special attention. If seedlings are packed in standard Forest Service bales with wet media, watered upon receipt and bi-weekly thereafter, they can be stored up to 8 weeks. At the same time. they must be protected from heat and subfreezing temperatures. If seedlings are packed with a clay slurry dip, no watering is needed. If packed in k-p bags, seedlings can be stored up to 8 weeks, provided they are encased in wet packing or a clay slurry dip. Otherwise, 4 weeks is the maximum storage time. K-P bags should not be watered.

Plant sand pine seedlings within 1 week after they arrive from the nursery. Bales or packages of sand pine seedlings should not be stacked in storage.

\section{Site Preparation}

In some cases, it pays to reduce or eliminate competing vegetation before planting. Weigh the initial costs of treatment against future returns. Too intensive a treatment may be uneconomical, even though an increased volume results. Too intensive a treatment may actually decrease site productivity. On droughty soils with limited organic material, intensive site preparation may increase survival at the cost of later growth. Ideally, site preparation reduces competition without removing or destroying top soil and organic matter.

Disking and furrowing are most successful where heavy sod is present. When performing these operations:

1. Do not plant in furrows where the water table is close to the 
surface. Water standing in the furrows or very close to the surface inhibits root growth and may kill the seedlings.

2. Do not furrow light sandy soils. Survival usually is improved but, because top soil is removed, long-term growth may lag.

3. Always install furrows on contours to reduce erosion. For the same reason, avoid disking slopes of 10 percent or more.

In light sod, disking and furrowing are not usually needed. A scalper on the tree planter removes grass competition and clears trash from its path in one operation.

A rolling drum chopper can effectively reduce woody competition with minimal soil disturbance. Larger choppers are usually more effective than small ones; two choppers in tandem are more effective than one. If trees are scattered or too large to chop, treat them by other methods.

Shearing or KG blading is often the best way to remove large numbers of stems that are too large to disk or drum chop. With care, little soil is disturbed and most debris that would hinder planting is removed. If debris is piled in windrows, allow frequent breaks for access by planting equipment and firefighting equipment. Large piles and windrows of debris deteriorate slowly. They also occupy more planting site and result in greater loss of top soil through pushing of material farther across the ground. Keep the aisles and windrows as narrow as possible. Hand planting usually eliminates the need to windrow or pile debris.

Rootraking and bulldozing can also be used to remove trees and shrubs. Disadvantages of these techniques include excessive soil disturbance, and considerable topsoil ends up in the windrows.

Apply chemicals for individual stem treatment or on larger areas. No soil is disturbed and litter is not destroyed. When chemicals are used alone, machine planting is not practical unless hardwoods are very small.

Individual tree release is best suited to smaller tracts in areas of abundant labor. Release is usually accomplished immediately after planting, by injecting a herbicide or by fel- 
ling competing trees, with herbicide applied to the stumps.

Foliar use of herbicides by equipment on the ground or aircraft is usually the cheapest and fastest method of hardwood control. However, use these methods only when there is no hazard from drift. Be sure to contact your State forestry agency for the latest information on herbicide usage.

Prescribed fire is a valuable supplement to some forms of mechanical or chemical control of competing vegetation. Other benefits are improved access and visibility, which increase efficiency and safety of planting operations. Drum chopping and fire, used in combination, is one of the most effective and least destructive methods of intensive site preparation. Some drawbacks of prescribed fire are: local or State laws on smoke management may prevent burning during part of or all of the year, or on sites with minimal litter present; fires may be erratic when used alone; fire will seldom provide lasting benefits; and fire must be used skillfully for safe and effective results.

Caution: When conducting any practice that disturbs the soil, leave undisturbed strips along streambanks to filter out sediment. Strips should be 25 feet wide plus an additional 2 feet for each 1-percent increase in slope.

\section{PLANTING SEEDLINGS}

\section{Planting Methods}

There are two options: to plant by hand or with machines. If the site is a vast, open expanse, machine planting is by far the more economical method, enabling the same crew to plant four to five times more trees per day than in limited areas. Hand planting is more efficient on small areas, where the terrain is very rough, or where numerous stumps, debris or large diameter hardwoods impede the use of machines. See figure 9. 


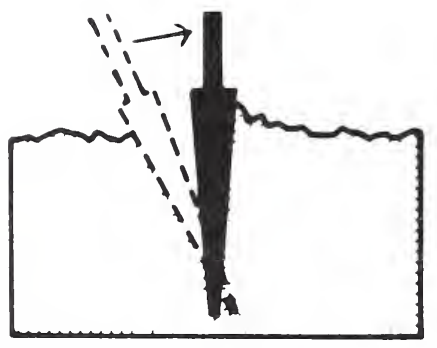

I. Insert dibble at angle shown and push forward to upright position.

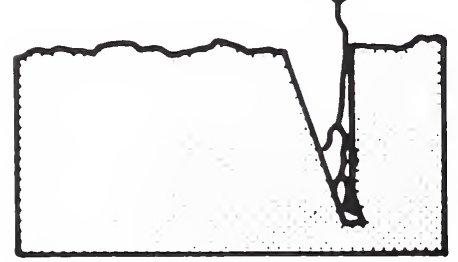

2. Remove dibble and place seedling of correct depth.

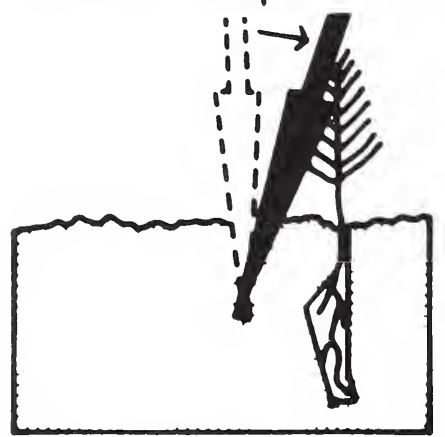

3. Insert dibble part way, push and twist forward closing top of planting slit.

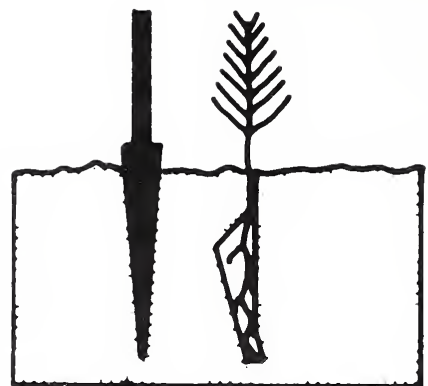

4. Push dibble straight down to depth of blade.

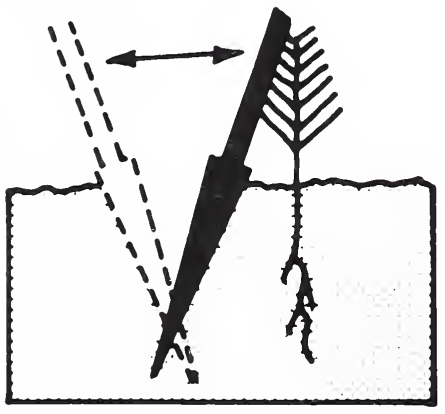

5. Rock dibble back and forth to pack soil firmly against root.

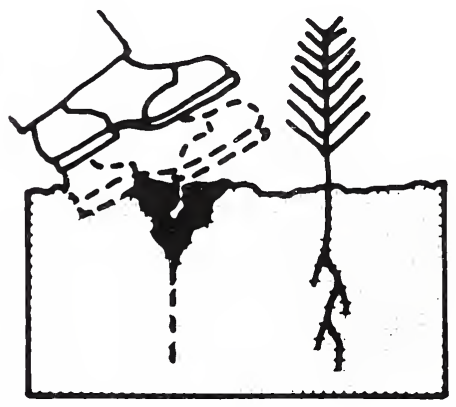

6. Fill in last hole by stamping with heel.

Figure 9. - Guide for planting southern pines. 


\section{Hand Planting}

Three tools are essential to the hand planter: (1) A dibble or planting bar; (2) planting bag for carrying seedlings; and (3) wire cutters, if seedlings are bound with steel straps. Figure 9 shows the procedures for hand planting:

1. Inset the dibble at an angle to the depth of the blade. Push the dibble forward to open the hole (don't compact the soil by rocking the dibble back and forth).

2. Remove the dibble and insert a seedling deeply in the hole, then withdraw the seedling until its root collar is at, or slightly below, the ground level and the roots are straight.

3. To hold the seedling in place, insert the dibble part way into the ground 2 inches behind the hole, then push and twist the dibble forward, closing the top of the planting slit.

4. Push the dibble straight down to the depth of the blade.

5. Rock the dibble backward and forward to pack the soil firmly against the root.

6. Fill in the last hole by firming it with your heel.

\section{Planting Time}

For conventional bare root seedlings, the most favorable time to plant is during the dormant season. (The season can be extended from 2 to 4 weeks by placing dormant seedlings in cold storage.) Avoid planting when the ground is hard - either frozen or dry - or when too wet or sticky. Planting when the soil is in poor condition results in low survival, poor planting production, misplanted seedlings, and poor growth. 


\section{Spacing}

Before ordering seedlings, decide what spacing to use. No standard spacing can be recommended because of differences in site quality, local survival pattern, products desired, or other factors. For most situations in the South, spacings of 7 by 9,7 by 10,8 by 8 and 8 by 9 feet ( 600 to 700 trees per acre) have many advantages over closer spacings because they:

- Are much cheaper (about half as many trees are needed with 8 by 9 foot spacing as with 6 by 6 foot spacing, for example).

- Produce about the same volume of wood in 20 years on fewer trees, increasing the end value.

- Enable you to delay a decision on the product objective pulpwood and/or sawtimber - without a large financial penalty. You can therefore hedge against market changes during the 15 or 20 years after planting.

At the same time, the advantages just described must be balanced against those of closer spacing which:

- Produce a greater volume of wood in the first 20 years.

- Provide more insurance against poor survival caused by poor site quality and losses from insects and diseases.

- Provide an opportunity for an early return from thinning.

- Produce a higher quality tree.

- Make better use of good sites.

One precaution: With any spacing, some rows should be spaced 10 to 12 feet apart at regular intervals to provide access for fire-fighting and harvesting equipment. 
Wider spacings may be desirable when you want to grow larger products as fast as possible, or to grow slash or longleaf pines for naval stores.

\section{Machine Planting}

Specific planting machines are not recommended because conditions vary throughout the South. Fortunately, a variety of good machines are available; one or more of them will be particularly suited to your area. See figure 10 .

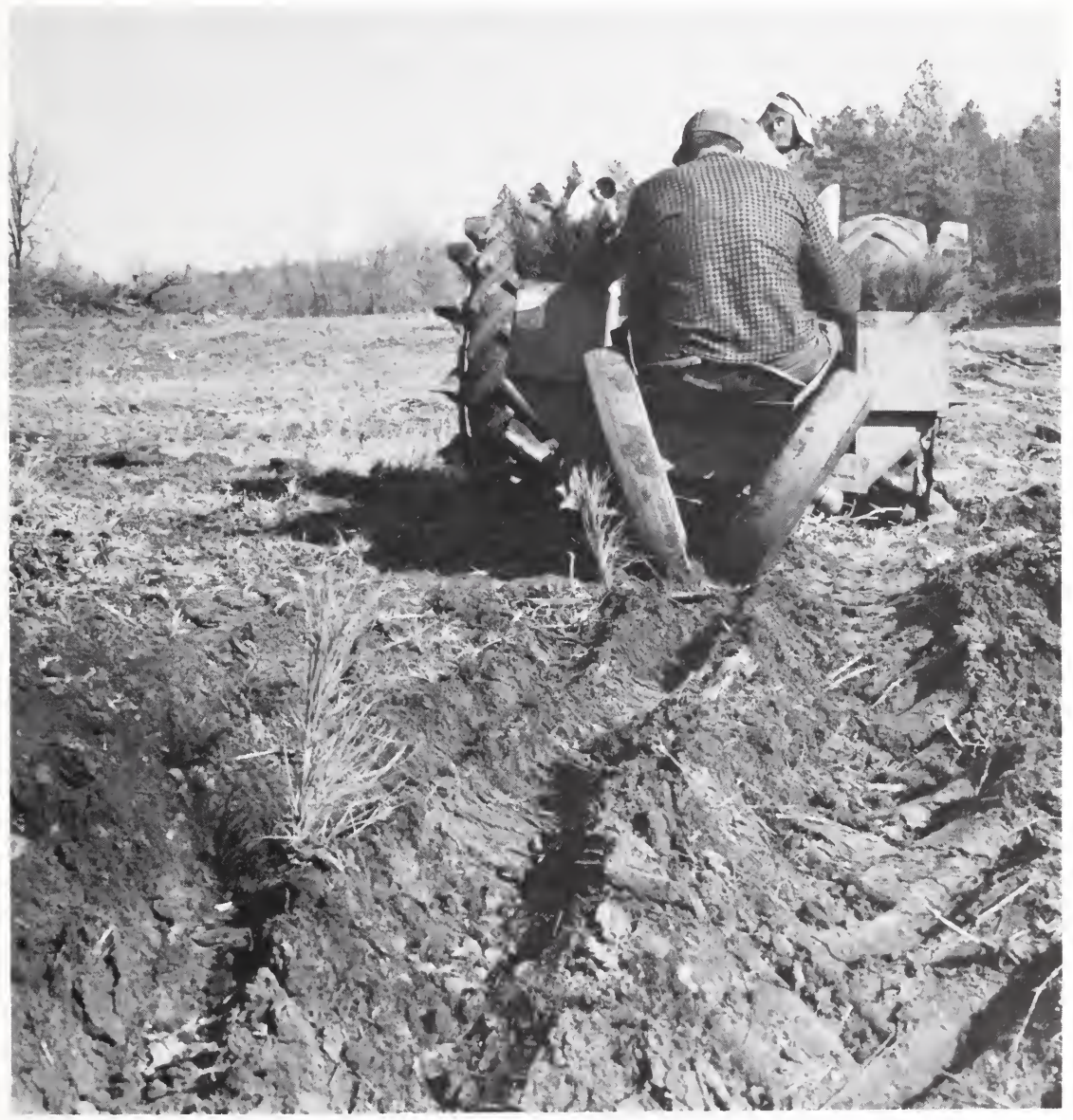

Figure 10. - Machine planting. 
Protecting seedlings from drying out during machine planting is just as important as it is when planting by hand. Keep the seedlings covered and the roots moist.

As in hand planting, check frequently to assure that the seedlings are being planted properly. Key points include: (1) proper depth of the trench; (2) correct tracking of the packing wheels; and (3) proper closure of the trench by the packing wheels. Check root placement by opening one side of the trench with a shovel to expose the seedling in place.

\section{Planting Followup}

To check survival, randomly select some planting areas to be sampled. In March or April following planting, grid each tract selected with ten $1 / 100$-acre plots (a circular plot with a radius of 11.8 , or a square plot 20.9 feet to the side). Mark the center of each plot with a stake, locate the plot on a map, and flag each planted seedling. In the fall return to the plots and count the surviving trees. Multiply the total by 10 to find the average seedling survival per acre.

As a rule, if 300 or more well distributed seedlings survive per acre, it does not pay to replant. If survival is less than 300 seedlings per acre and they are not well distributed, it may be best to clear the remaining seedlings and start over. Decisions to replant will vary, depending upon replacement costs and estimated stumpage values.

When checking survival, periodically re-evaluate the need for release of seedlings from competing hardwoods. Many plantations have survived well the first year, only to fail later because of overtopping competition.

\section{DIRECT SEEDING}

Direct seeding can be an effective practice for regenerating the southern pines. On many sites, direct seeding is more economical than planting nursery-grown seedlings or waiting for natural reproduction. Direct seeding may be the best choice on some sites where access, terrain, or drainage conditions make 
planting difficult. Discovery of effective bird, rodent, and insect repellents has made direct seeding possible and practical, although the process requires a high degree of technical skill and knowledge. The key to success lies in obtaining the advice and assistance of an experienced direct-seeder.

\section{Advantages and Disadvantages}

The choice of a method of regeneration depends on your goals and economic situation, as well as the capability and condition of the site. The advantages of direct seeding include:

- Lower initial costs

- May require less site preparation

- Less labor and heavy equipment needed than for planting

- Natural root system - no L, J, or W roots

- Easier to apply on remote or inaccessible areas

- Flexibility - may be able to regenerate quicker following fire or other disasters.

- Easier to regenerate large areas quickly

- Easier to regenerate some hard-to-plant species

Disadvantages of direct seeding include:

- Less control over spacing and stocking

- Longer rotations needed

- As a rule, lower yields 
- Little opportunity to use seed from disease-resistant or genetically improved sources

- Loss of a year's growth

- May need precommercial thinning

- Irregular stands not well suited for mechanical harvesting

- More difficult access for fire equipment

- Seed washing on steep slopes results in loss of seed or uneven distribution.

\section{When to Use Direct Seeding}

Increasing planting costs, a growing shortage of labor, the need for prompt restocking of forestland, and the sheer magnitude of the regeneration job facing the South make direct seeding worthy of consideration. Direct seeding can be used to regenerate open lands and, with site preparation, it is effective on land partly or wholly occupied by brush or low-value hardwoods. Generally, any plantable area is suitable for direct seeding. Exceptions include deep sands that dry rapidly, and excessively wet soils unless they are bedded. As a general rule, consider direct seeding if site preparation costs are low; plant seedlings if site preparation costs are high.

\section{Species Selection}

Choose the species that will meet your objectives: probably a species superior in growth and yield. In general, grow loblolly in the Piedmont and upper Coastal Plain where the terrain is rough and hardwood competition severe. Slash pine grows best in the southern Coastal Plain flatwoods; longleaf pine on areas where it formerly grew; shortleaf or Virginia pine in the northern reaches of the South that are too cold for loblolly; and sand pine on the deep sandy areas of Florida and south Georgia. 
Thorough site preparation is essential to expose the mineral soil that pine seeds need for germination, and to control competing vegetation that interferes with the survival and early growth of the new stands. Methods described under planting also apply to direct seeding.

\section{Seed Handling and Treatment}

All seed should be treated by trained workers to provide a high degree of protection from seed-eating birds, mammals and insects. Because some chemicals are toxic, directions for safe handling should be followed carefully.

Time of Year - Sow longleaf pine seed in the fall after natural seedfall, and when the soil moisture has been recharged by 2 to 4 inches of rain, or in the early spring. Sow loblolly, shortleaf, and slash pine seed in the spring about the time the first blooms appear on redbud and red maple. Normally, in the spring, prolonged periods of freezing weather are past, soil moisture is adequate, and daily temperatures reach levels needed for germination. Stratified seeds sown in mid-February usually complete germination by mid-April, though prolonged cool weather or drought can extend germination into May.

\section{Follow-up}

To be sure that adequate numbers of seedlings are present, make a field check at the end of the first growing season. A check early in the summer is also a good idea to determine germination success. The difference between the two inventories reflects the first summer mortality and will be useful information for seeding similar areas. To sample broadcast areas for a probable accuracy of \pm 20 percent. stake out a grid of 25 mil-acre plots (radius 3 feet. 8.7 inches). Count the number of seedlings on each plot and multiply the average by 1,000 to get the number of seedlings per acre. Stocking is the percent of mil-acres with at least one seedling present. When numbers per acre are between 1,500 and 3,500 the usual range of stocking is 
between 60 and 80 percent. A widely accepted minimum criterion for success is 55 percent. Should the stocking be less than 55 percent, wait another year and take another inventory before regenerating by reseeding or planting. Some areas have been seeded twice, unnecessarily. Eight out of 10 seedings are successful.

Areas with 2,000 or more seedlings per acre at the end of the first growing season should be reinventoried at age three. If there are then 1,500 or more live seedlings per acre, the area should be given a precommercial thinning promptly for yields to approach the yields from plantations. Some seeded areas may need release from hardwood sprouts by chemical sprayings.

\section{REGENERATING HARDWOODS NATURALLY}

\section{Sources of Regeneration}

On most hardwood sites, natural regeneration will be sufficient to replenish the stand. Go through a stand before the harvest cut to see if you can expect to have enough seedlings, seedling sprouts, root sprouts, or stump sprouts of the desired species to develop into an adequately stocked stand once the overstory is removed. Tolerance of species to shade, and whether the species is heavy or light seeded, will govern the steps to be taken to start a new stand.

Intolerant, light-seeded species such as yellow-poplar, ash, and cottonwood will regenerate themselves from seed if the seedbed conditions are favorable and sunlight is available. Seed from species such as yellow-poplar and ash remain viable on the forest floor for several years and are usually plentiful if these species were present before harvest. Also, birds, animals, and wind transport seeds from nearby stands. Logging activity is usually sufficient to scarify the forest floor and provide the mineral seedbed needed for germination. Removal of the overstory and brush will enable sunlight to reach the forest 
floor, helping the light-seeded species to germinate and grow fast enough to compete with other plants. Usually, seed trees need not be left on hardwood sites.

When regenerating heavy-seeded species of intermediate shade tolerance, such as the oaks, well established seedlings should be in the understory at the time of harvest. These seedlings develop after germination under the shade of the forest canopy. Many seedlings die quickly, others die back and resprout, but some endure under closed canopies for several years, and are called advance regeneration. Their top growth may be very slow, but the root system continues to develop.

Advance regeneration is particularly important for oaks because new seedlings are produced sporadically, and grow too slowly to compete successfully with other species. Oak saplings, 4 to 5 feet in height, with well developed root systems, are most desirable as advance regeneration. These young trees will respond quickly and vigorously to sunlight after the harvest cut, and should grow fast enough to compete with other species. Logging usually does not harm advance regeneration because sprouts will grow vigorously from the root collars of saplings and seedlings that are broken or cut during harvest.

Young hardwood stands almost always contain some stump sprouts, and occasionally entire stands can develop from stump sprouts. Because of their vigorous early growth, stump sprouts often dominate other forms of reproduction. The quality and longevity of trees resulting from stump sprouts are sometimes questioned, but stems that start from small stumps below or near the ground line are usually good risks. Stump sprouts from yellow-poplar often produce the best trees in the stand. Most hardwoods also produce root sprouts. Species such as black locust and sassafras produce them prolifically and may regenerate almost entirely from root sprouts.

\section{Cutting Methods}

The total removal of the canopy in one cut, called clearcutting, is an effective and efficient method to naturally regenerate a hardwood stand. Clearcutting provides the best 
conditions for fast-growing, shade-intolerant species that need full sunlight to develop rapidly. Some shade-tolerant species also do well under these conditions. Total canopy removal results in an even-aged stand.

The commercial timber harvest will remove much of the canopy - and the cleaner the logging job the better. In most cases, however, culls, low quality trees, undesirable species, and some small trees will be left. Cut or kill these remaining trees so they will not impede regeneration. You may control this unmerchantable material by several methods. A combination of felling and herbicide injection could be used. Trees of desirable species that produce sprouts could be felled, and undesirable species could be injected. Undesirable trees may be controlled before or after the commercial logging operation. The method and timing are less important than making sure that unwanted trees are treated, especially stems larger than 4 inches in diameter.

In some stands, grapevines may interfere with seedling growth. Grapevines are intolerant of shade and, if cut 3 to 4 years before the timber harvest, they should not be a problem in the new stand.

The size of the regeneration opening depends on your overall management objectives. Areas as small as $1 / 2$ acre can be used, but development of such small tracts will be impeded by side competition and over-browsing by deer. Also, such small tracts are inefficient to manage. Openings several acres in size usually can be managed more efficiently and with fewer residual trees affected by degrade on the edge of the openings.

Good hardwood regeneration has developed from the shelterwood regeneration method. A series of treatments are involved: (1) partly cut the overstory to leave 50 to 60 square feet of basal area per acre, (2) cut, or inject herbicide in the unmerchantable understory trees at the time of the first cut, (3) a few years after the first cut, make a secondary cut - which would be a final harvest cut if regeneration is satisfactory, or cut the stand back to 40 to 50 feet of basal area again if regeneration needs to develop further under shelter. In the latter instance, a third, final harvest cut would be made. 
The shelterwood method also produces an even-aged stand. The sources of regeneration can be the same as in a clearcut, but they depend somewhat less on seed and seedlings already in place before any cutting is done. In most cases, leaving a shelterwood has few biological advantages, but it can be used to help develop advance regeneration.

The shelterwood method of regeneration cutting should not be confused with the occasional removal of the biggest and best timber trees - or high grading. When you make partial cuts to regenerate a stand, treat unmerchantable understory trees, and remove the remaining overstory when regeneration reaches a satisfactory stage. High grading produces neither of these goals and badly detracts from long-range growth potential.

Removal of single trees scattered throughout the stand, as a regeneration method, generally has not proved to be an effective way to regenerate the hardwoods of the South. Most desirable southern hardwoods have little tolerance of shade. They will begin to develop under partial shade, but they should be released from overhead competition fairly early in life. The biggest drawbacks to single-tree selection are that the method fails to provide for quick and orderly removal of overhead competition and it promotes the development of shade-tolerant species, many of which are not desirable.

\section{PLANTING HARDWOODS}

Hardwood seedlings account for about 1 percent of the total seedlings produced in southern nurseries. The highest species production is for black locust, sycamore, cottonwood, eucalyptus, sweetgum, black walnut, yellow-poplar, green ash, white ash, and water-willow oak.

Black locust is planted primarily for erosion control. The rest are planted most often by industry on clean tilled land where they are cultivated two to four times during each of the first 2 years in the field. 
Black walnut and yellow-poplar are the two preferred species for planting on small ownerships in the Piedmont, the extreme upper Coastal Plain and farther north. Both species are quite site specific. Fastest growth occurs on stream terraces, in coves, and on lower north- and east-facing slopes. The soil should be deep, fertile, and well drained. If yellow-poplar trees of seed bearing age were present in the harvested stand, then planting is usually not necessary.

Hardwood seedlings should be large, with a root collar diameter of at least $3 / 8$ inch, a live terminal bud, and a well developed root system. Black walnut and yellow-poplar can be planted with a bar or mattock, taking care to avoid doubling or twisting the roots. Control herbaceous plants until the tree seedlings have outgrown the weeds. Inject woody plants with a registered herbicide. Planting on a spacing of 10 by 10 feet permits cross cultivation where feasible. Yellow-poplar will prune itself at such a spacing unless many of the seedlings die. Start pruning the black walnut when it is about 5 years old.

The three most important points to remember when planting hardwoods are: (1) Selecting the planting site. Be sure that the species is suited to the site. (2) Plant only large, healthy seedlings, with an adequate root/top ratio. (3) Be prepared to control competing plants until your tree seedlings are well established and free to grow.

\section{INTERMEDIATE CULTURAL TREATMENTS FOR PINE}

\section{PRECOMMERCIAL THINNING}

Many acres suffer from having too many young trees. These problem areas include sites that were direct seeded with too many seeds and those naturally reseeded either after a wildfire or after intensive site preparation. If the sites remain untreated, the time it will take the trees to become merchantable may be doubled. If the stand contains more than 1,500 seedlings 
of the preferred species, you may wish to thin it precommercially at ages 2 to 5 . Precommercial thinning is needed particularly in dense stands of shortleaf and slash pine, because these species do not become dominant as quickly as loblolly and longleaf pine. Thinning is also needed on poor sites to promote early dominance by the desired species.

Hand thinning may be the only practical method on small tracts, but is usually too expensive or the labor is not available. When hand thinning, leave single trees 8 to 10 feet apart. Otherwise, use a bush-hog or brush cutter on saplings less than 5 feet tall. A heavy-duty chopper may be used for trees 5 feet and taller, but no more than 3 inches in diameter, cutting 8- to 10 -foot lanes through the young stand. Keep the leave strips as narrow as possible. When successfully treated, the stand will appear to have been decimated.

\section{THINNING}

Once a planted or natural stand reaches pulpwood size, it is time to consider thinning to: (1) increase the rate of return on the forest investment by developing large trees that bring high stumpage prices, (2) obtain early returns to liquidate the establishment or cultural costs promptly, (3) provide periodic income, (4) salvage trees that will soon die, (5) concentrate growth on the best trees, (6) provide better access for fire equipment, and (7) enhance wildlife habitat.

Factors governing selective thinning to obtain these advantages include size, quality, rate of growth, defect, spacing and species (in mixed stands). During the first thinning wait until the average tree to be cut is at least 6 inches in diameter, and the smallest trees to be cut into pulpwood have at least $10^{1 / 2}$ feet to a 4-inch top outside bark. If you do your own marking and your own harvesting, selective thinning has no peer. For many, however, row thinning in plantations or "road" thinning in natural stands is most practical because it makes mechanical harvesting possible and facilitates trucking, particularly for the first thinning.

Where the trees are not in rows, leave 15-foot strips of trees between cut swaths 10 to 12 feet wide. Remove selected trees 
from the leave strips. For plantations with 700 to 1,000 trees per acre, when fusiform rust is not a major problem (less than 20 percent of the stand infected), remove every third row. Limited selective thinning can be done in residual rows to upgrade the stand. Removal of every fourth row has several advantages: (1) selective thinning of the two remaining outside rows can be quite flexible; (2) diseased trees can be removed without diminishing the stand; and (3) row thinning can be used on the middle row the next time around if necessary.

For anyone familiar with basal area, a good rule of thumb is to cut back to 85 square feet on the better sites when thinning at 5-year intervals or when frequent thinnings are not possible; and to 70 square feet when the objective is to grow sawtimber on rotations of less than 40 years. A guide for thinning pulpwood-size stands is given in table 2 .

\section{PINE RELEASE CUTTING}

Release, by definition, is the freeing of a tree from immediate competition by cutting or otherwise eliminating less desirable trees (generally, low value hardwoods) that overtop or closely surround the desired trees. The need will vary by species, site and past treatment. The problem is generally not as severe in the Coastal Plain as in the Piedmont and mountains. Twenty or more years ago, many oak-pine and oak-hickory stands had an understory of young pine. Today, because of infrequent fires, pine seedbed conditions are poorer and competition from seedling and sapling hardwoods is greater. Periodically following a good seed crop the floor of oak-pine and some oak-hickory stands will be covered with pine seedlings.

Cutting or deadening overtopping, low value hardwoods will greatiy increase the survival and growth of young pine seedlings as a result of increased light and greater availability of soil moisture. Although release during the seedlings' first year is preferable, release postponed as long as 8 years has been effective with lobloliy pine. Less than complete treatment of hardwoods generally results in the need for a repeat release about 3 years after the initial treatment because of resuppression by 
Table 2. - Guidelines for management of pulpwood-size stands ${ }^{\prime}$

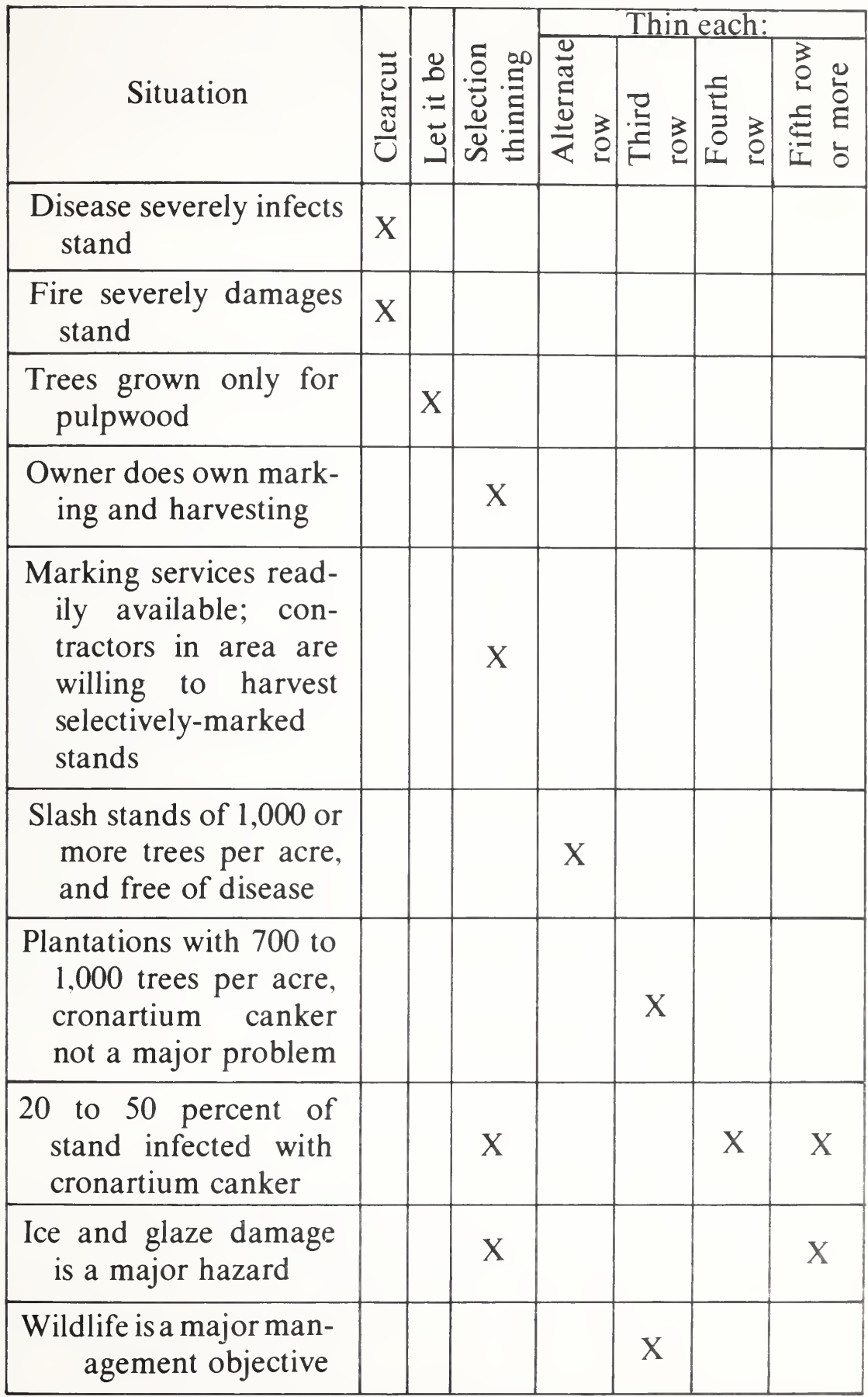

'Intended only as a quick checklist. Ir many cases, more than one alternative is open to your choice. Decisions must be made on an individual basis. 
hardwood sprouts, or by the spreading crowns of hardwoods not treated initially.

Release cutting is often the cheapest way to obtain a fully stocked pine stand. The treatment is effective with all four of the major southern pine species. Release cutting is also effective where stands are being managed for quality hardwoods, but the techniques are more selective and complex.

\section{IMPROVEMENT CUTTING}

In the cutover forests of the South about one-third of the growing space in pine-hardwood and hardwood stands is occupied by cull or low value trees - trees that, because of undesirable form, quality, condition, growth rate or species, should be removed to stimulate the growth of better trees. The feasibility of such a cut is determined by the amount and quality of the material to be removed, local market conditions, logging conditions, and the stocking of desirable trees that will be left following the cut.

An improvement cut is practical if, following the cut and associated deadening operation, at least 40 to 50 percent of the area will be stocked with desirable trees. Local market and logging situations will determine how many trees will need to be cut to interest a buyer.

Examples of trees that should be removed include:

1. Badly suppressed trees, which are certain to go out of the stand within the next 5 years through natural mortality.

2. Trees having crooked trunks that will never produce sawtimber.

3. Trees that show unmistakable evidence of heart rot or other tree-destroying fungi.

4. Trees that contain fire scars or other injuries so severe that they are susceptible to wind damage. 
Improvement cuts will pay off in increased growth of higher quality wood and reproduction of desirable species. Such cuts also make use of a large volume of timber that would otherwise die of natural causes or decrease in quality before the next cut.

\section{PRUNING}

Pruning is profitable only when premium prices are offered for higher quality logs. Early pruning will restrict the knotty core. No more than 75 crop trees per acre should be pruned. Pruning should leave about 50 percent of the trunk in live crown; more severe pruning may interfere with rapid growth of the crop trees. Limbs should be pruned when they are small, without leaving a stub, to ensure rapid overgrowth of the knot. Wounds heal faster if the limbs are pruned close enough to the trunk of the tree to cut the living cambium (the layers of tissue closest to the bark) at the branch node. Confine pruning to trees on the good and better sites. Thin repeatedly and heavily to release the pruned trees from competition, to obtain highest profits from pruning. Before investing in pruning, find out if an appropriate increase in stumpage prices can be expected.

\section{HARDWOOD CONTROL TECHNIQUES}

Site preparation for a new crop of trees, improvement cutting, and release cutting require some knowledge of how to control or eliminate unwanted hardwoods. In the early days, hardwoods were cut, girdled or frilled with an axe. If the trunks are 10 inches in diameter or less, sprouting is generally profuse. This unwanted result has led to the use of chemicals.

You will probably find that tree injectors are the easiest tool to use. Tree injectors are metered to discharge selected amounts of undiluted herbicides into each incision in a tree. These incisions are generally made within several inches of the groundline when using 2, 4-D, although they have been effective at waist height when made by a hatchet that dispenses other herbicides. 
Inject easy-to-kill hardwoods (See table 3) during the growing season with a 2-milliliter dose of undiluted 2, 4-D amine in incisions, leaving a 2 -inch gap between incisions. With resistant hardwoods, leave no gap between the incisions around the base of the tree. During the dormant season or when most of the species to be treated are resistant to 2, 4-D, use Tordon 101R (picloram $+2,4-D$ ) in the same manner. A prescribed burn before treatment aids access and increases kill.

Spraying with a tractor-mounted mist blower is an approved practice in some States. This approach is the most practical control procedure when the overstory is too dense to treat from the air, the understory is too large for prescribed fire, and there are too many small trees per acre for tree injection. Some advantages of mist blowing over aerial spraying and high-volume ground spraying are: (a) efficient treatment of small or irregularly shaped areas; (b) small hazard of drift: (c) good coverage of foliage of understory plants; and (d) a volume of herbicide and carrier for ground spraying which is as low as that required by aerial spraying. Backpack mist blowers are particularly suited to small forest owners, and are effective on small or remote tracts where aerial and heavy ground equipment are not feasible.

Several herbicides are being evaluated for use in releasing pine by mist blowing and aerial- or ground-applied granular material. Use of 2, 4, 5-T is presently suspended by the Environmental Protection Agency. Some ground-applied herbicides are also promising. They are effective on sandy sites, but not on heavy, clay soils or wet sites. Contact your local forester to determine their availability.

Hexazinone in pellets is registered for use in some States, for pine release. For site preparation, several chemicals are available for mist blowing or aerial application. Those registered for such use are: 2, 4-D, Tordon 101, dichlorprop, dicamba, triclopyr, fosamine ammonium, and glyphosate. Follow direction on labels carefully. 
Table 3. - Relative susceptibility of hardwoods and redcedar to herbicides.'

Injection with 2, 4-D amine

$\begin{array}{lll}\text { Susceptible } & \text { Intermediate } & \text { Resistant } \\ \text { Cherry, black } & \text { Beech } & \text { Ash, green } \\ \text { Cherry, fire } & \text { Blackgum } & \text { Ash, white } \\ \text { Cucumbertree } & \text { Elm, winged } & \text { Dogwood } \\ \text { Elm, American } & \text { Hawthorn } & \text { Hickory } \\ \text { Oak, black } & \text { Hornbeam, American } & \text { Holly } \\ \text { Oak, blackjack } & \text { Huckleberry } & \text { Locust, water } \\ \text { Oak, overcup } & \text { Locust, black } & \text { Maple, red } \\ \text { Oak, post } & \text { Oak, water } & \text { Oak, chestnut } \\ \text { Oak, scarlet } & \text { Pecan, bitter } & \text { Privet, swamp } \\ \text { Oak, southern red } & \text { Persimmon, eastern } & \text { Redcedar, eastern } \\ \text { Oak, white } & \text { Sumac } & \text { Sourwood } \\ \text { Oak, willow } & \text { Sweetbay } & \\ \text { Sassafras } & \text { Sweetgum } & \\ \text { Willow } & & \\ \text { Witchhazel } & & \\ \text { Yellow-poplar } & & \\ & & \end{array}$

'General guide only. The susceptibility of species varies with conditions at the time of treatment. 
Table 3. - continued ${ }^{1}$

Injection with Picloram + 2, 4-D (Tordon 101)

\begin{tabular}{lll}
\hline Susceptible & Intermediate & Resistant \\
\hline $\begin{array}{l}\text { Cherry, black } \\
\text { Hornbeam, American }\end{array}$ & $\begin{array}{l}\text { Beech } \\
\text { Blackgum }\end{array}$ & $\begin{array}{l}\text { Ash } \\
\text { Dogwood, } \\
\text { rough leaf }\end{array}$ \\
$\begin{array}{l}\text { Macust, black } \\
\text { when sap is flowing) }\end{array}$ & $\begin{array}{l}\text { Hickory } \\
\text { Oak, black }\end{array}$ & \\
Oak, blackjack & Redcedar, eastern & \\
Oak, chestnut & Sourwood & \\
Oak, post & Sweetbay & \\
Oak, scarlet & Sweetgum \\
Oak, southern red & \\
Oak, white & \\
\hline
\end{tabular}

General guide only. The susceptibility of species varies with conditions at the time of treatment.

Spray after the trees are in full leaf. Remember that too much oil in the solution injures young pine. Do not spray during or immediately after periods of drought; herbicide effectiveness is better when there is plenty of soil moisture. Spray when the wind is less than 5 miles per hour. The average droplet size should be about 90 microns. When using mistblowers, spray swaths should be about 33 feet apart. Stop spraying when the leaves begin to harden off, generally in late July or early August. The susceptibility of some species is given in table 3. 
Skillful use of prescribed fire periodically throughout the life of a stand can economically control smaller unwanted woody plants. A prescribed burn just before harvest makes both harvesting and later release work easier and more efficient.

Honeysuckle and kudzu vines reduce growth and badly deform trees in some places. To get rid of them, burn or disk honeysuckle and kudzu during the dormant season. Honeysuckle has persistent leaves and may be more difficult to burn. Following the burn and just before crown sprouting, broadcast 60 pounds per acre of Tordon $10-\mathrm{K}$ pellets. Spot treat any surviving crowns with 1 teaspoonful of pellets 60 to 90 days later. Pines may be planted on the treated area during the dormant season. Spot treat any surviving crowns during the spring of the year.

\section{HARVEST CUTTING}

The four methods of harvest cutting include: clear cutting, seed tree cutting, diameter limit cutting, and selection cutting. Harvest cutting should take place only when the stand is mature, badly highgraded, or so understocked or diseased that it offers no potential for continued management. Economic maturity for pine will vary depending on local markets, establishment costs, growth rates, landowner objectives, etc. Highest stumpage prices for pine in many areas are attained when the trees are 16 to 18 inches in diameter at breast height (d.b.h.).

Clear cutting removes all of the merchantable timber in one operation. This practice is highly desirable when used to regenerate overmature or badly understocked stands, to convert less desirable stands of off-site hardwoods (oak-hickory) to a highly desirable stand (pine), or whenever you are ready to regenerate intolerant species. Clearcutting has been given a bad name because some owners fail to provide for immediate regeneration of a new stand, and because of the temporary lack of beauty of the area. To ensure the practicality of clearcutting, 
immediate planting, or reseeding in the case of a pine stand, is required. Chopping may be used to liquidate unwanted saplings and advance reproduction of hardwood stands.

In seed tree cutting, the stand is clear cut, leaving a sufficient number of trees of the desirable species to cast seed over the entire area. The number of seed trees to be left depends upon their size, species, seed-bearing characteristics, and site conditions. More details are given in the Regeneration section.

The term shelterwood is often used. In the South, this term has become synonymous with a heavy seed tree cut in which 20 or more large trees are left. These trees may be removed in more than one cut. Among the southern pines only longleaf pine requires the shelterwood method because of its poor seeding habits.

Diameter-limit cutting was widely used in the past. No marking was required. Instead, all trees of a certain stump diameter and larger were specified for removal. This system is not recommended because it leads to highgrading the stand removing the best and leaving the poorest trees.

The three previously mentioned systems produce evenaged stands. Many landowners have uneven-aged stands better, all-sized stands - that are adapted to selection cutting. This method of cutting entails the removal of the mature timber either as single, scattered trees or in small groups at fairly short intervals. Successful selection cutting depends upon the ability of tree reproduction to become established, and to survive in the openings left in the stand by the removal of the economically mature timber. Use single tree selection to thin the younger portions of the stand and to shape the stand structure. Use group selection - clear cutting patches of mature areas - to open up regeneration areas. The beauty of this system is that you can harvest some trees periodically and yet continue to have a well stocked forest at all times.

All trees to be cut should be marked with paint at breast height and at the ground line. Consider cutting all sizes of trees from 5 inches d.b.h. to the maximum size to be grown. Much of the marking will be done to thin the stand and release the better 
trees for further growth. The objective in marking should be to grow quality trees for sawlogs, veneer or plywood, and poles. In well-stocked stands on a good site, 25 to 30 percent of the volume can be removed periodically without depleting the growing stock.

\section{INTERMEDIATE CULTURAL TREATMENTS FOR HARDWOODS}

Hardwoods predominate on more than one half of the forests in the South. Where there is a pine seed source, it is generally more profitable to manage for pine. If the site is dry, convert it to pine by planting loblolly in the coastal areas, shortleaf in the cooler interior, and white pine in the cold, mountainous areas. Manage most of the moist sites for hardwoods. Such areas include the small stream and river bottoms, coves, and north- and east-facing slopes.

Intermediate cultural treatments for hardwoods include precommercial thinning, commercial thinning, release cutting, and improvement cutting. Present markets for small hardwoods are rarely good. The goal in hardwood management should be to produce high quality wood.

All of the intermediate cultural treatments should be aimed at stimulating the growth and maintaining the quality of the crop trees - the best trees of the preferred species that will make up the final harvest cut. Favored species include the oaks, yellow-poplar, walnut, ash, sycamore, sweetgum, and several other, less prominent species for certain situations. These crop trees should occupy a dominant or co-dominant position in the stand, be straight and tall with relatively small branches, and show signs of self pruning on the butt 16 feet. To produce quality trees, fire must be kept out of the stand; any logging must avoid scarring of the crop trees. Thinning should not open up the stand so much that epicormic (sprout) branching is induced on the lower trunk. Precommercial thinning can be done to improve the growth and development of crop trees, but this cutting should be delayed until the crop trees can be identified as having 
dominant or co-dominant crowns within the stand. The stand will usually be 15 to 20 years old before this condition prevails.

In even-aged stands a commercial thinning for pulpwood (when markets are available) should be made when the crop trees average 8- to 10 -inches in diameter. Remove mainly 6- to 8 -inch trees that compete with the crop trees. Where pulpwood markets are lacking, cut the less desirable trees for fuelwood. Repeat thinnings may be made at 10 -year intervals, but no cutting at all is usually better than the premature harvest of a large number of desirable 8-, 10-, 12-, and 14-inch trees, which would usually be replaced by less desirable trees.

Previous cutting may have left a stand with a wide range of diameters and with many low quality trees in it. In such instances; a commercial improvement cut may be made to remove over-mature, damaged, and dying trees of marketable size and quality if enough vigorous, desirable trees are left to adequately stock the stand. If necessary, a few high quality trees may be cut to attract buyers. Improvement cuts ultimately will mold a hardwood stand into even-aged groups of trees. Some species, chiefly cottonwood, willow, sweetgum, baldcypress, yellowpoplar, and the tupelos, usually occur in even-aged, almost pure stands.

Make the final harvest cut when the average crop tree is about 20 inches d.b.h. If there is no pressure to cut, you may wish to grow them to be 22- or 24-inches d.b.h. Every additional inch in such trees is extremely valuable. On poorer sites, your most profitable option may be to harvest the crop trees when they are only 16 inches d.b.h.

Selection of the type of harvest cut should be influenced by the regeneration requirements of the species in favor. Consider leaving some areas of large hardwoods for game food and shelter.

You would be wise to get professional advice on hardwood cultural treatments. 


\section{FOREST PROTECTION}

FIRE

More than 70,000 wildfires and about 1 million acres burn each year in the South. Both nationally and in the South, incendiarism is the number one cause. Debris-burning fires that escape are another major cause. These fires account for 30 to 35 percent of the wildfires in the South. They are one of the more preventable fire causes. In most cases, debris-burning fires are the result of carelessness. Use caution when burning debris! Contact your local forestry agency before burning.

Small surface fires kill seedlings and small trees, especially if the soil and litter are dry. Crown fires may wipe out a productive stand of large trees converting the area to a brush stand of inferior species. Even though a wildfire may not kill a tree, it may leave a fire scar where disease can enter if the intensity is hot enough to penetrate the bark, especially on hardwoods. Fire-weakened trees may also be attacked by insects or felled by the wind years after the fire.

Wildfire can impair the ability of watersheds to absorb rainfall and hold back runoff, fosters erosion, lessens the storage capability of the soil, and can reduce the water quality in adjacent streams and lakes because of sedimentation. Large, fastspreading fires can kill animals trapped in the fire and destroy the nesting areas of birds.

Wildfires consume all of the litter, and repeated annual burns will damage the more palatable forage such as yellow indiangrass and the big and little bluestems, favoring less desirable species such as threeawns and lovegrasses. Uncontrolled wildfires reduce the quality of forage production. Wildfire can drastically reduce visibility and create locally hazardous conditions for aircraft and highway traffic. Forest fires contribute an estimated 8 percent of the total burden of air pollution.

Fire is a poor master but a good servant. In pine management, fire is a versatile and economical tool. However, fire is seldom prescribed for use in hardwoods. Prescribed burning done by trained specialists consumes less material, resulting in 
the release of less pollutant material than that created by a wildfire. Prescribed burning also reduces the potential damage from wildfire by controlling fuel buildup (dead branches, leaves, and other debris on the ground). Prescribed fire is useful in site preparation, and can control competing plants without disturbing the soil and humus layers. Fire controls brownspot and increases visibility for marking, logging, and hunting. Prescribed burning is an important management tool in improving wildlife habitat. When prescribed fire is used properly, it can improve the availability, quality, and palatability of forage, and controls undesirable species.

About $2 \frac{1}{2}$ to 3 million acres are prescribed burned annually in the South on all ownerships. Prescribed burning requires skill and good judgment. Among the techniques that must be mastered to use fire as a tool are: selecting the best method of burning, timing the burn, selecting proper weather conditions, and managing the fire for smoke control to prevent off-site problems. Ask for assistance from experienced sources such as your State forestry agency

Construct permanent firebreaks to divide pine stands into blocks no larger than 40 acres, and to separate areas to be managed for hardwoods from the pine type. Access roads may serve as firebreaks. Where young pine has been planted or seeded along a public road, you may need to maintain a plowed or disked fireline between the road and the pines until the stand can be fireproofed by a prescribed burn. Plowed lines should be carefully located and constructed to avoid erosion. Where incendiarism is a problem, a cooperative effort with one's neighbors can frequently eliminate the source.

\section{INSECT AND DISEASE DAMAGE}

Although many kinds of insects attack pines, only four groups cause major problems: reproduction weevils (figure 11), tip moths, sawflies, and bark beetles (southern pine beetle, pine engraver beetles, and the black turpentine beetle; see figure 12). 


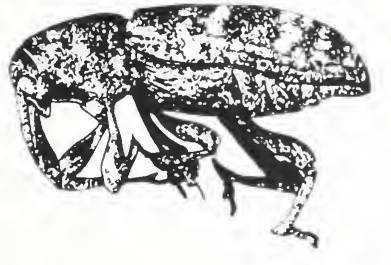

Figure 11. - Reproduction weevil.
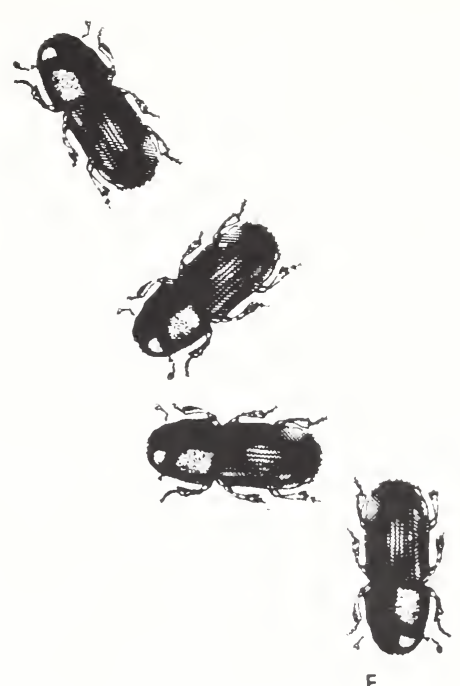

Figure 12. - Bark beetles.

The odor of fresh pine resin attracts reproduction weevils to areas where pine is being cut. The weevils deposit their eggs in the large roots of fresh pine stumps, where the larvae develop in the inner bark of the root. On emerging, the new adults feed on the tender bark of pine twigs or seedlings, frequently girdling them. Damage can be reduced by a 9-month delay in replanting pines on a cutover area, or by use of pesticides. An alternative is to dip seedling roots in a clay slurry containing carbofuran before outplanting, or spray the seedlings with Dursban $4 \mathrm{E}$ immediately after planting. Check before planting to see if these weevils are a problem in your area.

Tip moths prefer loblolly, shortleaf. Virginia pine, and occasionally attack slash pine. but do not harm longleaf or eastern white pine. Their attacks rarely have much effect on growth, and usually cease to be a problem after trees grow to about 10 to 15 feet, although sometimes tip moths are found on trees as high as 30 feet. Growth reduction is most serious on poor sites. A partial overstory reduces the incidence of attack. In some areas, you can reduce risks of attack by tip moths if you select a resistant species when planting trees. 
Generally, the worst damage by sawflies is caused by those with multiple generations, which feed in the summer and fall on both old and new needles. Attacked trees may suffer a loss in diameter growth, but usually recover within a year or two. Severe infestations in young plantations will stunt or malform trees, and repeated stripping sometimes kills the trees. Usually, sawfly infestations appear suddenly, continue for one or two seasons and abruptly disappear. Shortlived outbreaks seldom warrant chemical control. If defoliation occurs repeatedly, chemical control may be desirable using diazinon, dimethoate, malathion, acephate, or carbaryl.

The southern pine bark beetles may multiply rapidly and cause widespread timber losses if conditions are favorable for their development. The most common factor associated with beetle outbreaks is poor tree vigor caused by drought, fire, lightning, flooding or careless logging. Thus, the best way to avoid timber losses from bark beetles is to maintain vigorous growth of the stand through stocking control and avoid damage to trees while logging. Control methods include rapid salvage and utilization, piling and burning infested material, or employing cut-and-spray practices using lindane, Dursban 4E, or Sumithion $8 \mathrm{E}$.

Economically, the trunk borers are the most important destructive group of insects in hardwoods. Larvae of the carpenter worm and longhorn beetle attack the trees throughout their growth, and construct large galleries in the wood. Bark injuries at entrance holes become ingrown bark pockets in wood. Microorganisms stain and decay the wood along and adjacent to the galleries. This damage may be greatly expanded by carpenter ants that occupy vacated borer tunnels and hollow out larger cavities. Many smaller species of beetles add to the damage. Remove weak, cull trees that harbor both insects and disease to reduce the level of attack in nearby vigorous trees.

Defoliation by insects restricts tree growth and loss of seed occurs from destruction of tree flowers. For example, forest tent caterpillars defoliated coastal gum forests, limiting growth to about one-fourth the potential for the year, and prevented seed production. Ultra-low-volume spraying of gum forests and 
cottonwood plantations with selected insecticides has demonstrated effective control of insects without damage to associated wildlife.

Among the most effective defenses against disease are matching species and management practices to site, to maintain healthy, vigorous stands. For example, damage from root rot (figure 13) caused by the fungus Heterobasidium annosum, is related to site. Soils with 12 inches or more of sand in the top horizon are considered high-hazard sites as are old-field sites. Avoid heavy losses on high-hazard sites by planting more resistant species such as longleaf pine rather than the more susceptible loblolly or slash pines. On high-hazard sites, close spacing favors rapid spread of the disease after the first thinning. Delay this thinning as long as possible and make it in the summer, when few fungus spores are present. In the summer, stump temperatures during the day are usually hot enough to prevent spore germination. Apply powdered borax to cut surfaces of stumps immediately after felling on high-hazard sites during cooler season. Use Phlebia gigantia to increase stump decomposition and reduce annosum incidence.

Fusiform rust (figure 14) is a major disease of loblolly and slash pine, but longleaf and shortleaf pine are immune. Close spacing induces early natural pruning, thus preventing branch

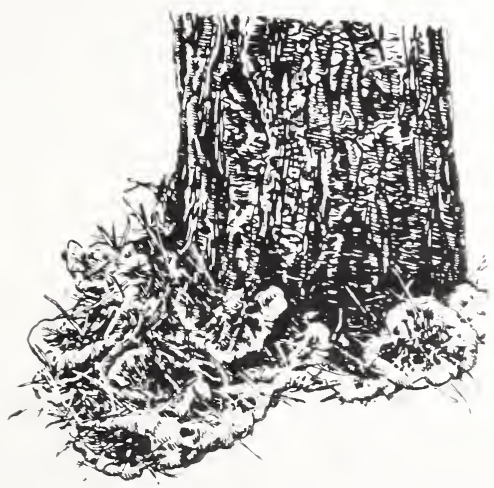

Figure 13. - Root rot.

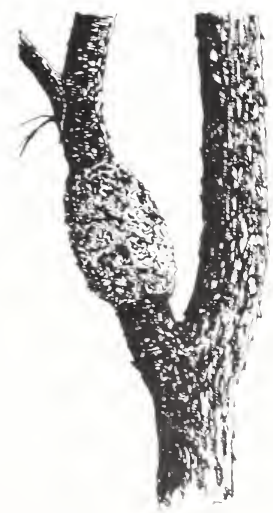

Figure 14. - Fusiform rust. 
galls from reaching the trunk. (Avoid close spacing on annosusprone sites.) Remove infested trees in thinning operations to salvage trees that are starting to die. You may not need to cut all diseased trees. Allow trees heavily infested with fusiform rust to grow for up to 8 more years if less than 50 percent of the trunk circumference is killed (cankered). Disease-resistant strains of pine are being developed.

Littleleaf disease of pine, particularly of shortleaf, is caused by a complex of factors involving the soil fungus Phytophthora cinnamoni, and other adverse factors such as poor aeration, low fertility, and periodic moisture stress. Severe littleleaf sites have thin topsoil (the result of past sheet erosion) underlain by heavy, plastic, poorly drained subsoil. Littleleaf does not spread from tree to tree, but develops where site conditions favor its growth. Select loblolly and other more resistant pines instead of shortleaf pine on littleleaf-prone sites.

Longleaf pine, which is quite resistant to fusiform rust and southern pine beetle attack, is highly susceptible to brown spot needle blight. Strains of longleaf that are highly resistant to brown spot have been identified and are being grown in seed orchards. Until resistant seedlings are available, judicious use of fire in naturally seeded longleaf pine stands will help to control brown spot and to stimulate early height growth.

Fire prevention is important in reducing losses to disease in hardwoods. Trunk rot and canker fungi can destroy much of the valuable butt log following fire injuries. Other diseases enter through broken tops and branch stubs. Careful logging will reduce the number of wounds through which fungi enter standing trees. 


\section{MANAGING FOR MULTIPLE USE}

\section{WILDLIFE HABITAT IMPROVEMENT}

Increasing the production of wildlife on forest land depends on increasing the availability of food and cover. Where timber markets exist, you can improve the habitats of some species by good management practices. Many wildlife species thrive along the edges of openings in the forest. They need a mixture of forest tree species and conditions. Thinnings should be early and heavy to favor mast-producing trees and to open up the understory. Leave den trees for squirrels. Pine stands should be prescribed burned every 2 years for quail, and every 3 to 5 years for deer and turkey.

\section{Squirrels}

Hardwoods are a must for gray squirrels. They require partial hardwood stands of trees old enough ( 25 years) to produce mast and provide dens (40 years). The squirrels' home range is 2 to 8 acres. Reproduction is $2 \frac{1}{2}$ times more successful in tree cavities than nests. Den entrance holes are usually $2 \frac{1}{2}$ to 3 inches in diameter; den cavities 14 inches deep. They should be waterproof and 15 feet or more above ground level. A squirrel needs about $1 \frac{1 / 2}{2}$ pounds of hard mast per week from September through March. Preferred foods are hickory nuts, beechnuts, white oak group and black (or red) oak group acorns, in that order. Supportive foods are berries, soft mast, buds, seeds, and fungi. Red maple is a particularly important source of food in early spring and mulberry in May and June. See table 4.

\section{Quail}

The best habitats for quail include interspersed open forests, brush, grass and cultivated fields, but the birds survive in many forest types. Choice nesting cover is 1-year-old-grass. They also nest at the edges of forest clearings. Each nesting pair should have access to clearings $1 / 5$ acre or larger. Normal range is 40 


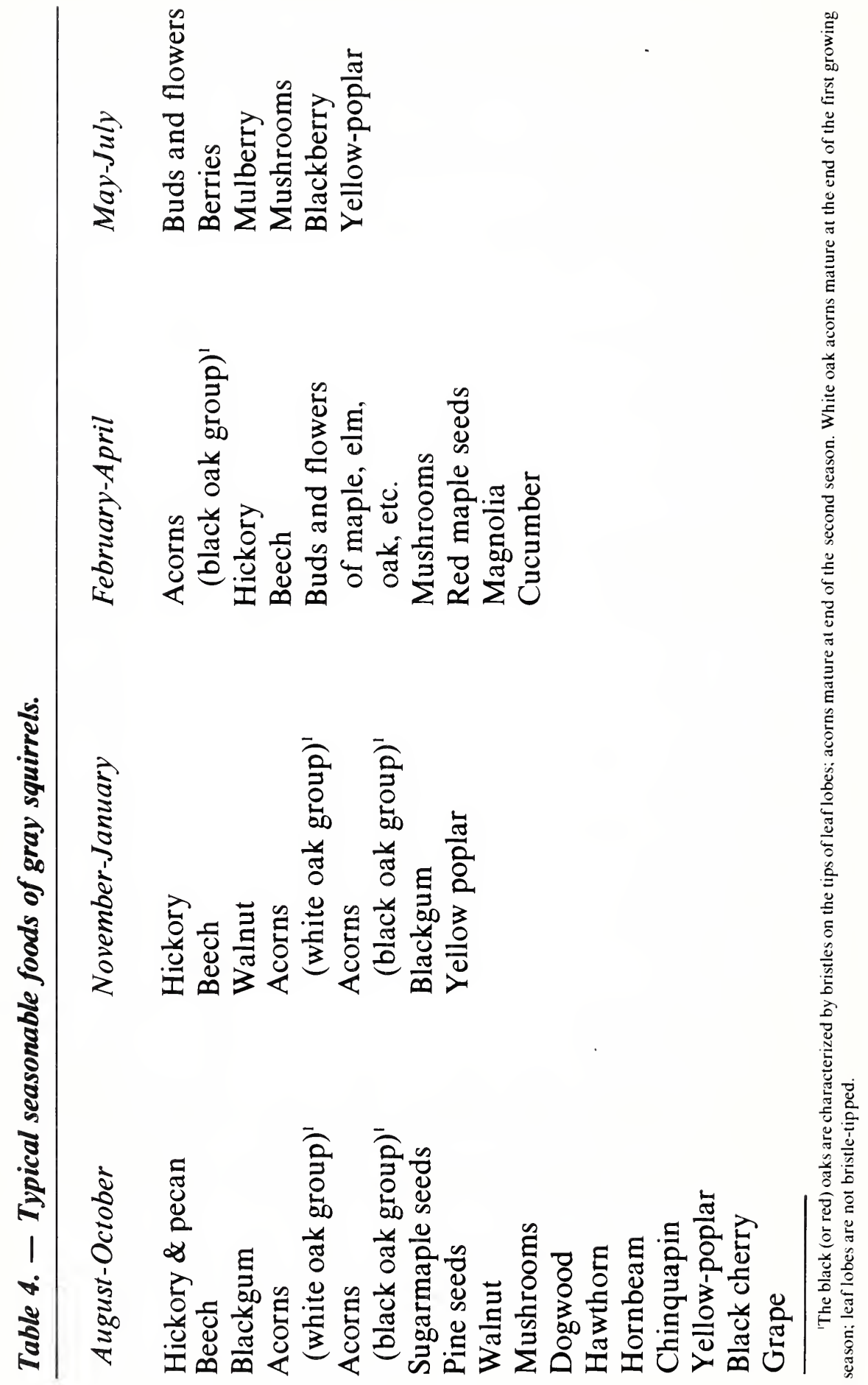


acres. Quails nest from April to September. Seeds make up 85 percent of the quail diet. Legume, grass, and weed seeds are the most important foods, in that order. See table 5.

\section{Deer}

Deer live in most forest and non-forest conditions and types. Their home range seldom exceeds 300 acres where food, cover and water are interspersed. Prescribed burning and fertilization attract deer because of the improved nutrition and palatability of food plants. The early stages of timber rotation and intermediate cuts produce abundant deer browse and fruits. During the fall and winter, deer prefer hard mast (acorns, pecans, beechnuts) and evergreen forage. Rapid-growing green browse and herbage are principal spring and summer foods. Deer require about 6 to 8 pounds in green weight of food daily for each 100 pounds of animal weight. See table 6 .

\section{Table 5. - Important quail foods of the Piedmont and Coastal Plains forests, together with plant part utilized.}

Herbaceous Plants

Ragweed

Beggarticks

Partridge pea

Goatweed

Chufa, nutgrass

Tick trefoil (beggarweed)Seed

Wild millet

Lespedeza

Grasses

Pokeweed

Smartweed

Vetch

Panicum

Milk peas

Butterfly peas
Trees, Shrubs, and Vines

Seed

Seed Hackberry

Seed Flowering dogwood

Seed Persimmon

Tubers Bayberry

Blackgum

Seed Pines, longleaf,

Seed loblolly (preferred)

Seed Cherry

Berry Oaks

Seed Sumacs

Seed Blackberry

Seed Grapes

Seed Magnolia, bay

Seed Sweetgum
Seed

Seed

Seed

Seed

Seed

Seed

Seed

Seed

Seed

Seed

Berry

Berry

Seed

Seed 
Table 6. - Major sources of food for deer, in order of preference, in each of three areas.

Mountains

Greenbriar

Azalea

Blueberry

Chestnut

Dogwood

Blackgum

Oak

Sourwood

Mountain laurel

Huckleberry

Strawberry-bush

Buffalo nut

Japanese honeysuckle

Blackberry

Sumac

Hydrangea

Aralia

Grape

Rhododendron
Piedmont
Coastal Plain

Japanese honeysuckle Black titi

Greenbriar

Yellow-poplar

Tall gallberry

Azalea

Greenbriar

Viburnums

Sourwood

Blackgum

Dogwood

Honeysuckle

Blackberry

Yellow jessamine

Myrtle holly

Soft maple

Blueberry

Cherry

Persimmon

Blackberry

Strawberry-bush

Wild rose

Deer's tongue

Mushrooms

Sumac

Prickly pear

Yaupon

Sassafras

Viburnums

Strawberry-bush

\section{Turkeys}

Good turkey habitats contain mature stands of mixed hardwoods, groups of conifers, relatively open understories, and scattered clearings, well distributed over the area. Openings are essential for raising young turkeys, A home range is about 1 square mile. Turkey diets consist mainly of grass and weed seeds in the fall. mast and forage in winter and spring, and forage and insects in the summer. Acorns, dogwood berries, clover and pine seed are the foremost foods. Soybeans, corn, and pasture are the farm crops most often used. See table 7. 
Grass and weed seeds

Paspalums (bullgrasses)

Panicums

Native legumes

Hard mast

Acorns

Beechnuts

Pecans

Forage

Clovers

Grasses

Sedges

Soft mast

Dogwood

Grapes

Cherries
Other tree seeds

Sweetgum

Pine

Insects and snails

Grasshoppers

Millipedes

Insect larvae

Berries

Blackberries and dewberries

Huckleberries

Strawberries

Grain

Oats

Corn

\section{Nongame Birds}

Just as diversity is the spice of life so are diversity of tree species, age of stand, and stand density the key elements in providing woodland habitats favorable to nongame birds. Some birds are found mainly in the forest interior, some in forest edges and areas with scattered trees, and some are found in both of these areas. Some forest management practices decrease the complexity of the forest while others increase it. Practices that can destroy the understory appear to be harmful to some nongame birds. Examples include intensive site preparation, annual burning, removal of dead trees and snags, as well as measures to promote monoculture (such as intensive hardwood control in pine stands.) 
Several strategies can be used to increase nongame bird numbers and species. The following examples of some of these strategies are not intended to be used all together on the same tract:

- Manage for a mixture of pine and hardwood (not necessarily in the same stand but in adjacent stands).

- Maintain some stands of 80 years or more in age to provide suitable cavities for nesting and the production of high energy fruits and mast.

- Make long, narrow clearcuts with undulating edges.

- Foster low thickets of brush and vines, and piles of brush or tree tops for nest sites.

- Plant pine at wide spacings, with subsequent heavy thinning.

- Regenerate forest stands by natural methods.

- Practice uneven-aged management, with group selection.

- Use prescribed burns infrequently.

- Leave snags and hardwoods with cavities.

\section{CATTLE GRAZING}

Some forest conditions provide opportunities for livestock grazing. Southern pine forests, particularly in the very young or old age classes usually contain the best opportunities. Grazing opportunities depend not only on the forest forage conditions, but also on associated pasture, fencing, water and livestock handling facilities. Coordinated management of timber and livestock practices is a must for a successful operation. Shading by hardwoods under pine stands should be controlled to allow maximum sunlight on the forest floor for best forage produc- 
tion. Because forest forage declines in nutrient and energy values in the fall and winter, some feed supplement is needed to maintain livestock production. Options include winter pasture, hay, crop residues, and feeds such as cottonseed cake. Hardwood stands contain little forage for livestock. Young trees must be protected from livestock for several years, or stands will be poorly stocked and trees damaged. Trees desired for timber management should be at least 10 feet tall before livestock use the area, if timber production goals are to be met.

Prescribed fire is a useful tool to improve the availability, desirability and nutrient quality of native forage for livestock in pine stands. Fire will reduce needle and leaf accumulations and competition from hardwood brush. Native grasses of southern pine forests usually tolerate any type of prescribed burn whether back, head, strip or flank. Late-winter burns are best for forage because grass regrowth occurs fairly soon. Begin prescribed burns when pines are 10 to 15 feet tall. The first burn should be a backfire, with steady winds, cool temperatures, and medium fuel moisture. Then burn at 3-year intervals in pine-bluestem types. Burn at 2-year intervals in the wiregrass types. Where possible, rest prescribed burn areas for 4 to 6 weeks before beginning grazing because cattle usually concentrate on fresh burns.

Careful planning and coordination are needed to include forest grazing with timber and wildlife management goals. Adequate forage and supplements must be provided to livestock. The number of animals must be adjusted to forage production levels and to forest conditions to meet livestock and other management goals.

\section{WATERSHED MANAGEMENT IN THE FOREST}

The key to reducing surface runoff from forest lands lies in proper management of the forest floor (including the litter produced by shrubs and weeds). Starting with bare soil, accumulating forest litter effectively stops soil movement and begins to reduce runoff within 3 to 5 years. With time, more 
water will soak into the soil as organic matter blends into the surface soil, thus further reducing runoff. Of course, the forest floor must be protected from excessive disturbances to accomplish these improvements.

Partial cutting at periodic intervals permits timber production and watershed protection to continue in harmony. Clear cutting, too, can be acceptable if not used on steep slopes and on highly erodible soils. Logging truck roads and skid trails are among the leading contributors to watershed deterioration. Skidding, particularly when done perpendicular to the slope, can expose bare and loose soil to the rain and provide channels for rapid surface runoff. Roads and trails compact the soil so that less water soaks in; streams are often choked with dirt and debris from these trails.

Advance planning of the logging operation can prevent much of this erosion by confining the roads to the ridge tops. Roads should be located just to one side of the ridge line to improve drainage. When roads traverse the hillside, they should follow the contour as much as possible; try to avoid excessive cut and fills. Road grades of 3 to 5 percent are desirable; however, sustained grades of 6 to 8 percent are acceptable in many situations. An occasional short pitch of up to 15 percent can be tolerated if proper road drainage is built into the road, to avoid unacceptable erosion. Use dips to break long grades. Construct water bars as needed and outslope roads beds. See figure 15 and table 8 . Locate the roads far enough from water courses for the storm water to spread out and soak into the forest floor. Keep trucks, tractors, skidders, and logs away from drainage channels. When logging is over, smooth out ruts and holes to prevent channeling runoff, install water bars as needed, and seed the abandoned roads with fescue, winter rye, or other grasses or legumes.

Skidding should be uphill to a ridgetop landing. Logs will then move in a fan-shaped pattern of skid trails as they go downhill, dispersing any water moving down the trail rather than concentrating it as would occur if the landing were at the bottom of the slope. Along intermittent drainage and stream channels, maintain undisturbed strips of forest floor 25 feet 
Figure 15. - Profile of skid road showing water bars."

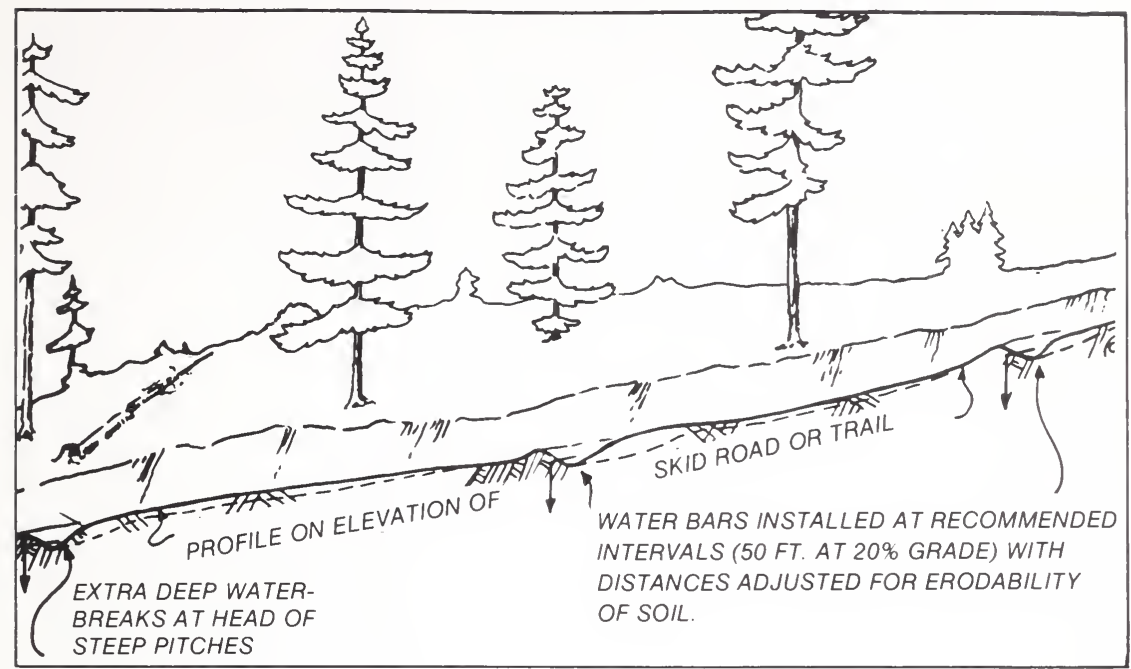

*Reproduced from figure 31, in Permanent Logging Roads for Better Woodlot Management, by Richard F. Haussman and Emerson W. Pruett.

wide, plus an additional 2 feet for each 1 percent increase in slope. These strips will filter out any sediment, preventing it from entering the channel.

Soils and water coming from the public road system are often overlooked by landowners. Maintenance workers tend to scrape out the ditches too frequently and too deeply, destroying the cover holding the soil in place and speeding up the movement of water and soil. Downhill drains from culverts are straightened and deepened, speeding up the runoff, thereby increasing its capacity to erode the soil. A word to the road foreman will often remedy these problems. Where the best watershed protection is desired, road water runoff should be slowed and encouraged to spread out so it will drop its load of sediment. Plant trees along but not in the drainage channel to slow bank cutting. 


\section{Grade of road}

percent

2

5

10

15

20

25

30

40
Distance between water bars

feet

250

135

80

60

45

40

35

30

*With the skid roads protected and "put to sleep," little attention will need to be given to them during the ensuing years. And. when the time comes to remove another crop of timber from the area, the protected logging road will result in lower operating costs and correspondingly higher timber prices to the landowner. (This table is reproduced from table 3 in Permanent Logging Roads for Better Woodlot Management, by Richard F. Haussman and Emerson W. Pruett.)

\section{RECREATIONAL OPPORTUNITIES}

The family forest provides space, shade, clean air, cool nights, probably a stream or a pond, fishing, hunting in season, but most of all an opportunity to get away from the pressures and tensions of daily life. The forest provides a place to pick berries, gather nuts, observe wildflowers and wildlife, study nature and become involved in wholesome outdoor projects such as woodcutting. The natural beauty of a family forest is enhanced to the owner by the care taken to preserve and improve favorite scenic areas. 
Forest management practices such as timber harvests often provide a means to help owners enjoy their forests. Logging roads and skid trails often require little additional effort to maintain for walking trails or wildlife observation paths. Timber harvests can also open vistas so attractive forest or rural settings can be seen. Wildflowers, rare in the dense forests, often flourish in openings prepared for tree planting.

Hiking, horseback riding, and trailbike riding can be done over a network of rough forest roads developed for logging access, or fire breaks. Such roads should be at least 10, but preferably 15 , feet wide, with leadoff ditches and water bars where erosion hazards exist. To be effective as a firebreak, seed the road to grasses or legumes that remain green and relatively nonflammable during the winter forest fire months (October 15 to May 15). Kentucky fescue, a perennial grass, provides good winter cover and can be grown in combination with white clover or winter peas. Rye grass, an annual, will quickly protect the soil. Common bermuda grass is widely used in some areas. These forest roads should be fertilized and limed every 3 or 4 years to maintain a good cover.

Aesthetics will govern how many owners manage their land. Species such as blackgum, dogwood, fringetree, magnolia, mountain laurel, redbud, some red maple, rhododendron, sourwood, sweetgum and yellow-poplar can be reserved along the roads and trails for their flowering habit or colorful foliage. Some owners may even wish to release these species from the competition of other trees.

\section{ECONOMICS}

\section{FINANCIAL CONSIDERATIONS}

Because timber production requires a long term investment, many people may not be able to readily evaluate the financial opportunity from timber or to compare it with other investments. Time and interest rates play an important part in an evaluation of the financial alternatives. 
What interest rate should one use to evaluate forestry investment? The rate should be at least as high as safe investments such as U. S. Treasury bonds and notes. Generally, one should expect more from forestry investments than from other safe investments mentioned above because of the length of time required for a return on the investment. The interest rate should also reflect the risk factors incurred in forestry investments.

Four investment terms are often used in evaluating return on investments for timber production. A brief description of the value and differences among these investment terms follows:

Present Net Worth (PNW) is the difference between the present value of all costs (present and future) and income at a given interest rate. A positive PNW indicates that the investment furnishes a higher return than the selected interest rate. A PNW of zero indicates an investment that equals the selected rate. The selected interest rate usually indicates the investor's minimum objective or alternative investment opportunity.

Annual Equivalent Value (AEV) is the amount of annual income or payment that will just equal the present net worth of an investment during its lifetime. In forestry, the AEV is theoretical because income does not occur on an annual basis. However, AEV figures are useful in comparing forestry investments with investments that have an annual return.

Rate of Return is sometimes called the internal rate of return. The rate of return is the compound interest rate used where the present net worth is zero. In other words, the rate of return is the compound interest rate that equates the present value of all future incomes with the present value of all future costs. All incomes are assumed to be reinvested at the same rate of return.

Cash flow is simply the time and amount of cost and returns. A cash flow diagram is a simple way to show the timing of cost and revenue. The cash flow diagram for a pine plantation costing $\$ 50$ per acre to establish, and yielding returns of $\$ 65$ per acre at age 16 , and a return of $\$ 900$ per acre at year 25 would be: 
Time (year): $\begin{array}{llllllll}0 & 5 & 10 & 15 & 16 & 20 & 25\end{array}$

\begin{tabular}{lllllll}
1 & 1 & 1 & 1 & 1 & 1 & 1 \\
\hline 1 & 1 & 1 & 1 & 1 & 1 & 1
\end{tabular}

Net cash flow: -50

Cash flow is not a true measure of the return on an investment because the effect of time and interest rates on the purchasing power of the dollar are not considered.

Following is a sample of an investment analysis that is typical of the rate of return on a loblolly pine plantation having a site index of 70 , and an annual cost of $\$ 1$ per acre per year. This example assumes a 28 -year rotation:

Rate of return on a loblolly pine plantation

\begin{tabular}{|c|c|c|c|c|c|c|}
\hline \multirow{2}{*}{$\begin{array}{l}\text { Selling } \\
\text { price for } \\
\text { pulpwood }\end{array}$} & \multicolumn{6}{|c|}{ Establishment costs $(\$)$} \\
\hline & 10 & 20 & 30 & 40 & 50 & 60 \\
\hline & \multicolumn{6}{|c|}{. . . . - rate of return (percent) . . . . . } \\
\hline 5 & 12.9 & 10.4 & 8.9 & 7.8 & 6.9 & 6.2 \\
\hline 9 & 15.4 & 12.7 & 11.1 & 9.9 & 9.0 & 8.2 \\
\hline 12 & 17.2 & 14.4 & 12.7 & 11.4 & 10.5 & 9.7 \\
\hline 15 & 18.7 & 15.7 & 13.9 & 12.6 & 11.6 & 10.8 \\
\hline 18 & 19.9 & 16.8 & 14.9 & 13.6 & 12.6 & 11.8 \\
\hline
\end{tabular}

The preceding table shows that if your establishment cost for your plantation is $\$ 50$ per acre, and you receive $\$ 15$ per cord, your rate of return on the investment will be 11.6 percent. 


\section{TAX CONSIDERATIONS}

Family forest managers should be aware of a number of tax benefits. First, net income from timber sales qualify for capital gain tax benefits ( 60 percent of income excluded from tax) if the property has been owned longer than 12 months and certain other qualifications are met. For tax purposes, three ways of selling timber to qualify for capital gains should be understood:

1. Lump-sum. - Use this type of sale if you are not in the timber business, and if you sell your standing timber outright for a fixed sum, agreed upon in advance. You do not have to own a sawmill or other manufacturing concern to be classified "in the timber business." Many times, the deciding factor is how often you make a sale! Check very carefully before you sell your timber on a lump-sum basis because you may lose your capital gains tax benefits. Generally, infrequent (less than 5-year intervals) lump-sum sales of small to moderate size qualify for capital gain tax benefits.

2. Sell as cut. - Use this transaction to sell your timber under a cutting contract, in which your timber is sold at the time it is cut. Under this arrangement, timber is sold on a unit basis (board feet or cord, for example), and payment is made only for those units actually cut. Be careful about selling under these terms! The cutting agreement should be worded correctly to qualify your income for capital gains treatment. See a tax expert. The advantage of sell-as-cut agreements is that you can be classified "in the timber business" and still qualify for capital gains benefits.

3. Use in Own Trade or Business. - Landowners who cut their own standing timber and sell sawlogs, poles or pulpwood as a part of their trade or business can claim capital gains benefits under this category. You may also qualify if you cut your own timber and use it in your trade or business (sawmill owners, for example). In either case, though, you must cut your own timber. 
The amount you received from timber sales is your gross income. Your net income is the amount left after you deduct certain types of costs or expenses from your gross income. You may deduct expenses of sales such as the cost of tree marking, scaling, cruising, consultant fees, and temporary road construction and other improvements that have a useful life of 1 year or less, and are connected with the sale. Costs of $\$ 10,000$ per year or less for work such as site preparation and tree planting qualify under provisions of Public Law 96-451, wherein you receive a 10 percent investment tax credit, and can amortize the entire amount over 8 years.

Operating expenses may be deducted from taxes each year. Examples include the cost of tools of short life, equipment maintenance, salaries (exluding your own time) and professional fees, mortgage interest connected with the timber, and depreciation allowance for equipment.

Tax matters can be very complicated. More details on Federal taxes on timber income may be obtained from a qualified tax consultant. 
Management plans and marketing require that you know the number of board feet that can be sawn from a tree or the volume of pulpwood in a tree. Board-foot tables for the standing trees with diameters at breast height ( $4 \frac{1}{2}$ feet above the ground) and the merchantable height are given in tables 9 through 14. Use tables, 10, 12, and 14 for trees with little taper (Form Class 80) in the butt log. Use tables 9, 11, and 13 for most hardwoods and pines with substantial taper (Form Class 75). These tables give estimates of the gross volume.

Table 9. - Gross volume of tree, form class 75', International $1 / 4$-inch rule ${ }^{2}$

\begin{tabular}{|c|c|c|c|c|c|c|c|c|c|c|c|}
\hline \multirow{2}{*}{$\begin{array}{l}\text { Tree } \\
\text { diam- } \\
\text { eter } \\
\text { (inches) }\end{array}$} & \multicolumn{11}{|c|}{$\begin{array}{c}\text { VOLUME (board feet) BY NUMBER OF } \\
\text { USABLE 16-FOOT LOGS }\end{array}$} \\
\hline & 1 & $11 / 2$ & 2 & $21 / 2$ & 3 & $31 / 2$ & 4 & $41 / 2$ & 5 & $51 / 8$ & 6 \\
\hline $\begin{array}{l}10 \ldots \\
11 \ldots \\
12 \ldots \\
13 \ldots \\
14 \ldots \\
15 \ldots\end{array}$ & $\begin{array}{l}33 \\
42 \\
51 \\
62 \\
72 \\
84\end{array}$ & $\begin{array}{r}43 \\
55 \\
67 \\
82 \\
96 \\
113\end{array}$ & $\begin{array}{r}53 \\
68 \\
83 \\
102 \\
120 \\
142\end{array}$ & $\begin{array}{r}95 \\
117 \\
138 \\
164\end{array}$ & $\begin{array}{l}--- \\
107 \\
132 \\
157 \\
187\end{array}$ & $\begin{array}{c}\cdots \\
203\end{array}$ & \begin{tabular}{r|}
$-\cdots--$ \\
$-\cdots--$ \\
$-\cdots-$ \\
$-\cdots$ \\
181 \\
219
\end{tabular} & 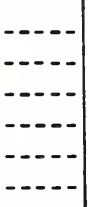 & 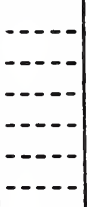 & & \\
\hline $\begin{array}{l}16 \ldots \ldots \\
17 \\
18 \ldots \ldots \ldots \\
18 \ldots \ldots \ldots \\
20 \ldots \ldots \ldots\end{array}$ & $\begin{array}{r}97 \\
111 \\
125 \\
141 \\
157\end{array}$ & $\begin{array}{l}130 \\
150 \\
169 \\
192 \\
214\end{array}$ & $\begin{array}{l}163 \\
188 \\
213 \\
242 \\
271\end{array}$ & $\begin{array}{l}190 \\
220 \\
250 \\
284 \\
318\end{array}$ & $\begin{array}{l}217 \\
252 \\
286 \\
326 \\
365\end{array}$ & $\begin{array}{l}237 \\
275 \\
312 \\
356 \\
399\end{array}$ & $\begin{array}{l}257 \\
298 \\
339 \\
386 \\
433\end{array}$ & 460 & $\begin{array}{r}-\cdots \\
-\cdots \\
\hdashline-\cdots \\
\hdashline 48 \overline{8}\end{array}$ & & \\
\hline $\begin{array}{l}21 \ldots \ldots \\
22 \\
23 \\
24 \\
25\end{array}$ & $\begin{array}{l}175 \\
193 \\
212 \\
232 \\
254\end{array}$ & $\begin{array}{l}239 \\
264 \\
291 \\
318 \\
349\end{array}$ & $\begin{array}{l}303 \\
335 \\
370 \\
405 \\
444\end{array}$ & $\begin{array}{l}356 \\
394 \\
437 \\
479 \\
525\end{array}$ & $\begin{array}{l}410 \\
454 \\
504 \\
553 \\
606\end{array}$ & $\begin{array}{l}449 \\
499 \\
553 \\
606 \\
666\end{array}$ & $\begin{array}{l}488 \\
544 \\
602 \\
659 \\
727\end{array}$ & $\begin{array}{l}521 \\
582 \\
647 \\
712 \\
786\end{array}$ & $\begin{array}{l}554 \\
620 \\
692 \\
764 \\
844\end{array}$ & & \\
\hline $\begin{array}{l}26 \ldots \\
27 \ldots \ldots \\
28 \ldots \\
29 \ldots \\
30 \ldots\end{array}$ & $\begin{array}{l}275 \\
298 \\
321 \\
346 \\
371\end{array}$ & $\begin{array}{l}379 \\
412 \\
444 \\
479 \\
514\end{array}$ & $\begin{array}{l}483 \\
525 \\
567 \\
612 \\
658\end{array}$ & $\begin{array}{l}572 \\
622 \\
673 \\
727 \\
782\end{array}$ & $\begin{array}{l}660 \\
720 \\
779 \\
842 \\
905\end{array}$ & $\begin{array}{l}728 \\
793 \\
858 \\
928 \\
998\end{array}$ & $\begin{array}{r}795 \\
866 \\
938 \\
1,014 \\
1,090\end{array}$ & $\begin{array}{r}860 \\
938 \\
1,016 \\
1,102 \\
1,186\end{array}$ & $\begin{array}{r}924 \\
1,010 \\
1,095 \\
1,189 \\
1,283\end{array}$ & $\begin{array}{l}1,164 \\
1,270 \\
1,276\end{array}$ & $\begin{array}{l}-. . \\
1,234 \\
1,352 \\
1,469\end{array}$ \\
\hline
\end{tabular}

'Form class is the ratio between the diameter inside bark at 17 feet and diameter outside bark at 4.5 feet. 'Source: Tables for Estimating Board-foot Volume of Timber, by Clement Mesavage and James W. Girard. 
Deductions must be made for defects in the bole of the tree caused by rot, cracks, worm holes, poor shape and crook, or sweep. In defect-free trees, such as most pines, the lumber cut from trees scaled by the International $1 / 4$-inch rule will tally out very closely to the original estimates. Less precise estimates are given under the Doyle rule; a sawmill will cut out much more lumber from your logs than is measured by this scale, particularly from small trees and small logs. The Scribner rule is intermediate between the other two rules. Carefully consider the differences in these rules because the Doyle rule is widely used throughout the South. Be sure you know which scale prospective buyers are using for volume estimates.

Table 10. - Gross volume of tree, form class $80^{\prime}$ International $1 / 4$-inch rule ${ }^{2}$

\begin{tabular}{|c|c|c|c|c|c|c|c|c|c|c|c|}
\hline \multirow{2}{*}{$\begin{array}{l}\text { Tree } \\
\text { diam- } \\
\text { eter } \\
\text { (inches) }\end{array}$} & \multicolumn{11}{|c|}{$\begin{array}{c}\text { VOLUME (board feet) BY NUMBER OF } \\
\text { USABLE 16-FOOT LOGS }\end{array}$} \\
\hline & 1 & $11 / 2$ & 2 & $21 / 2$ & 3 & $31 / 2$ & 4 & $41 / 2$ & 5 & $51 / 2$ & 6 \\
\hline $\begin{array}{l}10 \\
11 \\
12 \\
13 \\
14 \\
15\end{array}$ & $\begin{array}{l}39 \\
49 \\
59 \\
71 \\
83 \\
98\end{array}$ & $\begin{array}{r}51 \\
64 \\
78 \\
96 \\
112 \\
132\end{array}$ & $\begin{array}{r}63 \\
80 \\
98 \\
120 \\
141 \\
166\end{array}$ & $\begin{array}{r}72 \\
92 \\
112 \\
138 \\
164 \\
194\end{array}$ & $\begin{array}{r}80 \\
104 \\
127 \\
156 \\
186 \\
221\end{array}$ & $\begin{array}{r}136 \\
168 \\
201 \\
240\end{array}$ & $\begin{array}{r}146 \\
181 \\
216 \\
260\end{array}$ & $\begin{array}{l}--- \\
--- \\
--- \\
--- \\
-- \\
---\end{array}$ & 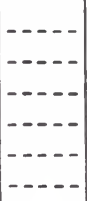 & 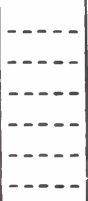 & 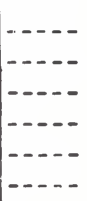 \\
\hline $\begin{array}{l}16 \ldots \ldots \\
17 \ldots \ldots \\
18 \ldots \ldots \\
18 \ldots \ldots \\
20 \ldots \ldots\end{array}$ & $\begin{array}{l}112 \\
128 \\
144 \\
162 \\
181\end{array}$ & $\begin{array}{l}151 \\
174 \\
196 \\
222 \\
248\end{array}$ & $\begin{array}{l}190 \\
219 \\
248 \\
281 \\
314\end{array}$ & $\begin{array}{l}223 \\
258 \\
292 \\
332 \\
370\end{array}$ & $\begin{array}{l}256 \\
296 \\
336 \\
382 \\
427\end{array}$ & $\begin{array}{l}280 \\
325 \\
369 \\
420 \\
470\end{array}$ & $\begin{array}{l}305 \\
354 \\
402 \\
457 \\
512\end{array}$ & 546 & 580 & & 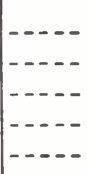 \\
\hline $\begin{array}{l}21 \ldots \ldots \\
22 \\
23 \\
24 \ldots \ldots \\
25 \ldots \ldots\end{array}$ & $\begin{array}{l}201 \\
221 \\
244 \\
266 \\
290\end{array}$ & $\begin{array}{l}276 \\
304 \\
336 \\
368 \\
402\end{array}$ & $\begin{array}{l}350 \\
387 \\
428 \\
469 \\
514\end{array}$ & $\begin{array}{l}414 \\
458 \\
507 \\
556 \\
610\end{array}$ & $\begin{array}{l}478 \\
528 \\
586 \\
644 \\
706\end{array}$ & $\begin{array}{l}526 \\
583 \\
646 \\
708 \\
779\end{array}$ & $\begin{array}{l}575 \\
638 \\
706 \\
773 \\
852\end{array}$ & $\begin{array}{l}616 \\
685 \\
761 \\
836 \\
922\end{array}$ & $\begin{array}{l}656 \\
732 \\
816 \\
899 \\
992\end{array}$ & & $\mid \begin{array}{l}-\cdots \\
-\ldots \\
-\cdots \\
-\cdots \\
-\cdots\end{array}$ \\
\hline $\begin{array}{l}26 \ldots \ldots \\
27 \\
28 \\
29 \\
29 \\
30 \ldots \ldots\end{array}$ & $\begin{array}{l}315 \\
341 \\
367 \\
396 \\
424\end{array}$ & $\begin{array}{l}436 \\
474 \\
510 \\
551 \\
591\end{array}$ & $\begin{array}{l}558 \\
606 \\
654 \\
706 \\
758\end{array}$ & $\begin{array}{l}662 \\
721 \\
779 \\
842 \\
904\end{array}$ & $\begin{array}{r}767 \\
836 \\
904 \\
977 \\
1,050\end{array}$ & $\begin{array}{r}849 \\
925 \\
1,000 \\
1,080 \\
1,161\end{array}$ & $\begin{array}{r}931 \\
1,014 \\
1,096 \\
1,184 \\
1,272\end{array}$ & $\begin{array}{l}1,008 \\
1,100 \\
1,190 \\
1,289 \\
1,388\end{array}$ & $\begin{array}{l}1,086 \\
1,185 \\
1,284 \\
1,394 \\
1,503\end{array}$ & $\begin{array}{l}-\ldots \\
1,368 \\
1,491 \\
1,613\end{array}$ & \begin{tabular}{l}
$\ldots$ \\
\hdashline 1,453 \\
1,588 \\
1,723
\end{tabular} \\
\hline
\end{tabular}

'See footnote 1 in table 9.

'Source: Tables for Estimating Board-foot Volume of Timber, by Clement Mesavage and James W. Girard. 
Table 11 - Gross volume of tree, form class $75^{\prime}$, Doyle log rule

\begin{tabular}{|c|c|c|c|c|c|c|c|c|c|c|c|}
\hline \multirow{2}{*}{$\begin{array}{l}\text { Tree } \\
\text { diam- } \\
\text { eter } \\
\text { (inches) }\end{array}$} & \multicolumn{11}{|c|}{$\begin{array}{c}\text { VOLUME (board feet) BY NUMBER OF } \\
\text { USABLE 16-FOOT LOGS }\end{array}$} \\
\hline & 1 & $11 / 2$ & 2 & $21 / 2$ & 3 & $31 / 2$ & 4 & $41 / 2$ & 5 & $51 / 2$ & 6 \\
\hline $\begin{array}{l}10 \\
11 \\
12 \\
13 \\
14 \\
15\end{array}$ & $\begin{array}{l}12 \\
18 \\
25 \\
34 \\
42 \\
53\end{array}$ & $\begin{array}{l}14 \\
22 \\
31 \\
42 \\
54 \\
68\end{array}$ & $\begin{array}{l}16 \\
26 \\
37 \\
51 \\
65 \\
83\end{array}$ & $\begin{array}{l}40 \\
56 \\
72 \\
94\end{array}$ & $\begin{array}{r}44 \\
62 \\
80 \\
104\end{array}$ & 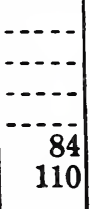 & $\begin{array}{r}0 \\
87 \\
117\end{array}$ & & 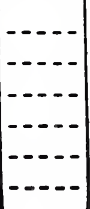 & & 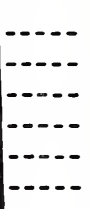 \\
\hline $\begin{array}{l}16 \\
17 \\
18 \\
18 \\
20 \ldots\end{array}$ & $\begin{array}{r}64 \\
77 \\
90 \\
106 \\
121\end{array}$ & $\begin{array}{r}82 \\
100 \\
118 \\
140 \\
160\end{array}$ & $\begin{array}{l}101 \\
124 \\
146 \\
173 \\
200\end{array}$ & $\begin{array}{l}115 \\
142 \\
168 \\
200 \\
231\end{array}$ & $\begin{array}{l}129 \\
159 \\
189 \\
226 \\
262\end{array}$ & $\begin{array}{l}138 \\
170 \\
203 \\
243 \\
282\end{array}$ & $\begin{array}{l}147 \\
182 \\
217 \\
260 \\
303\end{array}$ & $31 \bar{g}$ & \begin{tabular}{l}
$-\cdots$ \\
\hdashline..- \\
\hdashline.-- \\
\hdashline 335
\end{tabular} & & - \\
\hline $\begin{array}{l}21 \ldots \ldots \\
22 \ldots \ldots \\
23 \ldots \ldots \\
24 \ldots \\
25 \ldots\end{array}$ & $\begin{array}{l}138 \\
156 \\
176 \\
196 \\
218\end{array}$ & $\begin{array}{l}184 \\
209 \\
237 \\
264 \\
295\end{array}$ & $\begin{array}{l}231 \\
262 \\
298 \\
333 \\
372\end{array}$ & $\begin{array}{l}268 \\
304 \\
347 \\
389 \\
436\end{array}$ & $\begin{array}{l}304 \\
346 \\
396 \\
445 \\
499\end{array}$ & $\begin{array}{l}329 \\
376 \\
429 \\
481 \\
542\end{array}$ & $\begin{array}{l}354 \\
406 \\
462 \\
517 \\
586\end{array}$ & $\begin{array}{l}374 \\
430 \\
493 \\
554 \\
628\end{array}$ & $\begin{array}{l}395 \\
455 \\
524 \\
592 \\
670\end{array}$ & 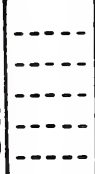 & 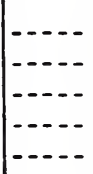 \\
\hline $\begin{array}{l}26 \\
27 \\
27 \\
28 \ldots \ldots \\
29 \\
30 \ldots \ldots\end{array}$ & $\begin{array}{l}240 \\
264 \\
289 \\
316 \\
342\end{array}$ & $\begin{array}{l}326 \\
360 \\
394 \\
432 \\
468\end{array}$ & $\begin{array}{l}412 \\
456 \\
499 \\
547 \\
595\end{array}$ & $\begin{array}{l}482 \\
535 \\
588 \\
644 \\
701\end{array}$ & $\begin{array}{l}553 \\
614 \\
676 \\
742 \\
807\end{array}$ & $\begin{array}{l}604 \\
670 \\
738 \\
810 \\
882\end{array}$ & $\begin{array}{l}654 \\
726 \\
799 \\
878 \\
956\end{array}$ & $\begin{array}{r}702 \\
781 \\
862 \\
849 \\
1,036\end{array}$ & $\begin{array}{r}749 \\
836 \\
924 \\
1,020 \\
1,117\end{array}$ & $\begin{array}{r}\ldots 880 \\
1,087 \\
1,195\end{array}$ & \begin{tabular}{l}
$\cdots$ \\
\hdashline 1,036 \\
1,154 \\
1,273
\end{tabular} \\
\hline
\end{tabular}

'See footnote 1 in table 9.

'Source: Tables for Estimating Board-foot Volume of Timber, by Clement Mesavage and James W. Girard. 
Table 12. - Gross volume of tree, form class $80^{\prime}$ Doyle log rule ${ }^{2}$

\begin{tabular}{|c|c|c|c|c|c|c|c|c|c|c|c|}
\hline \multirow{2}{*}{$\begin{array}{l}\text { Treo } \\
\text { diam- } \\
\text { eter } \\
\text { (inches) }\end{array}$} & \multicolumn{11}{|c|}{$\begin{array}{c}\text { VOLUME (board foet) BY NUMBER OF } \\
\text { USABLE 16-FOOT LOGB }\end{array}$} \\
\hline & 1 & $13 / 2$ & 2 & $21 / 2$ & 3 & $31 / 2$ & 4 & $41 / 2$ & 5 & $51 / 2$ & 6 \\
\hline $\begin{array}{l}10 \\
11 \\
12 \\
13 \\
14 \\
15\end{array}$ & $\begin{array}{l}16 \\
24 \\
31 \\
42 \\
52 \\
64\end{array}$ & $\begin{array}{l}20 \\
30 \\
39 \\
53 \\
67 \\
84\end{array}$ & $\begin{array}{r}23 \\
35 \\
47 \\
64 \\
82 \\
104\end{array}$ & $\begin{array}{r}24 \\
38 \\
52 \\
72 \\
93 \\
118\end{array}$ & $\begin{array}{r}26 \\
42 \\
57 \\
80 \\
104 \\
132\end{array}$ & $\begin{array}{r}60 \\
84 \\
109 \\
141\end{array}$ & $\begin{array}{r}62 \\
88 \\
114 \\
150\end{array}$ & 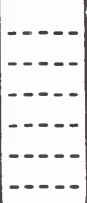 & 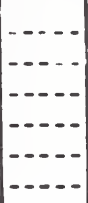 & 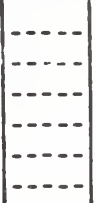 & 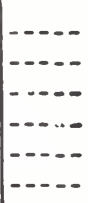 \\
\hline $\begin{array}{l}16 \ldots \ldots \\
17 \\
18 \\
18 \ldots \ldots \\
20 \ldots \ldots\end{array}$ & $\begin{array}{r}77 \\
92 \\
108 \\
126 \\
144\end{array}$ & $\begin{array}{l}101 \\
122 \\
144 \\
168 \\
193\end{array}$ & $\begin{array}{l}125 \\
152 \\
179 \\
210 \\
242\end{array}$ & $\begin{array}{l}143 \\
175 \\
206 \\
244 \\
282\end{array}$ & $\begin{array}{l}161 \\
198 \\
234 \\
278 \\
321\end{array}$ & $\begin{array}{l}174 \\
214 \\
254 \\
301 \\
348\end{array}$ & $\begin{array}{l}186 \\
230 \\
273 \\
324 \\
374\end{array}$ & - & $\mid \begin{array}{r}-\cdots \\
\hdashline-1 \\
\hdashline-17\end{array}$ & 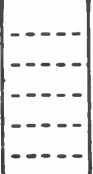 & 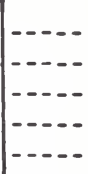 \\
\hline $\begin{array}{l}21 \ldots \ldots \\
22 \\
23 \\
24 \\
25\end{array}$ & $\begin{array}{l}164 \\
185 \\
208 \\
231 \\
256\end{array}$ & $\begin{array}{l}221 \\
250 \\
282 \\
314 \\
350\end{array}$ & $\begin{array}{l}278 \\
315 \\
356 \\
397 \\
443\end{array}$ & $\begin{array}{l}324 \\
368 \\
417 \\
466 \\
522\end{array}$ & $\begin{array}{l}370 \\
420 \\
478 \\
536 \\
600\end{array}$ & $\begin{array}{l}403 \\
458 \\
521 \\
583 \\
655\end{array}$ & $\begin{array}{l}436 \\
497 \\
564 \\
630 \\
710\end{array}$ & $\begin{array}{l}462 \\
529 \\
604 \\
678 \\
764\end{array}$ & $\begin{array}{l}489 \\
561 \\
643 \\
725 \\
818\end{array}$ & 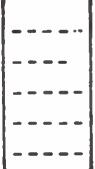 & 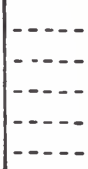 \\
\hline $\begin{array}{l}26 \ldots \ldots \\
27 \\
28 \\
29 \\
30 \ldots \ldots \ldots\end{array}$ & $\begin{array}{l}282 \\
310 \\
339 \\
370 \\
400\end{array}$ & $\begin{array}{l}386 \\
425 \\
466 \\
509 \\
552\end{array}$ & $\begin{array}{l}489 \\
540 \\
592 \\
648 \\
703\end{array}$ & $\begin{array}{l}576 \\
638 \\
700 \\
766 \\
832\end{array}$ & $\begin{array}{l}663 \\
735 \\
807 \\
884 \\
961\end{array}$ & $\begin{array}{r}727 \\
806 \\
885 \\
970 \\
1,055\end{array}$ & $\begin{array}{r}791 \\
877 \\
363 \\
1,056 \\
1,149\end{array}$ & $\begin{array}{r}852 \\
946 \\
1,040 \\
1,144 \\
1,248\end{array}$ & $\begin{array}{r}912 \\
1,015 \\
1,118 \\
1,232 \\
1,346\end{array}$ & $\mid$\begin{tabular}{l}
$-\ldots-$ \\
\hdashline 1,188 \\
1,315 \\
1,442
\end{tabular} & $\begin{array}{l}1,258 \\
1,398 \\
1,537\end{array}$ \\
\hline
\end{tabular}

'See footnote 1 in table 9.

'Source: Tables for Estimating Board-foot Volume of Timber, by Clement Mesavage and James W. Girard. 
Table 13. - Gross volume of tree, form class $75^{\prime}$ Scribner log rule ${ }^{2}$

\begin{tabular}{|c|c|c|c|c|c|c|c|c|c|c|c|}
\hline \multirow{2}{*}{$\begin{array}{l}\text { Tree } \\
\text { diam- } \\
\text { eter } \\
\text { (inches) }\end{array}$} & \multicolumn{11}{|c|}{$\begin{array}{c}\text { VOLUME (board feet) BY NUMBER OF } \\
\text { USABLE 16-FOOT LOGS }\end{array}$} \\
\hline & 1 & $11 / 2$ & 2 & $21 / 2$ & 3 & $31 / 2$ & 4 & $41 / 2$ & 5 & $51 / 2$ & 6 \\
\hline $\begin{array}{l}10 \\
11 \\
12 \\
13 \\
14 \\
15\end{array}$ & $\begin{array}{l}25 \\
34 \\
42 \\
52 \\
63 \\
74\end{array}$ & $\begin{array}{l}32 \\
43 \\
54 \\
68 \\
82 \\
98\end{array}$ & $\begin{array}{r}38 \\
52 \\
66 \\
84 \\
102 \\
122\end{array}$ & $\begin{array}{r}-74 \\
96 \\
116 \\
141\end{array}$ & $\begin{array}{r}83 \\
107 \\
131 \\
160\end{array}$ & $\begin{array}{l}140 \\
172\end{array}$ & \begin{tabular}{r}
$-\cdots$ \\
$-\cdots$ \\
\hdashline.-- \\
\hdashline 148 \\
$-\cdots$
\end{tabular} & $\begin{array}{c}--- \\
--- \\
--- \\
---\end{array}$ & $\mid \begin{array}{c}---- \\
-\cdots- \\
-\cdots- \\
-\cdots-\end{array}$ & & \\
\hline $\begin{array}{l}16 \ldots \\
17 \ldots \ldots \\
18 \ldots \\
19 \ldots \\
20 \ldots\end{array}$ & \begin{tabular}{r|r}
86 \\
100 \\
113 \\
128 \\
144
\end{tabular} & $\begin{array}{l}114 \\
133 \\
152 \\
173 \\
195\end{array}$ & $\begin{array}{l}142 \\
166 \\
191 \\
218 \\
246\end{array}$ & $\begin{array}{l}165 \\
193 \\
222 \\
255 \\
288\end{array}$ & $\begin{array}{l}188 \\
220 \\
253 \\
292 \\
331\end{array}$ & $\begin{array}{l}204 \\
240 \\
276 \\
318 \\
360\end{array}$ & $\begin{array}{l}220 \\
260 \\
299 \\
344 \\
389\end{array}$ & 412 & 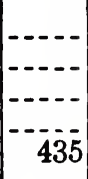 & & \\
\hline $\begin{array}{l}21 \ldots \\
22 \ldots \ldots \\
23 \ldots \\
24 \ldots \\
25 \ldots\end{array}$ & $\begin{array}{l}160 \\
177 \\
196 \\
216 \\
236\end{array}$ & $\begin{array}{l}218 \\
242 \\
268 \\
296 \\
324\end{array}$ & $\begin{array}{l}276 \\
306 \\
340 \\
375 \\
412\end{array}$ & $\begin{array}{l}324 \\
360 \\
401 \\
442 \\
486\end{array}$ & $\begin{array}{l}372 \\
413 \\
462 \\
510 \\
560\end{array}$ & $\begin{array}{l}406 \\
453 \\
505 \\
556 \\
615\end{array}$ & $\begin{array}{l}441 \\
493 \\
548 \\
603 \\
670\end{array}$ & $\begin{array}{l}470 \\
526 \\
588 \\
650 \\
722\end{array}$ & $\begin{array}{l}498 \\
560 \\
629 \\
698 \\
774\end{array}$ & & \\
\hline $\begin{array}{l}26 .- \\
27-- \\
28 .- \\
29 .-\end{array}$ & $\begin{array}{l}257 \\
280 \\
302 \\
326 \\
351\end{array}$ & $\begin{array}{l}352 \\
385 \\
416 \\
451 \\
486\end{array}$ & $\begin{array}{l}448 \\
490 \\
531 \\
576 \\
620\end{array}$ & $\begin{array}{l}530 \\
580 \\
629 \\
682 \\
736\end{array}$ & $\begin{array}{l}611 \\
669 \\
727 \\
7839 \\
851\end{array}$ & $\begin{array}{l}674 \\
736 \\
800 \\
868 \\
936\end{array}$ & $\begin{array}{r}736 \\
804 \\
872 \\
946 \\
1,021\end{array}$ & $\begin{array}{r}794 \\
869 \\
944 \\
1,027 \\
1,110\end{array}$ & $\begin{array}{r}851 \\
934 \\
1,017 \\
1,108 \\
1,199\end{array}$ & \begin{tabular}{l}
$\cdots$ \\
\hdashline 1,080 \\
1,183 \\
1,286
\end{tabular} & $\begin{array}{l}\overline{1}, 144 \\
1,258 \\
1,373\end{array}$ \\
\hline
\end{tabular}

'See footnote 1 in table 9.

'Source: Tables for Estimating Board-foot Volume of Timber, by Clement Mesavage and James W. Girard 
Table 14. - Gross volume of tree, form class 80', Scribner log rule ${ }^{2}$

\begin{tabular}{|c|c|c|c|c|c|c|c|c|c|c|c|}
\hline \multirow{2}{*}{$\begin{array}{l}\text { Treo } \\
\text { diam- } \\
\text { eter } \\
\text { (inches) }\end{array}$} & \multicolumn{11}{|c|}{$\begin{array}{c}\text { VOLUME (board feet) BY NUMBER OF } \\
\text { USABLE 16-FOOT LOGS }\end{array}$} \\
\hline & 1 & $11 / 2$ & 2 & $21 / 2$ & 3 & $31 / 2$ & 4 & $41 / 2$ & 5 & $51 \frac{1}{2}$ & 6 \\
\hline 10 & $\begin{array}{l}30 \\
40 \\
50 \\
62 \\
74 \\
88\end{array}$ & $\begin{array}{r}38 \\
52 \\
65 \\
82 \\
98 \\
117\end{array}$ & $\begin{array}{r}47 \\
64 \\
80 \\
101 \\
122 \\
146\end{array}$ & $\begin{array}{r}52 \\
72 \\
91 \\
116 \\
140 \\
169\end{array}$ & $\begin{array}{r}57 \\
80 \\
102 \\
130 \\
158 \\
192\end{array}$ & $\begin{array}{r}-108 \\
139 \\
170 \\
208\end{array}$ & $\begin{array}{l}115 \\
148 \\
181 \\
223\end{array}$ & & 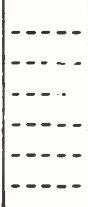 & & \\
\hline $\begin{array}{l}16 \ldots \ldots \\
17 \ldots \ldots \ldots \\
18 \ldots \ldots \\
19 \\
20 \ldots \ldots\end{array}$ & $\begin{array}{l}101 \\
116 \\
131 \\
148 \\
166\end{array}$ & $\begin{array}{l}136 \\
156 \\
178 \\
202 \\
226\end{array}$ & $\begin{array}{l}170 \\
197 \\
224 \\
256 \\
287\end{array}$ & $\begin{array}{l}198 \\
230 \\
263 \\
300 \\
338\end{array}$ & $\begin{array}{l}226 \\
264 \\
302 \\
345 \\
388\end{array}$ & $\begin{array}{l}246 \\
288 \\
330 \\
378 \\
426\end{array}$ & $\begin{array}{l}265 \\
312 \\
359 \\
411 \\
463\end{array}$ & 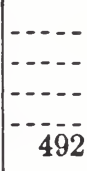 & $\mid$\begin{tabular}{l}
..- \\
$-\cdots$ \\
\hdashline- \\
$-\overline{5} 22$
\end{tabular} & & \\
\hline $\begin{array}{l}21 \ldots \ldots \\
22 \ldots \ldots \\
23 \ldots \ldots \\
24 \ldots \ldots \\
25 \ldots \ldots\end{array}$ & $\begin{array}{l}185 \\
204 \\
226 \\
248 \\
272\end{array}$ & $\begin{array}{l}254 \\
280 \\
311 \\
342 \\
376\end{array}$ & $\begin{array}{l}322 \\
357 \\
396 \\
435 \\
479\end{array}$ & $\begin{array}{l}379 \\
420 \\
468 \\
515 \\
568\end{array}$ & $\begin{array}{l}436 \\
484 \\
540 \\
595 \\
656\end{array}$ & $\begin{array}{l}480 \\
534 \\
594 \\
654 \\
722\end{array}$ & $\begin{array}{l}523 \\
583 \\
648 \\
712 \\
788\end{array}$ & $\begin{array}{l}558 \\
624 \\
697 \\
770 \\
852\end{array}$ & $\begin{array}{l}594 \\
666 \\
746 \\
827 \\
917\end{array}$ & & \\
\hline $\begin{array}{l}26 \ldots \ldots \\
27 \ldots \ldots \\
28 \ldots \ldots \\
29 \ldots \ldots \\
30 \ldots \ldots\end{array}$ & $\begin{array}{l}296 \\
322 \\
348 \\
376 \\
403\end{array}$ & $\begin{array}{l}410 \\
446 \\
482 \\
522 \\
560\end{array}$ & $\begin{array}{l}523 \\
570 \\
617 \\
667 \\
717\end{array}$ & $\begin{array}{l}620 \\
677 \\
734 \\
794 \\
854\end{array}$ & $\begin{array}{l}716 \\
784 \\
851 \\
921 \\
991\end{array}$ & $\begin{array}{r}790 \\
865 \\
940 \\
1,017 \\
1,094\end{array}$ & $\begin{array}{r}865 \\
946 \\
1,028 \\
1,113 \\
1,198\end{array}$ & $\begin{array}{r}936 \\
1,025 \\
1,114 \\
1,210 \\
1,306\end{array}$ & $\begin{array}{l}1,007 \\
1,104 \\
1,200 \\
1,306 \\
1,413\end{array}$ & $\begin{array}{l}1,278 \\
1,396 \\
1,515\end{array}$ & $\begin{array}{l}1,357 \\
1,487 \\
1,617\end{array}$ \\
\hline
\end{tabular}

'See footnote 1 in table 9.

'Source: Tables for Estimating Board-foot Volume of Timber, by Clement Mesavage and James W. Girard. 
The contents of 16-foot logs, in board feet, are given for the three rules in tables 15,16 , and 17 . These tables àre based upon the average diameter in inches inside the bark at the small end of the log. Note that the three rules give about the same scale only for the very largest logs - sizes which are no longer common.

Table 15. - Scale of 16-foot logs to nearest board foot' from International 1/4-inch rule, 1/4-inch kerf $^{2}$

\begin{tabular}{|c|c|c|c|c|c|c|c|c|c|c|}
\hline $\begin{array}{l}\text { D.i.b. } \\
\text { (inches) }\end{array}$ & 0 & .1 & .2 & .3 & .4 & .5 & .6 & .7 & .8 & .9 \\
\hline $\begin{array}{r}6 \ldots \ldots \\
7 \\
8 \ldots \ldots \\
9 \\
10 \ldots \ldots\end{array}$ & $\begin{array}{l}19 \\
28 \\
39 \\
51 \\
65\end{array}$ & $\begin{array}{l}20 \\
29 \\
40 \\
52 \\
66\end{array}$ & $\begin{array}{l}21 \\
30 \\
41 \\
54 \\
68\end{array}$ & $\begin{array}{l}22 \\
31 \\
42 \\
55 \\
69\end{array}$ & $\begin{array}{l}23 \\
32 \\
43 \\
56 \\
71\end{array}$ & $\begin{array}{l}23 \\
33 \\
45 \\
58 \\
72\end{array}$ & $\begin{array}{l}24 \\
34 \\
46 \\
59 \\
74\end{array}$ & $\begin{array}{l}25 \\
35 \\
47 \\
60 \\
75\end{array}$ & $\begin{array}{l}26 \\
36 \\
48 \\
62 \\
77\end{array}$ & $\begin{array}{l}27 \\
38 \\
50 \\
63 \\
78\end{array}$ \\
\hline $\begin{array}{l}11 \ldots \ldots \\
12 \ldots \ldots \\
13 \ldots \ldots \\
14 \ldots \ldots \\
15 \ldots \ldots\end{array}$ & $\begin{array}{r}80 \\
97 \\
115 \\
136 \\
157\end{array}$ & $\begin{array}{r}82 \\
99 \\
117 \\
138 \\
160\end{array}$ & $\begin{array}{r}83 \\
100 \\
119 \\
140 \\
162\end{array}$ & $\begin{array}{r}85 \\
102 \\
121 \\
142 \\
164\end{array}$ & $\begin{array}{r}87 \\
104 \\
123 \\
144 \\
166\end{array}$ & $\begin{array}{r}88 \\
106 \\
125 \\
146 \\
169\end{array}$ & $\begin{array}{r}80 \\
108 \\
127 \\
148 \\
171\end{array}$ & $\begin{array}{r}92 \\
110 \\
129 \\
151 \\
173\end{array}$ & $\begin{array}{r}93 \\
112 \\
131 \\
153 \\
176\end{array}$ & $\begin{array}{r}95 \\
114 \\
133 \\
155 \\
178\end{array}$ \\
\hline $\begin{array}{l}16 \ldots \ldots \\
17 \ldots \ldots \\
18 \ldots \ldots \\
19 \ldots \ldots \\
20 \ldots \ldots\end{array}$ & $\begin{array}{l}181 \\
205 \\
232 \\
260 \\
290\end{array}$ & $\begin{array}{l}183 \\
208 \\
235 \\
263 \\
293\end{array}$ & $\begin{array}{l}185 \\
211 \\
237 \\
266 \\
296\end{array}$ & $\begin{array}{l}188 \\
213 \\
240 \\
269 \\
299\end{array}$ & $\begin{array}{l}190 \\
216 \\
243 \\
272 \\
302\end{array}$ & $\begin{array}{l}193 \\
219 \\
246 \\
275 \\
305\end{array}$ & $\begin{array}{l}195 \\
221 \\
249 \\
278 \\
308\end{array}$ & $\begin{array}{l}198 \\
224 \\
251 \\
281 \\
311\end{array}$ & $\begin{array}{l}200 \\
227 \\
254 \\
284 \\
315\end{array}$ & $\begin{array}{l}203 \\
229 \\
257 \\
287 \\
318\end{array}$ \\
\hline $\begin{array}{l}21 \ldots \ldots \\
22 \ldots \ldots \\
23 \ldots \ldots \\
24 \ldots \ldots \\
25 \ldots \ldots\end{array}$ & $\begin{array}{l}321 \\
354 \\
388 \\
424 \\
462\end{array}$ & $\begin{array}{l}324 \\
357 \\
392 \\
428 \\
466\end{array}$ & $\begin{array}{l}327 \\
361 \\
395 \\
432 \\
470\end{array}$ & $\begin{array}{l}331 \\
364 \\
399 \\
435 \\
474\end{array}$ & $\begin{array}{l}334 \\
367 \\
403 \\
439 \\
478\end{array}$ & $\begin{array}{l}337 \\
371 \\
406 \\
443 \\
481\end{array}$ & $\begin{array}{l}341 \\
374 \\
410 \\
447 \\
485\end{array}$ & $\begin{array}{l}344 \\
378 \\
413 \\
451 \\
489\end{array}$ & $\begin{array}{l}347 \\
381 \\
417 \\
454 \\
493\end{array}$ & $\begin{array}{l}351 \\
385 \\
421 \\
458 \\
497\end{array}$ \\
\hline $\begin{array}{l}26 \ldots \ldots \\
27 \ldots \ldots \\
28 \ldots \ldots \\
29 \ldots \ldots \\
30 \ldots \ldots\end{array}$ & $\begin{array}{l}501 \\
542 \\
584 \\
628 \\
674\end{array}$ & $\begin{array}{l}505 \\
546 \\
589 \\
633 \\
679\end{array}$ & $\begin{array}{l}509 \\
550 \\
593 \\
637 \\
683\end{array}$ & $\begin{array}{l}513 \\
555 \\
598 \\
642 \\
688\end{array}$ & $\begin{array}{l}517 \\
559 \\
602 \\
647 \\
693\end{array}$ & $\begin{array}{l}521 \\
563 \\
606 \\
651 \\
697\end{array}$ & $\begin{array}{l}526 \\
567 \\
611 \\
656 \\
702\end{array}$ & $\begin{array}{l}530 \\
572 \\
615 \\
660 \\
707\end{array}$ & $\begin{array}{l}534 \\
576 \\
620 \\
665 \\
712\end{array}$ & $\begin{array}{l}538 \\
580 \\
624 \\
669 \\
716\end{array}$ \\
\hline $\begin{array}{l}31 \ldots \ldots \\
32 \ldots \ldots \\
33 \ldots \ldots \\
34 \ldots \ldots \\
35 \ldots \ldots\end{array}$ & $\begin{array}{l}721 \\
770 \\
820 \\
872 \\
926\end{array}$ & $\begin{array}{l}726 \\
775 \\
826 \\
878 \\
931\end{array}$ & $\begin{array}{l}731 \\
780 \\
831 \\
883 \\
937\end{array}$ & $\begin{array}{l}736 \\
785 \\
836 \\
888 \\
942\end{array}$ & $\begin{array}{l}741 \\
790 \\
841 \\
894 \\
948\end{array}$ & $\begin{array}{l}745 \\
795 \\
846 \\
899 \\
953\end{array}$ & $\begin{array}{l}750 \\
800 \\
851 \\
904 \\
959\end{array}$ & $\begin{array}{l}755 \\
805 \\
857 \\
910 \\
964\end{array}$ & $\begin{array}{l}760 \\
810 \\
862 \\
915 \\
970\end{array}$ & $\begin{array}{l}765 \\
815 \\
867 \\
921 \\
976\end{array}$ \\
\hline
\end{tabular}

'Computed from the formula $\mathrm{V}=0.796 \mathrm{D}-1.375 \mathrm{D}-1.230$.

'Source: Tables for Estimating Board-foot Volume of Timber, by Clement Mesavage and James W. Girard. 
Table 16. - Scale of 16-foot logs to nearest board foot' from Doyle rule $^{2}$

\begin{tabular}{|c|c|c|c|c|c|c|c|c|c|c|}
\hline $\begin{array}{c}\text { D.i.b. } \\
\text { (inches) }\end{array}$ & .0 & .1 & .2 & .3 & .4 & .5 & .6 & .7 & .8 & .8 \\
\hline $\begin{array}{l}5 \\
6 \\
6 \\
8 \\
8 \ldots \ldots \\
9\end{array}$ & $\begin{array}{r}1 \\
4 \\
9 \\
16 \\
25\end{array}$ & $\begin{array}{r}1 \\
4 \\
10 \\
17 \\
26\end{array}$ & $\begin{array}{r}1 \\
5 \\
10 \\
18 \\
27\end{array}$ & $\begin{array}{r}2 \\
5 \\
11 \\
18 \\
28\end{array}$ & $\begin{array}{r}2 \\
6 \\
12 \\
19 \\
29\end{array}$ & $\begin{array}{r}2 \\
6 \\
12 \\
20 \\
30\end{array}$ & $\begin{array}{r}3 \\
7 \\
13 \\
21 \\
31\end{array}$ & $\begin{array}{r}3 \\
7 \\
14 \\
22 \\
32\end{array}$ & $\begin{array}{r}3 \\
8 \\
14 \\
23 \\
34\end{array}$ & $\begin{array}{r}4 \\
8 \\
15 \\
24 \\
35\end{array}$ \\
\hline $\begin{array}{l}10 \ldots \ldots \\
11 \ldots \ldots \\
12 \ldots \ldots \\
13 \ldots \ldots \\
14 \ldots \ldots\end{array}$ & $\begin{array}{r}36 \\
49 \\
64 \\
81 \\
100\end{array}$ & $\begin{array}{r}37 \\
50 \\
66 \\
83 \\
102\end{array}$ & $\begin{array}{r}38 \\
52 \\
67 \\
85 \\
104\end{array}$ & $\begin{array}{r}40 \\
53 \\
69 \\
86 \\
106\end{array}$ & $\begin{array}{r}41 \\
55 \\
71 \\
88 \\
108\end{array}$ & $\begin{array}{r}42 \\
56 \\
72 \\
80 \\
110\end{array}$ & $\begin{array}{r}44 \\
58 \\
74 \\
92 \\
112\end{array}$ & $\begin{array}{r}45 \\
59 \\
76 \\
94 \\
114\end{array}$ & $\begin{array}{r}46 \\
61 \\
77 \\
96 \\
117\end{array}$ & $\begin{array}{r}48 \\
62 \\
79 \\
98 \\
119\end{array}$ \\
\hline $\begin{array}{l}15 \\
16 \\
17 \\
18 \ldots \ldots \\
18 \ldots \ldots\end{array}$ & $\begin{array}{l}121 \\
144 \\
169 \\
196 \\
225\end{array}$ & $\begin{array}{l}123 \\
146 \\
172 \\
199 \\
228\end{array}$ & $\begin{array}{l}125 \\
149 \\
174 \\
202 \\
231\end{array}$ & $\begin{array}{l}128 \\
151 \\
177 \\
204 \\
234\end{array}$ & $\begin{array}{l}130 \\
154 \\
180 \\
207 \\
237\end{array}$ & $\begin{array}{l}132 \\
156 \\
182 \\
210 \\
240\end{array}$ & $\begin{array}{l}135 \\
159 \\
185 \\
213 \\
243\end{array}$ & $\begin{array}{l}137 \\
161 \\
188 \\
216 \\
246\end{array}$ & $\begin{array}{l}139 \\
164 \\
190 \\
219 \\
250\end{array}$ & $\begin{array}{l}142 \\
166 \\
193 \\
222 \\
253\end{array}$ \\
\hline $\begin{array}{l}20 \ldots \\
21 \ldots \ldots \\
22 \ldots \ldots \\
23 \ldots \ldots \\
24 \ldots \ldots\end{array}$ & $\begin{array}{l}256 \\
289 \\
324 \\
361 \\
400\end{array}$ & $\begin{array}{l}259 \\
292 \\
328 \\
365 \\
404\end{array}$ & $\begin{array}{l}262 \\
296 \\
331 \\
369 \\
408\end{array}$ & $\begin{array}{l}266 \\
299 \\
335 \\
372 \\
412\end{array}$ & $\begin{array}{l}269 \\
303 \\
339 \\
376 \\
416\end{array}$ & $\begin{array}{l}272 \\
306 \\
342 \\
380 \\
420\end{array}$ & $\begin{array}{l}276 \\
310 \\
346 \\
384 \\
424\end{array}$ & $\begin{array}{l}279 \\
313 \\
350 \\
388 \\
428\end{array}$ & $\begin{array}{l}282 \\
317 \\
353 \\
392 \\
433\end{array}$ & $\begin{array}{l}286 \\
320 \\
357 \\
396 \\
437\end{array}$ \\
\hline $\begin{array}{l}25 \ldots \\
26 \ldots \\
27 \\
28 \\
28\end{array}$ & $\begin{array}{l}441 \\
484 \\
529 \\
576 \\
625\end{array}$ & $\begin{array}{l}445 \\
488 \\
534 \\
581 \\
630\end{array}$ & $\begin{array}{l}449 \\
493 \\
538 \\
586 \\
635\end{array}$ & $\begin{array}{l}454 \\
497 \\
543 \\
590 \\
640\end{array}$ & $\begin{array}{l}458 \\
502 \\
548 \\
595 \\
645\end{array}$ & $\begin{array}{l}462 \\
506 \\
552 \\
600 \\
650\end{array}$ & $\begin{array}{l}467 \\
511 \\
557 \\
605 \\
655\end{array}$ & $\begin{array}{l}471 \\
515 \\
562 \\
610 \\
660\end{array}$ & $\begin{array}{l}475 \\
520 \\
566 \\
615 \\
666\end{array}$ & $\begin{array}{l}480 \\
524 \\
571 \\
620 \\
671\end{array}$ \\
\hline $\begin{array}{l}30 \\
31 \\
32 \\
32 \\
33 \ldots \ldots \\
34\end{array}$ & $\begin{array}{l}676 \\
729 \\
784 \\
841 \\
900\end{array}$ & $\begin{array}{l}681 \\
734 \\
790 \\
847 \\
906\end{array}$ & $\begin{array}{l}686 \\
740 \\
795 \\
853 \\
912\end{array}$ & $\begin{array}{l}692 \\
745 \\
801 \\
858 \\
918\end{array}$ & $\begin{array}{l}697 \\
751 \\
807 \\
864 \\
924\end{array}$ & $\begin{array}{l}702 \\
756 \\
812 \\
870 \\
930\end{array}$ & $\begin{array}{l}708 \\
762 \\
818 \\
876 \\
936\end{array}$ & $\begin{array}{l}713 \\
767 \\
824 \\
882 \\
942\end{array}$ & $\begin{array}{l}718 \\
773 \\
829 \\
888 \\
949\end{array}$ & $\begin{array}{l}724 \\
778 \\
835 \\
894 \\
955\end{array}$ \\
\hline
\end{tabular}

'Computed from formula: $\frac{(\mathrm{D}-4)^{2} \times \mathrm{L}}{16}$.

'Source: Tables for Estimating Board-foot Volume of Timber. by Clement Mesavage and James W. Girard. 
Table 17 - Scale of 16-foot logs to nearest board foot ${ }^{1}$ from Scribner rule ${ }^{2}$

\begin{tabular}{|c|c|c|c|c|c|c|c|c|c|c|}
\hline $\begin{array}{l}\text { D.i.b. } \\
\text { (inches) }\end{array}$ & .0 & .1 & .2 & .3 & .4 & .5 & .6 & .7 & .8 & .8 \\
\hline $\begin{array}{r}6 \\
6 \\
8 \ldots \ldots \\
8 \ldots \ldots \\
8 \ldots \ldots\end{array}$ & $\begin{array}{l}12 \\
21 \\
30 \\
42 \\
55\end{array}$ & $\begin{array}{l}13 \\
22 \\
31 \\
43 \\
58\end{array}$ & $\begin{array}{l}14 \\
23 \\
32 \\
45 \\
58\end{array}$ & $\begin{array}{l}15 \\
24 \\
33 \\
46 \\
60\end{array}$ & $\begin{array}{l}16 \\
24 \\
34 \\
47 \\
61\end{array}$ & $\begin{array}{l}16 \\
25 \\
36 \\
48 \\
63\end{array}$ & $\begin{array}{l}17 \\
26 \\
37 \\
50 \\
64\end{array}$ & $\begin{array}{l}18 \\
27 \\
38 \\
51 \\
66\end{array}$ & $\begin{array}{l}19 \\
28 \\
39 \\
52 \\
67\end{array}$ & $\begin{array}{l}20 \\
29 \\
41 \\
54 \\
69\end{array}$ \\
\hline $\begin{array}{l}11 \\
12 \\
13 \\
14 \\
15\end{array}$ & $\begin{array}{r}70 \\
86 \\
104 \\
123 \\
144\end{array}$ & $\begin{array}{r}72 \\
88 \\
106 \\
125 \\
146\end{array}$ & $\begin{array}{r}74 \\
90 \\
108 \\
127 \\
148\end{array}$ & $\begin{array}{r}75 \\
91 \\
110 \\
129 \\
150\end{array}$ & $\begin{array}{r}77 \\
93 \\
111 \\
131 \\
153\end{array}$ & $\begin{array}{r}78 \\
95 \\
113 \\
133 \\
155\end{array}$ & $\begin{array}{r}80 \\
97 \\
115 \\
135 \\
157\end{array}$ & $\begin{array}{r}81 \\
99 \\
117 \\
137 \\
159\end{array}$ & $\begin{array}{r}83 \\
101 \\
119 \\
140 \\
161\end{array}$ & $\begin{array}{r}84 \\
102 \\
121 \\
142 \\
164\end{array}$ \\
\hline $\begin{array}{l}16 \ldots \\
17 \ldots \ldots \\
18 \ldots \\
18 \ldots \\
20 \ldots \ldots\end{array}$ & $\begin{array}{l}166 \\
180 \\
216 \\
243 \\
272\end{array}$ & $\begin{array}{l}168 \\
191 \\
218 \\
245 \\
275\end{array}$ & $\begin{array}{l}171 \\
194 \\
221 \\
248 \\
278\end{array}$ & $\begin{array}{l}173 \\
196 \\
224 \\
251 \\
281\end{array}$ & $\begin{array}{l}175 \\
199 \\
227 \\
254 \\
284\end{array}$ & $\begin{array}{l}177 \\
202 \\
229 \\
257 \\
287\end{array}$ & $\begin{array}{l}180 \\
204 \\
231 \\
260 \\
290\end{array}$ & $\begin{array}{l}182 \\
207 \\
234 \\
263 \\
293\end{array}$ & $\begin{array}{l}185 \\
210 \\
237 \\
266 \\
296\end{array}$ & $\begin{array}{l}187 \\
213 \\
240 \\
269 \\
299\end{array}$ \\
\hline $\begin{array}{l}21 \\
22 \\
23 \\
24 \\
24 \ldots\end{array}$ & $\begin{array}{l}302 \\
334 \\
368 \\
403 \\
440\end{array}$ & $\begin{array}{l}305 \\
337 \\
372 \\
406 \\
444\end{array}$ & $\begin{array}{l}308 \\
340 \\
375 \\
410 \\
448\end{array}$ & $\begin{array}{l}311 \\
344 \\
379 \\
414 \\
452\end{array}$ & $\begin{array}{l}314 \\
348 \\
382 \\
418 \\
456\end{array}$ & $\begin{array}{l}317 \\
351 \\
386 \\
422 \\
460\end{array}$ & $\begin{array}{l}320 \\
354 \\
390 \\
426 \\
464\end{array}$ & $\begin{array}{l}323 \\
358 \\
394 \\
429 \\
468\end{array}$ & $\begin{array}{l}327 \\
361 \\
397 \\
432 \\
472\end{array}$ & $\begin{array}{l}330 \\
365 \\
400 \\
436 \\
475\end{array}$ \\
\hline $\begin{array}{l}26 \\
27 \\
28 \\
29 \\
30 \ldots\end{array}$ & $\begin{array}{l}478 \\
518 \\
559 \\
602 \\
647\end{array}$ & $\begin{array}{l}482 \\
522 \\
563 \\
606 \\
651\end{array}$ & $\begin{array}{l}486 \\
526 \\
567 \\
611 \\
656\end{array}$ & $\begin{array}{l}490 \\
530 \\
571 \\
615 \\
660\end{array}$ & $\begin{array}{l}494 \\
534 \\
575 \\
620 \\
665\end{array}$ & $\begin{array}{l}498 \\
538 \\
579 \\
624 \\
669\end{array}$ & $\begin{array}{l}502 \\
542 \\
583 \\
629 \\
674\end{array}$ & $\begin{array}{l}506 \\
546 \\
587 \\
633 \\
678\end{array}$ & $\begin{array}{l}510 \\
550 \\
592 \\
638 \\
683\end{array}$ & $\begin{array}{l}514 \\
554 \\
597 \\
642 \\
688\end{array}$ \\
\hline $\begin{array}{l}31 \ldots \ldots \\
32 \ldots \ldots \\
33 \\
34 \ldots \ldots \\
35 \ldots \ldots\end{array}$ & $\begin{array}{l}693 \\
741 \\
790 \\
841 \\
894\end{array}$ & $\begin{array}{l}698 \\
746 \\
795 \\
846 \\
900\end{array}$ & $\begin{array}{l}703 \\
751 \\
800 \\
851 \\
905\end{array}$ & $\begin{array}{l}708 \\
756 \\
805 \\
856 \\
910\end{array}$ & $\begin{array}{l}712 \\
761 \\
810 \\
862 \\
915\end{array}$ & $\begin{array}{l}717 \\
766 \\
815 \\
867 \\
921\end{array}$ & $\begin{array}{l}722 \\
770 \\
820 \\
872 \\
926\end{array}$ & $\begin{array}{l}726 \\
775 \\
825 \\
877 \\
931\end{array}$ & $\begin{array}{l}731 \\
780 \\
830 \\
883 \\
937\end{array}$ & $\begin{array}{l}736 \\
785 \\
835 \\
888 \\
942\end{array}$ \\
\hline
\end{tabular}

'Computed from formula $\mathrm{V}=0.79 \mathrm{D}^{2}-2 \mathrm{D}-4$.

'Source: Tables for Estimating Board-foot Volume of Timber, by Clement Mesavage and James W. Girard. 
Cubic-volume tables, based upon the total tree height and the diameter at breast height, are given in tables 18 and 19 for estimating pulpwood volumes. These tables can be converted to cords by dividing by 75 for pine, and 66 for hardwood. Some buyers now purchase pulpwood using cunits (100 cubic feet) rather than cords as the unit of volume. Use table 18 for hardwoods and for pine 20 years and younger that has not been thinned. Use table 19 for older pine and for pine that has been thinned at least once. The average weight of a cord of green, pine pulpwood is 5,200 pounds.

Sell large, high-grade (defect- and knot-free) logs for veneer (hardwood) or plywood (pine) whenever possible because these products bring the highest prices. Pine plywood plants will

Table 18. - Merchantable cubic foot volume using total tree height (Form Class 70 - 74)'

\begin{tabular}{|c|c|c|c|c|c|c|c|c|}
\hline \multirow{2}{*}{$\begin{array}{c}\text { D.B.H. } \\
\text { (inches) }\end{array}$} & \multicolumn{7}{|c|}{ Total tree height (feet) } \\
\cline { 2 - 8 } & 30 & 40 & 50 & 60 & 70 & 80 & 90 & 100 \\
\hline 5 & 1.47 & 1.86 & 2.14 & 2.42 & & & & \\
6 & 2.32 & 2.84 & 3.29 & 3.66 & 4.27 & & & \\
7 & 3.31 & 3.98 & 4.66 & 5.23 & 5.90 & 6.48 & & \\
8 & 4.70 & 5.46 & 6.47 & 7.35 & 8.23 & 9.11 & & \\
9 & 5.87 & 6.90 & 8.08 & 9.25 & 10.28 & 11.31 & 12.34 & \\
10 & & 8.55 & 10.20 & 11.66 & 13.13 & 14.59 & 15.87 & \\
& & & & & & & & \\
11 & & 10.23 & 12.12 & 13.80 & 15.48 & 17.16 & 18.64 & 20.31 \\
12 & & 12.25 & 14.52 & 16.53 & 18.80 & 20.56 & 22.83 & 24.85 \\
13 & & 14.75 & 17.44 & 19.84 & 22.23 & 24.62 & 27.31 & 29.70 \\
14 & & & 20.33 & 23.12 & 25.92 & 28.71 & 31.85 & 34.64 \\
15 & & & 22.98 & 26.14 & 29.29 & 32.83 & 36.38 & 39.53 \\
16 & & & 26.01 & 29.54 & 33.08 & 37.06 & 41.04 & 44.57 \\
\hline
\end{tabular}

'Source: Bulletin 445, Form Class Volume Tables for Use in Southern Pine Pulpwood Timber Estimating, by Charles O. Minor 1950. Louisiana State University, Agricultural Experiment Station, Baton Rouge, LA $39 \mathrm{p}$.

${ }^{2}$ Diameter at breast height ( $4 \frac{1}{2}$ feet above ground). 
Table 19. - Merchantable cubic foot volume using total tree height (Form Classes 75 - 79) ${ }^{I}$

\begin{tabular}{|c|c|c|c|c|c|c|c|c|}
\hline \multirow{2}{*}{$\begin{array}{c}\text { D.B.H. } \\
\text { (inches) }\end{array}$} & \multicolumn{7}{|c|}{ Total tree height (feet) } \\
\cline { 2 - 9 } & 30 & 40 & 50 & 60 & 70 & 80 & 90 & 100 \\
\hline 5 & 1.62 & 2.06 & 2.37 & 2.69 & & & & \\
6 & 2.62 & 3.23 & 3.75 & 4.19 & 4.88 & & & \\
7 & 3.81 & 4.58 & 5.35 & 6.01 & 6.78 & 7.44 & & \\
8 & 5.20 & 6.05 & 7.19 & 8.18 & 9.17 & 10.17 & & \\
9 & 6.43 & 7.59 & 8.91 & 10.23 & 11.38 & 12.54 & 13.69 & \\
10 & & 9.59 & 11.48 & 13.16 & 14.84 & 16.52 & 17.99 & \\
& & & & & & & & \\
11 & & 11.64 & 13.85 & 15.81 & 17.77 & 19.73 & 21.69 & 23.40 \\
12 & & 13.80 & 16.42 & 18.74 & 21.36 & 23.40 & 26.02 & 28.35 \\
13 & & 16.44 & 19.50 & 22.22 & 24.94 & 27.66 & 30.72 & 33.44 \\
14 & & & 22.78 & 25.93 & 29.08 & 32.23 & 35.78 & 38.93 \\
15 & & & 26.36 & 30.06 & 33.75 & 37.91 & 42.07 & 45.76 \\
16 & & & 29.28 & 33.31 & 37.33 & 41.86 & 46.39 & 50.41 \\
\hline
\end{tabular}

'Source: Bulletin 445, Form Class Volume Tables for Use in Southern Pine Pulpwood Timber Estimating. by Charles O. Minor 1950. Louisiana State University, Agricultural Experiment Station, Baton Rouge, LA $39 \mathrm{p}$.

Diameter at breast height ( $4 \frac{1}{2}$ feet above ground).

take some surprisingly rough logs which they peel for core stock. In most areas, good markets exist for large, high-quality hardwood logs to be sawn into furniture stock. Low-quality hardwood logs are sawn into crossties, pallet stock, rough bridge timbers, and dunnage. Usually, no saw $\log$ is accepted under 8 feet in length. The minimum diameter for hardwood logs varies from 8 to 12 inches at the small end of the log. Chip-n-saw mills will take pine logs as small as 5 inches at the little end for manufacture into 2-inch dimension.

Straight, high-quality pines in the lower South are in good demand for poles and piling. Trees of suitable size and form usually bring more money per unit of board-foot volume as poles and piling than for sawlogs or other products. In some localities, pole-size hardwoods can be sold for river piling. 
Stumpage prices for pulpwood, particularly hardwood pulpwood, are generally low except in a few areas of intense competition. Under most conditions, only the small material and early thinnings should be marketed for pulpwood. In fact where good markets exist, 4-, 5- and sometimes 6-inch trees bring more as posts than for pulpwood. Pole-sized hardwoods within trucking distance of urban areas now bring more for fireplace wood than they do for pulpwood. All things considered, however, the marketing of small trees provides some early monetary return and helps to put the stand in good growing condition, but is not a very lucrative operation. Table 20 shows the comparative values for pulpwood and sawtimber.

In the past, emphasis was placed upon doing your own logging. Unless you are in a business in which trucks and tractors are used, it is not practical to invest in these vehicles. Equipment investment is too great to be practical if you do no more than cut a little firewood or a few fence posts.

A sample timber sale agreement is given in figure 16 . Because legal requirements vary by State, check to see if this sample contract is sufficient to protect your interests, in your State. To make a good sale, it is absolutely essential to know how much timber you have to sell. Do not hesitate to ask and pay for professional advice. Remember that you are an amateur dealing with professionals.

You have a choice of selling for a lump sum all designated timber, or selling for a price per thousand board feet, per cord or per ton. In selling for a lump sum, the price is determined on the basis of tree measurements made at the time the trees are marked for cutting. The chief advantages of selling on a lumpsum basis are that there is no question about the scale, the purchaser is not held up awaiting a scale of timber by the owner. and the purchaser uses most of the wood by taking poorer parts of the designated trees. Purchasers will accept this wood because they pay nothing for it.

When selling at a unit price, the owner must scale all the timber as it is cut or take the buyer's word for the scale. Some buyers of sawtimber who also operate sawmills prefer to buy on 
Table 20. - Alternative pulpwood and sawlog stumpage prices for loblolly pine.'

\begin{tabular}{|c|c|c|c|c|c|c|c|c|}
\hline \multirow[b]{2}{*}{ D.B.H. ${ }^{2}$} & \multirow{2}{*}{$\begin{array}{l}\text { Cords } \\
\text { per } \\
\text { Mbf }\end{array}$} & \multicolumn{7}{|c|}{ Dollars per Cord } \\
\hline & & 4 & 6 & 8 & 10 & 12 & 14 & 16 \\
\hline
\end{tabular}

International 1/4-inch Rule

$\begin{array}{rrrrrrrrr}8 & 4.0 & 16.00 & 24.00 & 32.00 & 40.00 & 48.00 & 56.00 & 64.00 \\ 9 & 3.7 & 14.80 & 22.20 & 29.60 & 37.00 & 44.40 & 51.80 & 59.20 \\ 10 & 3.4 & 13.60 & 20.40 & 27.20 & 34.00 & 40.80 & 47.60 & 54.40 \\ 11 & 3.2 & 12.80 & 19.20 & 25.60 & 32.00 & 38.40 & 44.80 & 51.20 \\ 12 & 2.9 & 11.60 & 17.40 & 23.20 & 29.00 & 34.80 & 40.60 & 46.40 \\ 13 & 2.7 & 10.80 & 16.20 & 21.60 & 27.00 & 32.40 & 37.80 & 43.20 \\ 14 & 2.5 & 10.00 & 15.00 & 20.00 & 25.00 & 30.00 & 35.00 & 40.00\end{array}$

Scribner Rule

$\begin{array}{rrrrrrrrr}8 & 4.4 & 17.60 & 26.40 & 35.20 & 44.00 & 52.80 & 61.60 & 70.40 \\ 9 & 4.1 & 16.40 & 24.60 & 32.80 & 41.00 & 49.20 & 57.40 & 65.60 \\ 10 & 3.8 & 15.20 & 22.80 & 30.40 & 38.00 & 45.60 & 53.20 & 60.80 \\ 11 & 3.6 & 14.40 & 21.60 & 28.80 & 36.00 & 43.20 & 50.40 & 57.60 \\ 12 & 3.4 & 13.60 & 20.40 & 27.20 & 34.00 & 40.80 & 47.60 & 54.40 \\ 13 & 3.2 & 12.80 & 19.20 & 25.60 & 32.00 & 38.40 & 44.80 & 51.20 \\ 14 & 3.0 & 12.00 & 18.00 & 24.00 & 30.00 & 36.00 & 42.00 & 48.00\end{array}$

Doyle Rule

$\begin{array}{rrrrrrrrr}8 & 6.8 & 27.20 & 40.80 & 54.40 & 68.00 & 81.20 & 95.20 & 108.80 \\ 9 & 6.8 & 27.20 & 40.80 & 54.40 & 68.00 & 81.20 & 95.20 & 108.80 \\ 10 & 6.8 & 27.20 & 40.80 & 54.40 & 68.00 & 81.20 & 95.20 & 108.80 \\ 11 & 6.3 & 25.20 & 37.80 & 50.40 & 63.00 & 75.60 & 88.20 & 100.80 \\ 12 & 6.2 & 24.80 & 37.20 & 49.60 & 62.00 & 74.40 & 86.80 & 99.20 \\ 13 & 5.2 & 20.80 & 31.20 & 41.60 & 52.00 & 62.40 & 72.80 & 83.20 \\ 14 & 4.5 & 18.00 & 27.00 & 36.00 & 45.00 & 54.00 & 63.00 & 72.00\end{array}$


mill scale (scale of lumber after sawing). You will benefit from this system only when you take all or part payment in the form of sawn lumber.

If you make frequent timber sales or plan to make a large sale, check with a tax expert for possible effects of the type of sale. Capital gains benefits could be lost if the wrong choice is made.

In some States, the extension service or the State forestry agency issue quarterly marketing reports that give the average and the range in stumpage prices for forest products in various areas of the State.

\section{Figure 16. - Sample timber sale agreement.}

(I or We) (Name of purchaser)

of

(Post Office Box, etc.)

(City, State)

hereinafter called the purchaser, agree to purchase

from

(Seller's name or names)

of

(Post Office Box or address)

hereinafter called the seller, the

(City, State)

designated timber from the area described below.

I. Description of the sale area:

Section

Township Range

II. Trees designated for cutting:

III. The purchaser agrees to the following:

1. To pay the seller for the designated timber the sum of $\$$ payable in advance of cutting as required by the seller. The seller makes no guarantee of volumes in this agreement.

2. To waive all claim to the above-described trees unless they are cut and removed on or before

(continued)

(date) 
Figure 16. - continued.

3. To pay the seller for any undesignated trees cut or injured through carelessness at the rate of three times the stumpage value. Damage to monuments or witness trees and reproduction will be held to a minimum.

4. To protect all operations from fire and to be held responsible for damages from fire resulting from negligence in the operations of the purchaser or of any agents.

5. To repair damage caused by logging to ditches, fences, bridges, roads, trails or other improvements damaged beyond ordinary wear and tear.

6. To be responsible for the entire work under this contract and for all tools, appliances and property of every description used in the removal of the designated timber. The purchaser shall specifically and distinctly assume all risks of damage or injury to persons or property resulting from any actions or operations under this contract or in connection with the work.

7. To assume all responsibility for the timber after award of the sale. The seller will continue to exercise all usual care for protection of the property during the sale period, but will not be responsible for any loss or damage from any cause whatsoever during that period.

8. To assign this agreement in whole or in part only with the written consent of the seller.

9. To permit the authorized representative of the owner to inspect harvesting as it is done. The presence of this representative will, in no case, relieve the purchaser of responsibility for performance of the terms of this contract.

10. To regenerate the area harvested by

(date)
either at cost or as part of the purchase price. , by

IV. The seller agrees to the following:

1. To guarantee title to the forest products covered by this agreement and to defend it against all claims at the seller's expense.

2. To grant freedom of entry and right-of-way to the purchaser and employees on and across the area covered by this agreement, and also other privileges usually extended to purchasers of stumpage which are not specifically covered, provided they do not conflict with specific provisions of this agreement.

Signed in duplicate this day 19 


\section{WHERE TO GO FOR HELP}

Most landowners need technical assistance. This help is available, but all too frequently only the best informed landowner uses it. Here are some of the people and agencies that stand ready to help.

Your State forestry agency employs professional foresters to serve as county or unit foresters. These men and women will provide forest management, insect and disease management, and marketing assistance to landowners. In some States, vendor services are provided to plant trees or to do timber stand improvement work at cost. Generally, a limit is put on the amount of time, timber marking help, or size of timber sale involved in any service given by the agency.

USDA's Soil Conservation Service will prepare a farm plan for cooperating landowners. This plan will identify those portions of the farm best suited for growing trees. The plan will include an aerial photograph and a soils map that will be of great value to the county forester in preparing a forest management plan for you.

Your State Extension Service at the land-grant colleges and universities employs foresters to provide information to you about forest management, use of wood products, stumpage prices, taxes, etc. These specialists closely follow the research underway at the forestry schools and help to get practical results into use in the field as soon as possible.

USDA's Agricultural Stabilization and Conservation Service, through the county offices offers landowners cost-sharing assistance under the Agricultural Conservation Program and the Forestry Incentives Program. Under these programs, you may receive as much as 75 percent of the cost (to a set maximum) of the installation of practices that will benefit the forest, wildlife, grazing, and water resources.

Industrial foresters are increasingly available to work with landowners who may be prospective suppliers of wood to the companies who employ these foresters. They often provide free 
timber marking and management plans. All that most of them ask in return is to have the "right of first refusal" when you have some timber to sell. They particularly like to work with owners of tracts of 200 acres or larger.

Consulting foresters are independent professionals who provide technical services for a fee. Many of them offer vender services for tree planting and timber stand improvement. They are particularly adept in handling timber sales. Absentee owners of large stands may find the consultant is very often the best source of help.

\section{REFERENCES}

\section{PART I}

The following publications have been used in preparing this booklet. Copies are available without charge from USDA Forest Service, Information Center, 1720 Peachtree Road, N.W., Suite 816, Atlanta, Ga. 30367. If you request copies, please mention the numbers shown after the titles.

Chemical Control of Vegetation in Southern Forests. 76-15.

Early Considerations in Pine Management. 75-6.

Firewood Worth Calculator. Unnumbered item; circular slide rule.

Growing Christmas Trees in the South. General Report SAGR 5.

Guide for Planting Southern Pines. 74-9.

How to Control White Pine Blister Rust in the Southern Appalachian Mountains. Forestry Bulletin SA-FB/P 23.

How to Identify and Control White Pine Root Decline. Forestry Bulletin SA-FB/P 6. 
How to Identify Fusiform Rust and and What to Do About It. Forestry Bulletin SA-FB/P 24.

How to Improve Forest Game Habitat. 74-11.

How to Save Your Fusiform Rust Infected Pines by Removing Cankers. Forestry Bulletin SA-FB/P 7.

Managing for Natural Regeneration. 74-14.

Managing for Poles and Piling. 75-19.

Managing Southern Pine Forests to Produce Forage for Beef Cattle. 76-22.

Many Landowners Pay Too Much Income Tax: Do You? General Report SA-GR 18.

The Need for Precommercial Thinning. 73-17.

Smoke from Forest and Other Open Burning. General Report SA-GR 23.

Thinning Pine Plantations in 1981 and After 71-22.

Tips on Hardwood Forest Management. 72-20.

Watershed Management for Small Landowners. 73-30.

Single free copies of the following publication are available from the address shown below. Copies are not available from the Forest Service.

How to Market Your Timber for More Money, by Alden C. Main and Robert H. Mills. Rev. 1980. Cooperative Extension Pub. No. 1805. Louisiana State University, Cooperative Extension Service, 265 Knapp Hall, Baton Rouge, La. 70803. 


\section{PART II}

We also used information from the following publications. Copies are no longer in print, but may be consulted at a library.

Forest Management Plan for Small Landowners, by H. L. Williston. 1974. Unnumbered forest management bulletin. USDA Forest Service, Southeastern Area, Atlanta, Ga. 6 pages.

Form Class Volume Tables for Use in Southern Pine Pulpwood Timber Estimating, by Charles O. Minor. 1950. Bull. No. 445, Louisiana State Univ. Agric. Exper. Station., Baton Rouge, La. 39 pages.

A Guide for Prescribed Fire in Southern Forests, by Hugh E. Mobley, et al. 1973. USDA Forest Service, Southeastern Area, Atlanta, Ga. 40 pages.

Guidelines for the Control of Insect and Mite Pests of Foods, Fibers, Feeds, Ornamentals, Livestock, Household, Forests and Forest Products, P. H. Schwartz and D. R. Hamel, Editors. 1980. Agriculture Handbook No. 571. USDA Agricultural Research Service and Forest Service, Washington, D. C. 796 pages.

Insects and Diseases of Trees of the South. 1972. USDA Forest Service, Southeastern Area, Atlanta, Ga. 88 pages.

Permanent Logging Roads for Better Woodlot Management, by Richard F. Haussman and Emerson W. Pruett. Third ed., 1978. USDA Forest Service, Northeastern Area, Broomall, Pa. 43 pages.

Pruning for Better Sawlogs, by Hamlin L. Williston. Southern Lumberman, December 1973, pages 129-130. 
Proceedings of the Workshop on Management of Southern Forests for Non-game Birds. 1978. General Technical Report SE-14. USDA Forest Service, Southeastern Forest Experiment Station, Asheville, N. C. 175 pages.

Response of Selected Woody Plants in the United States to Herbicides, by Rodney W. Bovey. 1978. Agriculture Handbook No. 493. USDA Agricultural Research Service, Washington, D. C. 101 pages.

Site Preparation: Why and How, by William E. Balmer, et al. 1976. Unnumbered forest management bulletin. USDA Forest Service, Southeastern Area, Atlanta, Ga. 8 pages.

Suggested Guidelines for Weed Control. 1980. Agriculture Handbook No. 565. USDA Agricultural Research Service, Washington, D. C. 330 pages.

Tables for Estimating Board-Foot Volume of Timber, by Clement Mesavage and James W. Girard, 1956, Unnumbered pub. USDA Forest Service. Washington, D. C. 94 pages.

Wildlife Versus Prescribed Fire in the Southern Environment, by Hugh E. Mobley and Ed. Kerr. 1973. Unnumbered bulletin. USDA Forest Service, Southeastern Area, Atlanta, Ga. 6 pages.

\section{GLOSSARY}

All-aged management - The management of a stand or tract to provide for trees of all or almost all age classes up to harvest age.

Artificial regeneration. - Reestablishing trees either by planting seedlings or sowing seed. 
Basal area. - The area, usually in square feet, of the cross section of a tree at breast height ( $41 / 2$ feet above ground).

Clear-cutting, commercial. - The cutting of all merchantable trees from an area. Often leaves a large number of unsalable trees.

Clear-cutting, silvicultural. - The cutting of all standing trees from an area before regeneration. This practice often combines a commercial clear-cut with a follow-up treatment to cut unmerchantable trees.

Crop tree. - Any tree selected to grow to final harvest or to a selected size.

D.B.H. (d.b.h.). - The diameter of a tree measured in inches at breast height ( $4 \frac{1}{2}$ feet above the ground).

Dominant. - An individual tree or species of tree with the crown (tops) in the upper layer of the tree canopy.

Dormant seedlings. - Seedlings that have temporarily ceased visible growth (sometimes called a resting stage) because of high or low temperature, moisture or other external causes.

Even-aged management. - Managing a stand or tract for trees of the same or nearly the same age. A large forest may have stands of several ages.

Firebreak. - An area used to slow or stop fires either by clearing to mineral soil or use of green or slow-burning vegetation.

Group selection. - removal of small groups of trees to regenerate the opening thus created.

Improvement cut. - Removal of less valuable, unhealthy, or less desirable trees. 
Intolerant species. - Trees that will not thrive in the shade of larger trees.

J-Root. - Seedling roots planted in a manner that forms a J-shaped configuration in the planting slit. Such seedlings may grow poorly or die.

L-Root - Seedling roots planted with roots forming an Lshaped configuration. Such seedlings may grow poorly or die.

Natural regeneration. - Regenerating a stand of trees using seed from trees either on-site or nearby, or sprout growth for some species of hardwoods.

Prescribed burning. - Using fire as a tool under carefully controlled conditions in forest management and protection.

Root collar. - The stem of a seedling at the ground line at the time of removal from the nursery.

Rotation. - The planned number of years between the regeneration of a stand and the final cut.

Selective cutting. - The periodic removal of individual or groups of trees to improve or regenerate a stand.

Shelterwood. - A system of cutting to develop a new crop of trees under a portion of the old stand which provides adequate seed and, in some cases, protection.

Site Index. - A measure of the productivity of a site as indicated by the height of the dominant trees in the stand at an arbitrarily chosen age (both 25 and 50 years are used in the South).

Stratified seed. - Seed that has been stored in a cool, moist condition before use. This storage practice hastens the germination of some species. 
Suppressed tree. - A tree that is not free to grow because of crown competition from above; as a result, the tree grows slowly.

Tolerant species. - A species of tree that has the ability to grow in the shade of, and in competition with, other trees. An intolerant species is unable to withstand this competition or grows poorly under the same conditions.

\section{CAUTION}

Pesticides used improperly can be injurious to man, animals, and plants. Follow the directions and heed all precautions on the labels.

Store pesticides in original containers under lock and key - out of the reach of children and animals - and away from food and feed.

Apply pesticides so that they do not endanger humans, livestock, crops, beneficial insects, fish, and wildlife. Do not apply pesticides when there is danger of drift, when honey bees or other pollinating insects are visiting plants, or in ways that may contaminate water or leave illegal residues.

Avoid prolonged inhalation of pesticide sprays or dusts; wear protective clothing and equipment if specified on the container.

If your hands become contaminated with a pesticide, do not eat or drink until you have washed them. In case a pesticide is swallowed or gets in the eyes, follow the first aid treatment given on the label, and get prompt medical attention. If a pesticide is spilled on your skin or clothing, remove clothing immediately and wash skin thoroughly.

Do not clean spray equipment or dump excess spray material near ponds, streams, or wells. Because it is difficult to remove all traces of herbicides from equipment, do not use the same equipment for insecticides or fungicides that you use for herbicides.

Dispose of empty pesticide containers promptly. Have them buried at a sanitary land-fill dump, or crush and bury them in a level, isolated place.

NOTE: Some States have restrictions on the use of certain pesticides. Check your State and local regulations. Also, because registrations of pesticides are under constant review by the U.S. Environmental Protection Agency, consult your State forestry agency, county agricultural agent or State extension specialist to be sure the intended use is still registered.

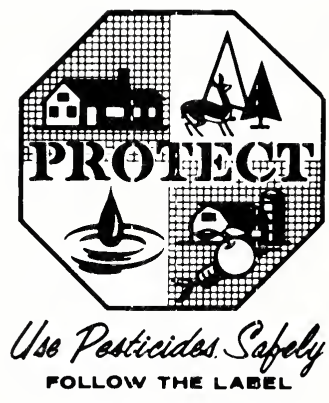

US DEPARTMENT OF AGRICUITURE 